\title{
AVALIAÇÃO DE PROTÓTIPOS DE SEMEADORAS EM COVA PARA SEMEADURA DIRETA DE MILHO
}

\author{
JUAN JOSÉ BONNIN ACOSTA \\ Engenheiro Agrônomo
}

Orientador: Prof. Dr. José Paulo Molin

Dissertação apresentada à Escola Superior de Agricultura "Luiz de Queiroz", Universidade de São Paulo, para a obtenção do título de Mestre em Agronomia, Área de Concentração: Máquinas Agrícolas.

\author{
PIRACICABA \\ Estado de São Paulo - Brasil \\ Outubro - 2000
}


Dados Internacionais de Catalogação na Publicação (CIP)

DIVISÃO DE BIBLIOTECA E DOCUMENTAÇÃO - Campus "Luiz de Queiroz"/USP

\author{
Bonnin Acosta, Juan José \\ Avaliação de diferentes protétipos de semeadoras em cova para \\ semeadura direta de milho / Juan José Bonnin Acosta. - - Piracicaba, 2000. \\ 84 p. : il. \\ Dissertação (mestrado) - Escola Superior de Agricultura Luiz de Queiroz, \\ 2000. \\ Bibliografia. \\ 1. Dosagem 2. Máquina agrícola 3. Milho 4. Semeadora em cova 5. \\ Semeadkra direta 6: Semente I. Título
}

CDD 633.15

"Permitida a cópia total ou parcial deste documento, desde que citada a fonte -0 autor" 
Autor. Juan Jose Bonnin Acosta

Titulo. Avaliação de protótipos de semeadoras em cova para semeadura direta de milho.

p. item linha

$\checkmark 6$ segunda

$5 \quad 2.2$ primeira

72.2 sétima

92.2 décima primeira

122.3 décima oitava

152.3 décima segunda

57 4.2.1. figura 18

$60 \quad 4.2 .1$ terceira

(3) 4.2 .2 figura 19

694.2 .3 figura 20

766 sétima

776 Décima primeira onde se lê

Referência Bibliográfica

Coelho (1996)

(Molin, 1998a)

(Molin, 1991)

Molin (1996)

Molin (1998b)

Niveis de compactação do solo da área.....

4.2.1 Área experimental de Campos Novos Paulista

Niveis de compactação do solo da área.... Niveis de compactação do solo da área.... Depois da citação de ADEKOYA, L.O., BUCHELE, W.F. A precision punch planter for use in tilled and untilled soils. Jornal of Agricultura Engineering Reserch, Wageningen, v.37, p 171178. 1987.

Coelho, J.L.D. Avaliação de elementos sulcadores para semeadoras em sistemas conservacionistas de manejo de solo. Campinas, 1999. 86 p. Dissertação (M.S.) - Faculdade de Engenheira Agrícola, Universidade Estadual de Campinas. leia-se

Referência Bibliográfica 76

Coelho (1998)

(Molin et al., 1998a)

(Molin e Chang, 1991)

Molin et al., (1998 ${ }^{\mathrm{a}}$ )

Molin et al., (1998b)

Valores do índice de cone para a área...

4.2.2 Área experimental de Campos Novos Paulista

Valores do índice de cone para a área... Valores do índice de cone para a área.... AMEMIYA, M. Conservation tillage in the western corn belt. Jornal of soil. Keny, 32 (6): $29-36,1977$.

ALMEIDA, F.S. Control de ervas. In: IAPAR. Plantio direto no estado do Paraná. Londrina. 1981. 244p.

Coelho, J.L.D. Avaliação de elementos sulcadores para semeadoras em sistemas conservacionistas de manejo de solo.

Campinas, 1998. 86 p. Dissertação (M.S.) -

Faculdade de Engenheira Agrícola,

Universidade Estadual de Campinas. 


\section{DEDICO}

A minha filinha Karin Vivianne,
pela alegria de vê-la cada dia.

À minha esposa Gloria, pelo amor, compreensão, e por que jamais deixo de me incentivar a acreditar que sempre podemos ultrapassar o que achavámos era a fronteira dos nossos limites. 


\section{AGRADECIMENTOS}

A Deus pela vida, pela saúde, pela minha família, pelos verdadeiros amigos e por todas as coisas que sempre me concedeu.

Ao Prof. Dr. José Paulo Molin, pela amizade e orientação na realização deste trabalho e também pela sua infinita capacidade de compreensão.

À Escola Superior de Agricultura "Luiz de Queiroz", Universidade de São Paulo, pela honrosa oportunidade, agradeço.

Aos Professores responsáveis pelas sugestões e orientação na execução desta Dissertação.

À "University of Nebraska-Lincoln" e MARCHESAN Implementos e Máquinas Agrícolas "TATÚ" S.A., pela cedência dos protótipos utilizados no trabalho.

À CAPES, Coordenação e Aperfeiçoamento de Pessoal de Nível Superior, pela concessão de um ano de bolsa de estudos.

A todos os professores e funcionários do Departamento de Engenharia Rural, pelos ensinamentos e cordialidade.

A meu grande amigo Edmilson R. Silva Ruiz, pela sua amizade incondicional, e por todos e cada um dos momentos que passamos nesta etapa.

Ao colega Ricardo Nicolás Zárate, por todo seu apoio, particularmente, como amigo por ter me incentivado sempre na realização deste Mestrado.

Ao amigo Remi Dambrós, pela amizade e companheirismo, agradeço.

A Valéria Modolo e Adriana Pires, por estar sempre quando a gente precisou de amigos de verdade. Agradeço. 
À Republica Paraguaia, principalmente, aos amigos Juan Delgado e Luis Enrique Robledo, pela cordialidade. Agradeço.

A todos os colegas do Curso de Máquinas Agrícolas

A todos as pessoas que direta ou indiretamente contribuíram para a realização deste trabalho, agradeço. 


\section{SUMÁRIO}

Página

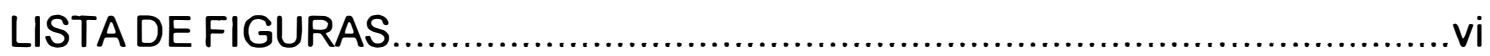

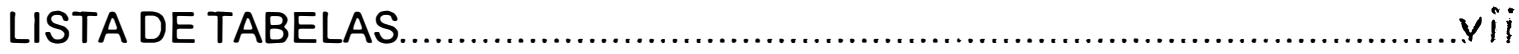

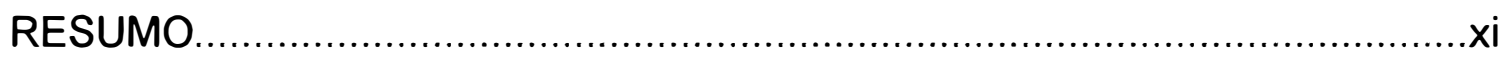

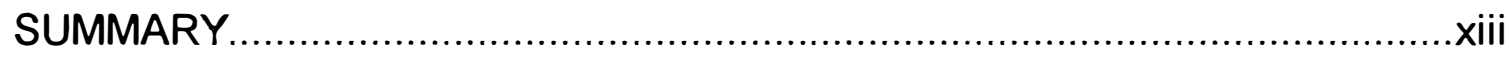

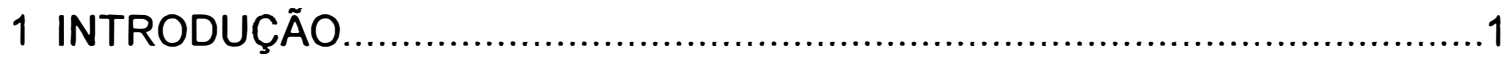

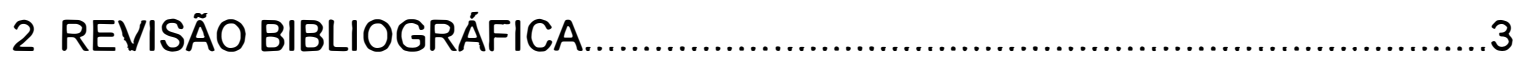

2.1 Considerações sobre o Plantio Direto ..................................................3

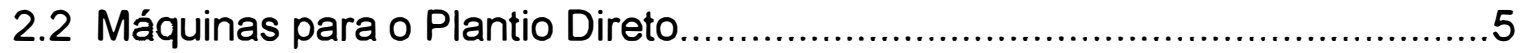

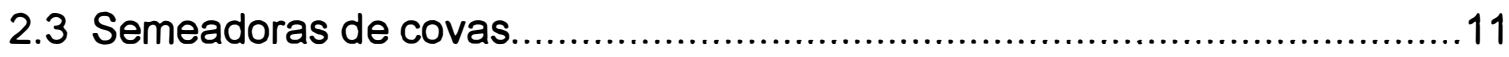

2.4 Parâmetros para medir a eficiência da semeadura...................................16

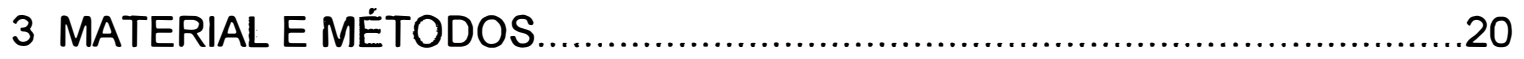

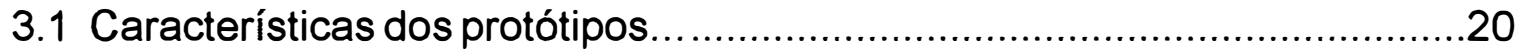

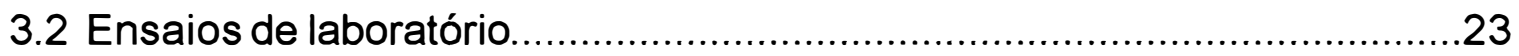

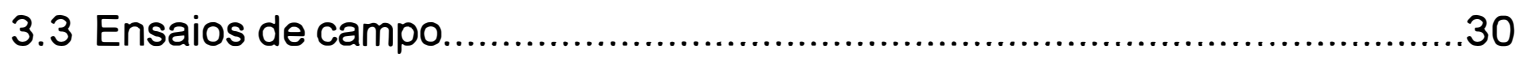

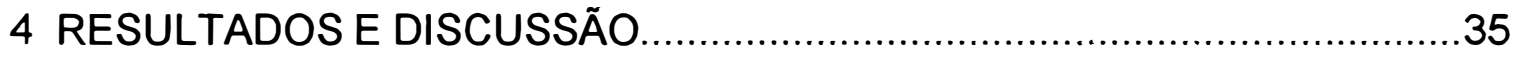

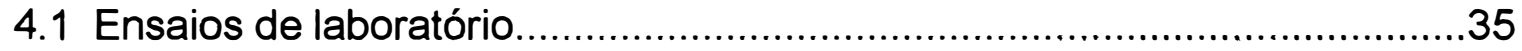

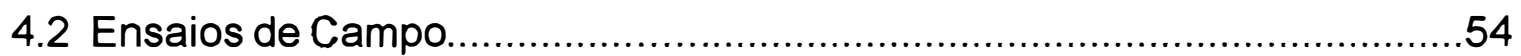

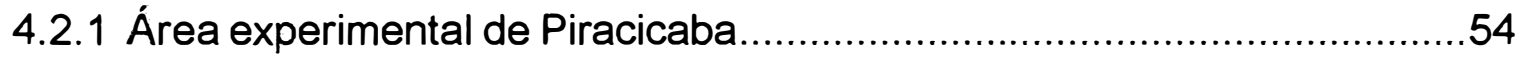

4.2.2 Área experimental de Campos Novos Paulista...................................60

4.2.3 Área experimental de Pirassununga...................................................66

4.3 Considerações praticas para futuros projetos visando a sua utilização comercial. 


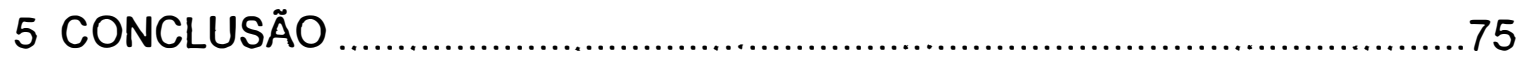

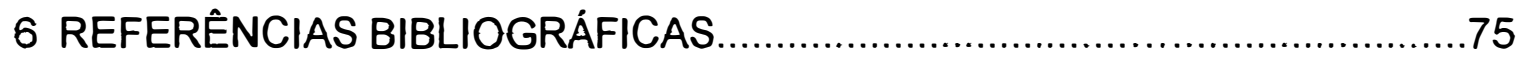




\section{LISTA DE FIGURAS}

Página

1 Mq1 (Molin et al., 1998b) ........................................................21

2 Mq2 (Shaw \& Kromer, 1987) ................................................22

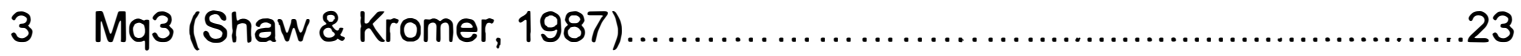

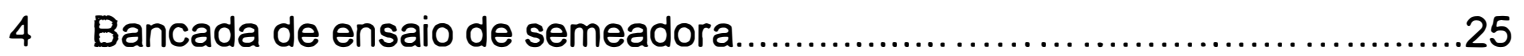

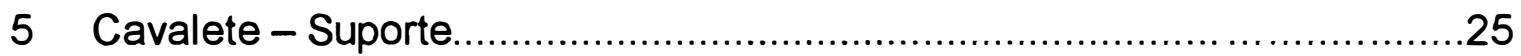

6 Esquema do ajuste do mecanismo dosador da Mq1 .........................26

7 Esquema do ajuste do mecanismo dosador da Mq2 ...........................26

8 Esquema do ajuste do mecanismo dosador da Mq3..........................27

9 Ensaio preliminar da Mq1 na velocidade de 1,5 $\mathrm{m} \mathrm{s}^{-1}$..........................37

10 Ensaio preliminar da Mq1 na velocidade de 2,0 $\mathrm{m} \mathrm{s}^{-1} \ldots \ldots \ldots \ldots \ldots \ldots \ldots . . . . . . . . . . . .38$

11 Ensaio preliminar da Mq1 na velocidade de $2,5 \mathrm{~m} \mathrm{~s}^{-1} \ldots \ldots \ldots \ldots \ldots \ldots \ldots . . . . . . . . . . . .39$

12 Ensaio preliminar da Mq2 na velocidade de $1,5 \mathrm{~m} \mathrm{~s}^{-1} \ldots \ldots \ldots \ldots \ldots \ldots \ldots . . . \ldots 41$

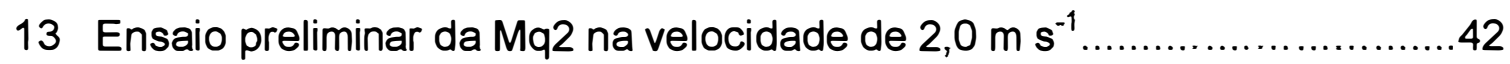

14 Ensaio preliminar da Mq2 na velocidade de $2,5 \mathrm{~m} \mathrm{~s}^{-1} \ldots \ldots \ldots \ldots \ldots \ldots \ldots . . \ldots 3$

15 Ensaio preliminar da $\mathrm{Mq} 3 \mathrm{na}$ velocidade de $1,5 \mathrm{~m} \mathrm{~s}^{-1} \ldots \ldots \ldots \ldots \ldots \ldots \ldots . . . \ldots 45$

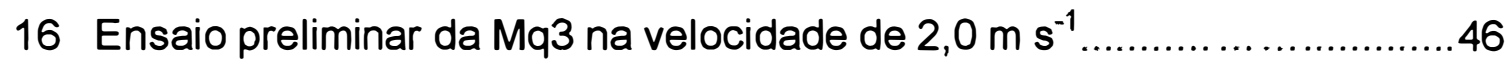

17 Ensaio preliminar da $\mathrm{Mq} 3$ na velocidade de $2,5 \mathrm{~m} \mathrm{~s}^{-1} \ldots \ldots \ldots \ldots \ldots \ldots \ldots .47$

18 Índices de cone da área de Piracicaba.................................................57

19 Índices de cone da área de Campos Novos Paulista............................63

20 Índices de cone da área de Pirassununga.........................................69 


\section{LISTA DE TABELAS}

Página

1 Resultado dos ensaios da regularidade de distribuição longitudinal de sementes en bancada de laboratório para a Mq1 36

2 Resultado dos ensaios da regularidade de distribuição longitudinal de sementes en bancada de laboratório para a Mq2.

3 Resultado dos ensaios da regularidade de distribuição longitudinal de sementes en bancada de laboratório para a Mq3.

4 Resultado dos ensaios da regularidade de distribuição longitudinal de sementes en laboratório para as três máuinas ensaiadas.

5 Resultado das médias dos tratamentos, referente às porcentagens de germinação e danos fisicos provocados às sementes pela Mq1.

6 Resultado das médias dos tratamentos, referente às porcentagens de germinação e danos fisicos provocados às sementes pela Mq1.

7 Resultado do índice de cobertura e matéria seca sobre o solo prévio à semeadura na área experimental de Piracicaba, SP.

8 Resultados médios e coeficiente de variação da densidade do solo e da umidade nas duas profundidades analisadas, no período que antecedeu à semeadura, para a área de Piracicaba, SP

9 Resultados do ensaio da regularidade de distribuição longitudinal de plantas da área experimental de Piracicaba, SP. 
10 Resultado do índice de cobertura e matéria seca sobre o solo prévio à semeadura na área experimental de Campos Novos Paulista, SP

11 Resultados médios da densidade do solo e da umidade nas diferentes profundidades analisadas, no período que antecedeu à semeadura, na área experimental de Campos Novos Paulista, SP.

12 Resultados dos ensaios da regularidade de distribuição longitudinal de plantas da área experimental de Campos Novos Paulista.

13 Resultado do índice de cobertura e Matéria seca sobre o solo prévio à semeadura na área experimental de Pirassununga, SP

14 Resultados médios da densidade do solo e da umidade nas diferentes profundidades analisadas, no período que antecedeu à semeadura, na área experimental de Pirassununga, SP 68

15 Resultados dos ensaios da regularidade de distribuição longitudinal de plantas da área experimental de Pirassununga 


\section{AVALIAÇÃO DE PROTÓTIPOS DE SEMEADORAS EM COVA PARA SEMEADURA DIRETA DE MILHO}

Autor: Juan José Bonnin Acosta Orientador: Prof. Dr. José Paulo Molin

\section{RESUMO}

Recentemente pesquisadores vêm propondo o uso de semeadoras de covas para inserção de sementes no solo. Trabalhos nessa área têm demostrado a viabilidade de seu uso em sistemas de semeadura direta por dispensarem o corte da palha e depositarem as sementes em espaços regulares.

Com base nessas considerações o presente trabalho tem como objetivo avaliar o desempenho de três de semeadoras de covas para semeadura direta de milho, com diferentes configurações e mecanismos dosadores. Os protótipos foram avaliados sob três velocidades, simuladas em condições controladas de bancada e em condições reais de semeadura direta no campo.

As três semeadoras foram obtidas de trabalhos anteriores. A Mq1 proposta por Molin et al. (1998b), consta de uma roda composta por 15 ponteiras radialmente distribuídas em torno de um anel metálico equipada com mecanismo dosador pneumáticos. As pontas, sem movimento relativo, são os elementos ativos que, ao girar a roda, penetram no solo alojando uma semente 
em cada cova. As covas são moldadas pela ação de um ângulo vertical $22^{\circ} \mathrm{e}$ um ângulo longitudinal de $7^{\circ}$.

As outras foram produzidas pelo "Instituf of Landtechnik, University of Bonn", em Bonn, Alemanha, com base no trabalho de Shaw \& Kromer (1987). As duas contam com 15 ponteiras parafusadas em torno de um anel metálico, diferenciando-se só no dosador. A Mq2 é equipada com dosador de dedos prensores e a Mq3 com um mecanismo tipo colher. As covas são moldadas pela ação de um ângulo vertical de $21^{\circ}$ e um ângulo longitudinal de $8^{\circ}$.

Todas foram submetidas a ensaios de bancada com a finalidade de definir o ponto ótimo de sincronização entre o mecanismo dosador e as ponteiras. As velocidades foram de 1,5; 2,0 e 2,5 $\mathrm{m} \mathrm{s}^{-1}$. Posteriormente, foram realizados ensaios de campo em três diferentes áreas experimentais. Os parâmetros para avaliar o desempenho das máquinas, foram os índices de normais, múltiplos e falhos, C.V. e precisão, baseados na Norma ISO 7256-1 (1984). O delineamento adotado foi inteiramente casualisado, em esquema fatorial $3 \times 3$, sendo 3 máquinas e 3 velocidade, com 4 repetições.

Tanto em condições de laboratório como de campo, independente das áreas, a Mq1 obteve o melhor desempenho, quanto à uniformidade de distribuição de sementes. Seus melhores resultados foram obtidos na velocidade de $2,0 \mathrm{~m} \mathrm{~s}^{-1}$.

Para as Mq2 e Mq3, apesar de apresentarem configurações semelhantes, a diferença no mecanismo dosador foi decisiva no desempenho tanto em nível de laboratório como de campo. A Mq2 apresentou o melhor desempenho em laboratório, na velocidade de $2,5 \mathrm{~m} \mathrm{~s}^{-1}$. Esse resultado não foi observado nos ensaios de campo, onde o melhor desempenho foi registrado na velocidade de $2,0 \mathrm{~m} \mathrm{~s}^{-1}$.

$\mathrm{Na} \mathrm{Mq3,} \mathrm{o} \mathrm{melhor} \mathrm{desempenho} \mathrm{foi} \mathrm{observado} \mathrm{na} \mathrm{velocidade} \mathrm{de} \mathrm{1,5} \mathrm{m} \mathrm{s}^{-}$ 1 , tanto nos ensaios de laboratório como de campo. De forma geral, o aumento da velocidade influenciou negativamente no desempenho da máquina para todas as variáveis referentes à uniformidade de distribuição. 


\title{
EVALUATION OF DIFFERENT PUNCH PLANTER NO-TILL PROTOTYPES.
}

\author{
Author: Juan José Bonnin Acosta
}

Adviser: Prof. Dr. José Paulo Molin

\section{SUMMARY}

Recently researchers have proposed the use of punch planters in order to solve punctual problems in agriculture. Some works have demonstrated its applicability, in no-till systems. Because it eliminates counter disks and produce overly spaced plants.

The objective of the present work is to evaluate the performance of three punch planters for no-till corn with different configurations and seed metering. The prototypes were evaluated at three different speeds simulated on a test bench under controlled conditions and under actual no-till conditions in the field.

The three punch planters, called Mq1, Mq2 and Mq3 respectively, were obtained from previous works. Mq1 was proposed by Molin et al. (1998b) which has a wheel composed by 15 punches radially distributed around a metallic ring and a vacuum seed metering mechanism. The punches with no relative movement, are the active elements that penetrates the soil placing a seed in 
each punch wheel the wheel turns around. The holes are formed by the action of a $22^{\circ}$ vertical and a $7^{\circ}$ longitudinal angle of the wheel.

The other two planters were produced by the Instituf of Landtechnik, University of Bonn, in Bonn, Germany based on the work done by Shaw \& Kromer (1987). They are both composed by 15 punches displaced around a metal ring. The difference consist in the seed metering system. Mq2 is equipped with finger pick-up seed meter and Mq3 uses a "spoon" seed meter. The holes are formed by the action of a $21^{\circ}$ vertical and an $8^{\circ}$ longitudinal angle.

Mq1, Mq2 and Mq3 were all tested on a conveyor belt bench in order to define the optimal sincronization point between the seed meter system and the punch. The tested speed were of 1,$5 ; 2,0$ and $2,5 \mathrm{~m} \mathrm{~s}^{-1}$. After that tests were carried out under field conditions in three different experimental areas. The parameters used to evaluate the machines performance were the singles, multiples and misses index, C.V. and precision, all base on the ISO 7256-1 standard (1984). The experimental design was completely randomised, in a $3 \times 3$ factorial structure, being 3 machines at 3 different speed and with 4 repetitions.

The best result was obtained by Mq1 at the speed of $2,0 \mathrm{~m} \mathrm{~s}^{-1}$ under laboratory as well as field conditions, independently of the areas and the uniformity of the seed distribution.

Despite their similar configuration Mq2 and Mq3, the difference in the seed metering mechanism was decisive on their performance under field and laboratory conditions. Mq2 presented the best performance in laboratory trials at the speed of $2,5 \mathrm{~m} \mathrm{~s}^{-1}$ and under field conditions at the speed of $2,0 \mathrm{~m} \mathrm{~s}^{-1}$. In Mq3 the best performance was observed at the speed of $1,5 \mathrm{~m} \mathrm{~s}^{-1}$, under field and laboratory conditions. Speed increase had an overall negative influence on the planters performance for all the variables related to seed uniformity distribution. 


\section{INTRODUÇÃO}

Os métodos convencionais de preparo do solo caracterizam-se pelo seu excessivo movimento, com a finalidade de proporcionar condições adequadas à cultura a ser estabelecida. Isto deu origem a um desequilíbrio ambiental, promovendo uma progressiva degradação da capacidade produtiva do solo, pela excessiva erosão.

A erosão e conservação são desafios que acompanham o homem desde o início da agricultura. Com a evolução da mecanização e do cultivo em áreas extensivas a magnitude da destruição da natureza e da contaminação da água evoluiu proporcionalmente.

Para inverter esse quadro, sistemas conservacionistas de manejo, como o sistema de preparo reduzido e de semeadura direta, foram desenvolvidos com 0 objetivo de reduzir a mobilização do terreno, consequentemente diminuindo o número de operações. Portanto, também reduzem a demanda energética, com a correspondente minimização dos custos operacionais. Além disso, mantém uma cobertura morta na superfície.

Assim a produção de grãos, fundamentada em sistemas sustentáveis, revela a necessidade de diversificar o sistema produtivo na busca de competitividade dentro do negócio agrícola. Isso exige da pesquisa e das indústrias de máquinas agrícolas, o desenvolvimento de equipamentos e de mecanismos cada vez mais versáteis e precisos. 
Desses equipamentos, as semeadoras são as máquinas mais importantes, visto que as condições do solo e da cobertura geralmente não são tão favoráveis à correta distribuição de sementes por unidade de área, quanto às verificadas nos preparos com alta mobilização.

Os fabricantes de semeadoras tem produzido, nos últimos anos, máquinas de melhor qualidade, atendendo as exigências agronômicas das culturas e a crescente adoção do sistema de plantio direto. As mudanças estão ocorrendo, principalmente nos sistemas de rompimento do solo, distribuição e posicionamento das sementes no sulco. Mas algumas limitações ainda persistem. Muitas idéias e conceitos novos têm sido propostas para melhorar o desempenho das semeadoras na palhada.

Recentemente pesquisadores vêm propondo o uso de semeadoras de covas para inserção de sementes para resolver problemas específicos da agricultura. Trabalhos nessa área têm demostrado a viabilidade de seu uso em sistemas com semeadura direta, pois movimentam uma quantidade mínima de solo e de palha, rolando sobre a mesma sem precisar cortá-la. A precisão na colocação das sementes nas covas é outro fator relevante deste conceito de máquinas, especialmente para as culturas que têm sua produtividade afetada pela precisão no espaço entre plantas, como o caso do milho, girassol, algodão e o feijão.

Com base nessas considerações e com a finalidade de poder proporcionar maiores informações para futuros projetos visando a sua utilização comercial, o presente trabalho tem como objetivo principal avaliar o desempenho de três protótipos de semeadoras rotativas de covas para semeadura direta de milho, com diferentes configurações e mecanismos dosadores. Os protótipos foram avaliados sob três velocidades de deslocamento, simuladas em condições controladas de bancada e em condições reais de semeadura direta no campo. 


\section{REVISÃO BIBLIOGRÁFICA}

\subsection{Considerações sobre o Plantio Direto}

A prática da agricultura de um modo geral, tem sido uma atividade predatória em termos de conservação do solo. As terras agrícolas vêm sofrendo um processo acelerado de degradação de sua capacidade produtiva, tanto pelo inadequado e mau uso, devido à mecanização intensa e desordenada, como pelos sistemas agrícolas baseados na monocultura ou sucessões continuas de culturas (Mondardo, 1984).

Freqüentemente, a perda de solo é aceitada como um fenômeno natural inevitável. No entanto indica desequilíbrio do ecossistema em razão do emprego de métodos inadequados de cultivos (Derpsch et al., 1991). A mobilização da camada arável, proporcionada pelos sucessivos preparos, modifica sua estrutura, alterando a grandeza e a relação de seus parâmetros físicos (Kluthcouski, 1998).

Gassen \& Gassen (1996) comentam que tem ocorrido mudança significativa na visão da sociedade sobre a necessidade de se manter e recuperar os recursos naturais e surgem questionamentos sobre a perda de solo por erosão e poluição da água.

De acordo com Adegas (1997), a sustentabilidade rural moderna está baseada nos parâmetros do economicamente viável e ecologicamente correto. Para tanto, as técnicas de manejo e conservação de solo e da água devem 
merecer atenção especial, pois a substituição do ecossistema natural pelo agrícola pode provocar alterações nas propriedades físicas, químicas e biológicas (Lopes de Oliveira, 1997).

Devido a estas características, sistemas de produção fundamentados no mínimo revolvimeto e na manutenção de níveis adequados de matéria orgânica assumem caráter relevante (Fancelli \& Favarin, 1989). Assim, hoje visa-se sistemas e práticas para a conservação do solo, como o uso do preparo reduzido com o escarificador e da semeadura direta (Furlani et al., 1999).

A ASAE (American Society of Agricultural Engineering, 1997) e Coelho (1997), definem como preparo conservacionista, o sistema que mantém um mínimo de $30 \%$ de cobertura vegetal na superfície do solo depois da semeadura, ou um mínimo de $1 \mathrm{t} \mathrm{ha}^{-1}$ de matéria seca durante o período crítico de erosão. Para Amemiya (1977), um sistema conservacionista pode ser entendido como qualquer sistema que reduz perdas de solo ou água.

A cobertura do solo com resíduos vegetais ou palha é, sem duvida, uma alternativa efetiva no controle da erosão e no aumento da produtividade (Lombardi, 1991). Portanto, a espessura e a facilidade de decomposição da cobertura morta são de extrema importância num sistema conservacionista. (Schultz, 1987).

A cobertura morta, proporcionada pelos restos culturais de culturas anteriores, também serve como elemento isolante, capaz de protegê-lo das drásticas variações de temperatura, ocorridas durante o dia. Mantém o solo úmido, reduz consideravelmente as perdas por evaporação, resultando em maior armazenamento e oferta de água, enriquecendo-o em matéria orgânica e possibilitando um ambiente favorável ao desenvolvimento de invertebrados, inclusive de inimigos naturais das pragas e doenças (Almeida, 1981).

Para Bertoni \& Lombardi (1990) a cobertura vegetal inerente ao sistema de plantio direto, tende a melhorar a estrutura da camada superficial do solo, auxiliando no controle da erosão, ao proteger a superfície contra o 
impacto das gotas da chuva, impedindo sua desagregação e a formação de camadas compactadas que não deixam a água infiltrar e dificultando o escoamento acelerado da enxurrada.

Além dos benefícios na conservação, a palha exerce uma diminuição da emergência das plantas daninhas que é atribuída ao impedimento físico da camada vegetal, como também a possíveis efeitos alelopáticos exercidos pela cobertura vegetal em descomposição (Vieri Filho, 1986).

De acordo com Derpsch et al. (1991), vários outros fatores que também influem no processo de erosão, têm sido freqüentemente supervalorizados quanto aos seus efeitos no controle da erosão ou enfocados de maneira não objetiva em relação ao efeito especial da cobertura do solo, citando-se entre eles o teor de húmus, disponibilidade de cálcio, estabilidade dos agregados e outros.

O plantio direto tem demostrado ser um sistema de produção que atende esses requisitos. O plantio na palha vem se tornado uma verdadeira filosofia de vida, que tem no desenvolvimento de uma agricultura sustentável seu mais importante objetivo. Aliar produtividade à técnicas que permitam a exploração racional do solo é apenas um dos aspectos do sistema, que depende principalmente da reestruturação da maneira de pensar do agricultor, na medida em que isso representa a manutenção da capacidade produtiva da terra (Pimentel, 1988).

\subsection{Máquinas para Plantio Direto}

Segundo Coelho (1996) a renovação no uso e manejo do solo, fez com que as semeadoras passassem a assumir importância fundamental nos modernos sistemas de produção agricola. 
O plantio direto dispensa operações preliminares e inclui a existência de cobertura vegetal sobre a superfície que necessita ser cortada para a colocação da semente em contato com o solo (Sattler, 1996). Isso requer da semeadora algumas características próprias, referente ao corte eficiente da palhada ou restos culturais, à abertura do sulco e à colocação da semente e do fertilizante em profundidade correta e em contato com o solo. Também é primordial que as máquinas apresentem adequada precisão na regularidade de distribuição de semente (Embrapa, 1994). Para Landers (1995) o plantio direto precisa de semeadoras versáteis e resistentes que sirvam para culturas e solos distintos.

O primeiro equipamento para semeadura direta que surgiu no mercado baseava-se no princípio de enxadas rotativas. A pouca largura útil devido ao eixo rígido e ao engate no hidráulico de três pontos do trator, aliada à baixa velocidade de trabalho e freqüentes reparos, diminuíram sensivelmente a demanda por essa máquina, resultando na suspensão de sua fabricação, principalmente depois que semeadoras mais eficientes se tornaram disponíveis no mercado (Derpsch et al., 1991).

Mais tarde foram desenvolvidos sistemas de disco de corte, que têm por função cortar através dos restos culturais e abrir o sulco para a penetração dos conjuntos que irão depositar a semente e o adubo. De acordo com Schultz (1987) as máquinas hoje em uso para semeadura direta são basicamente, de dois tipos diferentes. O mais comum consiste em um sulcador que rompe uma camada estreita de solo e ao mesmo tempo deposita o fertilizante um pouco abaixo da semente. Vem a seguir um dispositivo que dentro da fenda, deposita a semente na profundidade requerida. Duas rodas de cobertura e manutenção de profundidade de trabalho da semeadora, fecham a abertura, compactando levemente a terra em volta da semente.

Esse sistema recebeu várias derivações, como por exemplo a utilização do sulcador de disco duplo defasado de dois discos com diâmetros diferentes, 
na tentativa de fazer com que o disco maior corte a palha e o menor promova a abertura do sulco, dispensando o disco de corte (Coelho, 1998).

Entretanto, pela variabilidade dos tipos de solos, é difícil que uma semeadora atenda a todas as condições, principalmente porque a maioria dos equipamentos utilizados no sistema é constituído por modelos adaptados pelo fabricantes por meio de "kits" ou possui adequações feitas pelo próprio agricultor (Molin, 1998a)

Morrison (1978) relatou que um dos principais problemas do plantio direto no estado de Kentucky, USA, refere-se à menor emergência e à desuniformidade das plantas, proporcionadas pelas semeadoras para plantio direto em comparação com as semeadoras para sistema convencional. 0 mesmo autor avaliou a performance de semeadoras de milho quanto à emergência das plantas e observou grande variabilidade no stand obtido pelas semeadores comerciais.

Cobra (1986) afirma que apesar das vantagens proporcionadas pelo plantio direto, ele exige máquinas pesadas e especializadas. Nesse ponto o sistema apresentava algumas limitações pois os equipamentos para tal fim ainda deviam alcançar mais elevados níveis de eficiência.

De acordo Portella et al. (1993) os maiores problemas encontrados durante as operações com semeadura direta, são resultantes de uma distribuição irregular dos resíduos durante a colheita da cultura anterior. Em solos leves a palha é puxada para dentro do sulco, sem ser cortada. A semente é colocada sobre a palha e o solo é então depositado ao redor desta mistura de palha e semente, não havendo um perfeito contato, o que é certamente importante, especialmente quando a semeadura é feita em condição de baixa umidade. Quando a semeadura é feita sobre uma superfície com alta densidade de resteva, a penetração dos discos é reduzida e a semente é colocada na superfície ou entre a camada de resíduos, mas não em contato com o solo, resultando em má germinação. Quando grandes quantidades de 
resíduos são formadas em frente aos discos, estes ao invés de cortar passam por cima. Este fenômeno ocorre mais freqüentemente em superfícies fofas ou em lavouras com umidade.

Segundo Balastreire (1987) vários fatores afetam a operação de semeadura, podendo estes estarem relacionados à semente, ao solo e à máquina. Com relação à semente, merecem destaque a quantidade, a uniformidade de distribuição e a cobertura da semente. A maioria das máquinas são acionadas pelo rodado. A eficiência do funcionamento desse dispositivo de tração tem relação direta com as condições de contato entre o rodado e o solo, influenciado pela carga vertical, dimensões e pressão de insuflagem e pela propriedades físicas do solo. O tipo de sulcador é fator determinante na profundidade e uniformidade de distribuição das sementes.

Wilkins et al. (1983) testaram quatro diferentes tipos de sulcadores para semente, disco simples, discos duplo, facão e enxada, e concluíram que o tipo de sulcador influiu significativamente na densidade das paredes e na retenção de umidade do sulco, como na profundidade e na distribuição longitudinal das sementes, afetando dessa forma a eficiência de emergência das plantas.

Morrison \& Gerik (1985) testaram quatro mecanismos para controle de profundidade de plantio e concluíram que as variações na superfície ocasionadas pela presença de palha podem afetar o estande final, devido às interações dos mesmos com o mecanismo de controle de profundidade.

Sattler et al. (1998) estudaram três índices experimentais como parâmetros comparativos de mobilização de solo na linha, em semeadura direta. Os parâmetros de comparação na avaliação do desempenho de semeadoras foram os índices de mobilização, elevação e movimentação relativa. Os resultados indicam que o índice de movimentação relativa poderá ser um parâmetro qualitativo de comparação, entre semeadoras ou sulcadores 
em semeadura direta, quando as profundidades de trabalho dos equipamentos forem diferentes.

Trabalho semelhante a este foi feito por Coelho (1998) onde avaliou a capacidade operacional de cinco configurações de elementos sulcadores, por meio do cálculo do volume de solo mobilizado por unidade de área e também a exigência de tração em cada condição.

É amplo o trabalho de pesquisa visando definir os efeitos da densidade populacional e da uniformidade de espaçamento entre sementes na linha de semeadura, sobre a produção para as diversas culturas. No entanto, normalmente é vinculado a objetivos específicos como a definição de espaçamento para uma dada região e cultivar (Molin, 1991).

Um importante fator na otimização do crescimento e desenvolvimento das plantas é a localização apropriada das sementes no solo durante a operação de semeadura. Chhinnan et al. (1975) analisaram a desuniformidade na distribuição longitudinal de sementes e apontaram dois tipos de erros. $O$ primeiro resulta da disposição de múltiplas sementes ou falhas quando o desejado é uma única semente em cada posição, denominado de erro de dosagem devido ao mecanismo dosador. O segundo tipo é resultado de desvios na colocação das sementes com relação à posição desejada, sendo denominado de erro de deposição.

De acordo com Embrapa (1997), um dos parâmetros de grande influência na precisão de distribuição de sementes no solo é a velocidade de deslocamento da máquina. Moreira et al. (1978) afirmaram que a velocidade de trabalho entre os parâmetros estudados foi o que mais influenciou $o$ desempenho da semeadora.

Portella et al. (1998) estudou o efeito da velocidade de trabalho das semeadoras sobre o desempenho de mecanismos dosadores, na semeadura de milho; nessa pesquisa utilizaram 12 semeadoras, estudando quatro níveis de velocidades de deslocamento. Os autores concluíram que o melhor 
desempenho foi observado para semeadoras equipadas com mecanismo dosador alveolado horizontal e baixa velocidade de deslocamento.

Segundo Pasqua (1996) a desuniformidade na distribuição de sementes, compromete o desempenho da cultura, alterando os componentes de rendimento e proporcionando queda na produtividade de grãos, uma vez que não ocorre aproveitamento total da área e dos insumos disponíveis.

Kurachi et al. (1989) mostraram que a uniformidade em distribuição longitudinal de sementes é uma das caracteristicas que mais contribui para a obtenção de um stand adequado de plantas e consequentemente de boa produtividade.

Delafosse (1986) relata que, a distribuição longitudinal de sementes no sulco de semeadura exerce influência direta sobre o rendimento da cultura semeada. Estudos realizados mostram que a falta de uniformidade entre plantas, pode resultar em perdas de $15 \%$ ou mais na cultura do milho, $35 \%$ na cultura de girassol e 10 \% na cultura de soja. Portanto, torna-se necessário o desenvolvimento de novas máquinas mais eficientes e evoluídas tecnologicamente.

Segundo Mantovani e Bertaux (1990), os fabricantes de semeadoras, com a finalidade de proteger o mecanismo dosador distribuidor contra resíduos deixados nos solos, têm optado pela colocação do mecanismo o mais distante possivel da superficie do terreno. Isto implica em tubos de descarga mais compridos, proporcionando às sementes um caminho mais longo para percorrer, aumentando a possibilidade de rebotes que contribuem para irregularidade na distribuição longitudinal.

Embora muitos esforços tenham sido feitos, não existe um consenso entre pesquisadores e agricultores, de qual a melhor maneira de suplantar a dificuldade imposta pela presença de palha na abertura e fechamento do sulco por ocasião da semeadura (Portella et al., 1993). Consequentemente, para o desenvolvimento da máquina para plantio direto, tornou-se importante 
determinar as limitações dos equipamentos e formular alternativas para auxiliar o setor industrial

\subsection{Semeadoras de covas}

A tentativa de utilização de cova para a deposição de sementes sem o removimento do solo já vem sendo perseguida a mais de três décadas. As semeadoras manuais conhecida como matracas ou saraquás foram as primeiras a adotar o conceito de semeadura em cova. Estes tipos de semeadoras ainda são bastante utilizadas em áreas mais acidentadas e com pedras ou tocos, onde não é possivel a mecanização. Almeida (1993) avaliou o desempenho de uma matraca, com a ponta adaptada. Segundo o autor, a colocação de uma chapa metálica pontiaguda resultou em melhor penetração no solo, cortando e afastando a palha, ao invés de dobrá-la e enterrá-la no solo.

Jafari \& Fornstrom (1972) desenvolveram uma semeadora de cova para beterraba açucareira. A máquina constitui-se de uma roda metálica onde são distribuídas seis ponteiras cônicas invertidas, responsáveis por abrir as covas no solo, para depositar as sementes. O mecanismo dosador é constituido por um disco vertical com um movimento sincronizado com a roda, dosando e distribuindo uma única semente por cova. Em ensaios a campo, a velocidades de 1,$3 ; 1,8$ e 2,2 $\mathrm{m} \mathrm{s}^{-1}$, a máquina apresentou um bom desempenho na precisão de dosagem e uniformidade de distribuição longitudinal das sementes, com porcentagens de $97,6 \% ; 96,3 \%$ e $94 \%$, respectivamente.

Heinemann et al. (1973) desenvolveram dois modelos de semeadora de precisão usando pinos para a abertura de covas. As máquinas utilizaram o mesmo mecanismo dosador de rotor vertical com carga interna e descarga externa num bico responsável por dirigir as sementes para cada cova. $\mathrm{Na}$ 
primeira semeadora as covas eram formadas por um cilindro pneumático, que durante o retorno movimenta o mecanismo dosador, depositando uma semente por cova. A segunda semeadora usava uma esteira com rodas denteadas. As covas eram feitas por pinos cilíndricos distribuídos em torno da roda dianteira. Esta máquina apresentou problema de deposição das sementes nas covas.

Wilkins et al. (1979) utilizaram também o conceito de pinos distribuídos em torno de uma roda para a abertura de covas, para solucionar problemas de formação de crostas em solos salinos. Foi desenvolvida uma semeadora utilizando pinos cilíndricos magnetizados. As sementes eram cobertas com uma camada de oxido de ferro $\left(\mathrm{F}_{3} \mathrm{O}_{4}\right)$ podendo ser desta forma coletadas pelos pinos. Em ensaios com sementes de alface com velocidades de operação 0,4 $\mathrm{m} \mathrm{s}^{-1}$ e $0,8 \mathrm{~m} \mathrm{~s}^{-1}$, a relação semente/cova atingiu indices de $98,3 \%$ e $88 \%$ respectivamente. Em nenhum dos ensaios foram encontradas sementes duplas. Este método resultou numa maior emergência em menor tempo em comparação com a semeadura convencional.

Outra importante aplicação do uso de covas é associada ao cultivo sobre lençol plástico. Um dos primeiros a pesquisar o uso dessa técnica foi Hunt (1961), citado por Molin (1996), que desenvolveu uma semeadora de covas para hortaliças, montada na parte posterior de uma máquina que estendia plástico sobre os canteiros. A mesma constava de quatro pontas em torno de uma roda que furava o plástico e depositava as sementes em covas. Cada ponta, mecanicamente ativada, abria quando estava dentro do solo.

Outras idéias surgiram como a de Shaw et al. (1978) que desenvolveram uma semeadora de covas com ponteiras em forma de cunha, mecanicamente ativas, montadas na beira de duas rodas. O mecanismo dosador distribuía através de um tubo, uma semente por cova, quando as ponteira entravam dentro do solo. Os autores observaram algumas limitações na abertura das covas, como aderência de solo, entupimento e dificuldade para trabalhar na palha. 
Hezroni et al. (1986) também desenvolveram uma semeadora de cova para trabalhar em cultivos sobre plástico. A máquina possuía uma única ponteira em forma de cunha, que era ativada por um sistema electromecânico ou pneumático. O dosador era ativado por um mecanismo biela-manivela, que distribuía através de uma tubulação uma semente por cova.

Shaw et al. (1986) desenvolveram uma semeadora de cova composta por seis pontas cônicas na sua periferia. O mecanismo dosador estava constituído por uma bomba que injetava um gel facilitador do transporte da semente, em baixa pressão e uma válvula solenóide era a responsável por dosar e depositar as sementes nas covas.

Conceito semelhante foi proposto por Adekoya \& Buchele (1987) para semeadura de milho e outros tipos de sementes similares em covas. O projeto consistia de 12 ponteiras em forma de cunha articulada distribuídas na periferia de uma roda. O dosador era acionado por meio da rotação da roda, por um mecanismo biela-manivela. A deposição das sementes nas covas era feita através de uma tubulação que apresentava as mesmas dimensões internas das ponteiras. Cada ponteira apresentava um sistema de abertura para a deposição da semente na cova e fechava automaticamente por meio da mola, evitando deste modo o entupimento ou aderência do solo à mesma. $O$ ensaio de campo mostrou uma diminuição da ocorrência de uma semente por cova de $91 \%$ a $59 \%$, quando a velocidade aumentava de $0,8 \mathrm{~m} \mathrm{~s}^{-1}$ para 2,2 $\mathrm{m} \mathrm{s}^{1}$.

Wijewardene (1980) projetou uma semeadora manual para injeção rotativa de sementes, constituída de 6 injetores distribuídos na periferia de uma roda. Um mecanismo dosador transferia as sementes para cada injetor no instante em que o solo era perfurado.

Singh et al. (1980) descrevem problemas de aderência de solo e entupimento com resíduo de palha, observados em ensaios de campo de diferentes tipos de semeadoras de covas manuais. Os mesmos problemas foram observados por Choudhury (1985). 
Com o objetivo de possibilitar a automatização das operações de semeadoras manuais, Molin \& D'Agostini (1996) desenvolveram uma semeadora de cova para trabalhar em áreas mais acidentadas e com pedras ou tocos. A mesma constava de 12 ponteiras radialmente dispostas em uma roda e que executava a operação de semeadura ao rolar sobre o terreno. Cada ponteira simulava a operação executada por uma matraca, depositando uma semente em cada cova. A distribuição de semente foi avaliada às velocidades de $0,5 \mathrm{~m} \mathrm{~s}^{-1}$ e $0,7 \mathrm{~m} \mathrm{~s}^{-1}$. As porcentagens de espaçamentos normais variaram entre $64 \%$ e $61 \%$ respetivamente.

Shaw \& Kromer (1987) propuseram a utilização de ponteiras fixas em conjunto com uma combinação de ângulos, visando eliminar os problemas de aderência de solo, entupimento com resíduo de palha e a necessidade de lubrificação constante das semeadoras equipadas com ponteiras mecanicamente ativadas. A máquina era constituida por 12 ponteiras fixas com pequenos furos laterais, distribuídos em torno de uma roda de metal com diâmetro de $720 \mathrm{~mm}$, inclinação vertical de $30^{\circ}$ e ângulo de desalinhamento longitudinal de $10^{\circ}$. Esse arranjo resultava num deslocamento lateral das ponteiras, formando uma elipse dentro do solo e possibilitando a liberação das semente através de um furo no lado oposto ao solo deslocado. O protótipo foi equipado com um mecanismo dosador do tipo colher. Ensaios de laboratório a velocidade de $1,5 \mathrm{~m} \mathrm{~s}^{-1}$ revelaram ocorrência de espaçamentos normais entre sementes de 89,2 \%; múltiplos de 8,1\%; e falhos de 2,7\%.

Debicki \& Shaw (1996), baseados nas experiências obtidas por outros pesquisadores, decidiram dar continuidade aos trabalhos que realizaram Shaw \& Kromer (1987). Neste novo protótipo adotaram um mecanismo dosador a vácuo, sendo aumentado o diâmetro da roda para $1 \mathrm{~m}$, reduzido o angulo vertical para $15^{\circ}$ e aumentado o número de ponteiras para 15 unidades. $A$ máquina foi submetida a vários ensaios de laboratório com a finalidade de 
encontrar o ponto ótimo de sincronização entre o mecanismo dosador e as ponteiras.

Posteriormente, baseando-se no conceito de ponteiras fixas, Molin et al. (1998a) projetaram e desenvolveram uma semeadora de cova para semeadura direta de milho. O protótipo contava de uma roda composta por 15 pontas, radialmente distribuídas em torno de um anel metálico, com mecanismo dosador a vácuo. As pontas, sem movimento relativo, eram os elementos ativos que, ao girar da roda, penetravam no solo e alojavam uma semente em cada cova. As covas eram moldadas pela ação de um ângulo vertical de $22^{\circ}$ e um ângulo de $7^{\circ}$ com o eixo longitudinal. $O$ índice de plantas com espaçamentos normais ficou entre $62,9 \%$ e $74,6 \%$ para uma velocidade de $2,0 \mathrm{~m} \mathrm{~s}^{-1}$.

$\mathrm{Na}$ continuidade, Molin (1998b) evoluiu com a construção de um segundo protótipo, com o objetivo de testar a possibilidade de variação da população de milho, fazendo variar o espaçamento entre plantas. O projeto foi baseado no protótipo anterior, para o qual foram construídas três rodas, com diâmetros de 654 mm, $825 \mathrm{~mm}$ e $1000 \mathrm{~mm}$. Cada roda mantinha a mesma quantidade de ponteiras, tendo como única alteração os comprimentos. Desta forma, cada roda podia ser montada na mesma unidade anterior. Como resultado disto foi possível obter um espaçamento entre pontas de $136 \mathrm{~mm}$, $165 \mathrm{~mm}$ e $210 \mathrm{~mm}$. O índice de plantas em espaçamento normal chegou a valores acima de $80 \%$. Além de avaliar os parâmetros de desempenho tanto no laboratório como no campo, quantificaram o volume de solo movimentado em comparação com uma semeadora de plantio direto comercial. O volume de solo mobilizado pela menor roda de pontas foi de $46 \%$ menor que aquele movimentado por uma máquina comercial equipada com abridor de sulcos de disco duplo. Este volume foi linear e inversamente proporcional à distância entre ponteiras.

Buscando uma alternativa para as propriedades que dispõem de pequenas fontes de potência, Luciano et al. (1998) projetaram uma semeadora 
adubadora por cova, acopláveis a tratores de rabiças. Em uma primeira avaliação, o protótipo apresentou algumas limitações quanto à profundidade e o sincronismo na queda de sementes e adubo com a abertura das covas. Segundo os autores, isto deve-se à falta de um mecanismo que permita a variação da dosagem de fertilizantes e de um dosador de semente mais preciso.

\subsection{Parâmetros para medir a eficiência da semeadura}

Com base nas evidências já mencionadas é bem visível a importância dos ensaios de semeadoras, tanto em laboratório como a campo, visando cada vez mais à satisfação dos consumidores, bem como à maior produtividade e lucratividade da agricultura.

Segundo a Norma ISO 7256-1 (International Organization for Standardization, 1984) os parâmetros baseados no espaçamento referência $\left(X_{\text {ref }}\right)$ resultam num bom indicador $d a$ distribuição dos espaçamentos. $O$ índice de espaçamentos normais compreende os espaçamentos entre 0,5 e 1,5 $\mathrm{x}_{\text {ref }}$, o índice de múltiplos representa os espaços menores que 0,5 $x_{\text {ref }}$, e para 0 índice de falhas, considera-se os espaços maiores que 1,5 $x_{\text {ref. }}$ A precisão é definida como a média da variabilidade espacial entre plantas medida pelo coeficiente de variação dos espaços classificados como normais e não é afetado pelo indices de múltiplos ou falhas.

Para culturas que requerem uma distância e profundidade uniforme entre plantas como é o caso de sementes graúdas, algodão, feijão, girassol, milho e soja, a capacidade de distribuição das sementes distanciadas uniformemente na linha, é uma característica desejável nas semeadoras de precisão e um dos principais parâmetros de avaliação do desempenho das máquinas (Kachman \& Smith, 1995). Segundo os autores, a comparação dos 
parâmetros utilizados para caracterizar a distribuição de sementes ou plantas em ensaios de semeadoras de precisão, o espaçamento médio e o desvio padrão não são indicadores precisos para avaliar a eficiência da semeadora. Sugerem o cálculo da precisão entre os espaços considerados aceitáveis, que se situam entre valores de 0,5 $x_{\text {ref }}$ e 1,5 $x_{\text {ref }}$. Quanto menor o valor da precisão, maior quantidade de espaços medidos próximos à distância de semeadura de referência estabelecida para a cultura.

De acordo com Kurachi et al. (1989), as populações de plantas são distribuidas em classes de freqüência, com amplitude de 0,1 $\mathrm{X}_{\text {ref, }}$ sendo que o valor de referência é recomendado agronomicamente, para cada cultura. Segundo os autores, os coeficientes de variação são calculados sobre toda a população de espaçamentos e o valor de $x_{\text {ref }}$ deve ser mantido pela razão de que uma máquina pode estar semeando com um coeficiente de variação próximo ou igual a zero, porém com espaçamento discrepante em relação ao recomendado agronomicamente para uma dada cultura. Para este caso avaliando-se somente sob os aspectos de eficiência da máquina seria perfeito, porém do ponto de vista agronômico seria indesejável. Outra razão é o espaçamento referência ( $X_{\text {ref }}$ teórico). Ele depende das opções oferecidas pelo fabricante quanto às regulagens do mecanismo dosador, variando de uma máquina para outra e tornando impossivel a comparação de populações de espaçamentos distribuídos em intervalos com amplitudes desiguais.

Tourino e Klingsteiner (1983) adotaram critérios para avaliação de semeadoras de precisão, considerando como de desempenho ótimo a semeadora que distribuir entre $90 \%$ e $100 \%$ das sementes na faixa de 0,5 e $1,5 \mathrm{X}_{\text {ref }}$; bom desempenho, entre $75 \%$ e $90 \%$; regular, entre 50 e $75 \%$; e insatisfatório para a semeadora cuja distribuição de sementes na faixa de aceitáveis situar-se abaixo de $50 \%$.

Coelho (1997), baseando-se nos mecanismos dosadores empregados nas semeadoras de precisão no Brasil, os quais dispõem de um nível 
tecnológico bastante heterogêneo, estabeleceu requisitos de regularidade de distribuição longitudinal de sementes e sugeriu critérios de porcentagem mínima de espaçamentos normais e coeficiente de variação máximo, para resultados de ensaios de laboratório. O autor sugere que para os mecanismos dosadores de discos perfurados, dedos prensores e pneumáticos, valores mínimos de $60 \%, 75 \%$ e $90 \%$ de espaçamento normal e coeficiente de variação máximo de $50 \%, 40 \%$ e $30 \%$, respectivamente.

Jasa \& Dickey (1982) propuseram um índice de semeadura para avaliar o desempenho das máquinas. Este índice é um indicador da porcentagem média de falhas obtidas pelo espaçamento para cada semente. Este espaçamento ideal é baseado na uniformidade de espaçamento médio entre plantas em toda a fileira. A porcentagem de falha é obtida pelo cociente entre a diferença da distância atual e o espaçamento ideal, onde o resultado é multiplicado por 100. De acordo aos autores o índice de falha está compreendida entre os valores de 0 e 5 . Um índice máximo de 5 pontos significa um erro menor que $10 \%$. Um índice de 0 é resultado de um erro acima de $50 \%$.

Pasqua et al. (1996) propuseram emprego de técnicas estatísticas de controle de qualidades em operações de semeadura de milho. Para a avaliação do desempenho definiram os indicadores de qualidade da semeadura de milho, como sendo número de sementes por metro no sulco, espaçamento entre sementes e profundidade de colocação das sementes. Para cada indicador foram distribuídos os limites de especificação ou os padrões de qualidade que cada um deveria respeitar, de modo que a qualidade desejada fosse realmente alcançada. Essas especificações foram determinadas baseadas em critérios agronômicos e econômicos. Os resultados são apresentados em forma de histogramas e permitem visualizar a freqüência com que certos eventos ocorrem. Permitem também inferir quanto de variação existe em qualquer processo. 
Ferreira et al. (1998) propuseram um coeficiente tecnológico para avaliação de semeadoras para plantio direto, sem a necessidade de avaliação a campo. A máquina é avaliada através da análise visual, a partir da separação dos mecanismos da semeadora, segurança e manutenção após ser segmentada em 10 itens: o sistema de acoplamento, rodados, mecanismos sulcadores, sistemas referente as sementes, sistemas referentes ao adubo, sistema de recobrimento e compactação dos sulcos, segurança na operação da semeadora, multi-funcionalidade da semeadora, aspectos gerais e acessórios. 


\section{MATERIAL E MÉTODOS}

\subsection{Características dos protótipos}

Para atender aos objetivos propostos neste trabalho foram selecionados três protótipos de semeadoras rotativas de covas, que foram obtidos de trabalhos anteriores, de diferentes procedências. A primeira semeadora, proposta por Molin et al. (1998 b), designáda como Mq1, é apresentada na Figura 1. Apresenta como principal característica uma roda composta por 15 ponteiras de $125 \mathrm{~mm}$ de comprimento, radialmente distribuídas em torno de um anel metálico, com espaçamento fixo entre ponteiras de $136 \mathrm{~mm}$, dando como resultando um diâmetro externo de $650 \mathrm{~mm}$. As pontas, sem movimento relativo, são os elementos ativos que, ao girar a roda, penetram no solo alojando uma semente em cada cova. As covas são moldadas pela ação de um ângulo vertical de $22^{\circ}$ e um ângulo horizontal de $7^{\circ}$ com o eixo longitudinal. O protótipo conta com um mecanismo dosador pneumático da marca John Deere, modelo MaxEmerge 2, que trabalha com pressão negativa. Este encontra-se localizado dentro da roda, em plano paralelo a ela e é acionado por uma transmissão por rodas denteadas e correntes entre a roda externa e o mecanismo dosador. Para o funcionamento do mecanismo dosador é utilizado um vácuo de $4,0 \mathrm{kPa}$, obtido por um aspirador de pó acoplado ao protótipo. Quando no campo, este é acionado por um conjunto motogerador, da marca Honda, com uma potência máxima de 
1800 W. A regulagem da profundidade das covas é feita por meio de duas rodas, localizadas na barra porta ferramentas. Para a cobertura e compactação das covas são utilizadas rodas duplas dispostas em "V". O conjunto é acoplado ao trator pelo engate de três pontos.

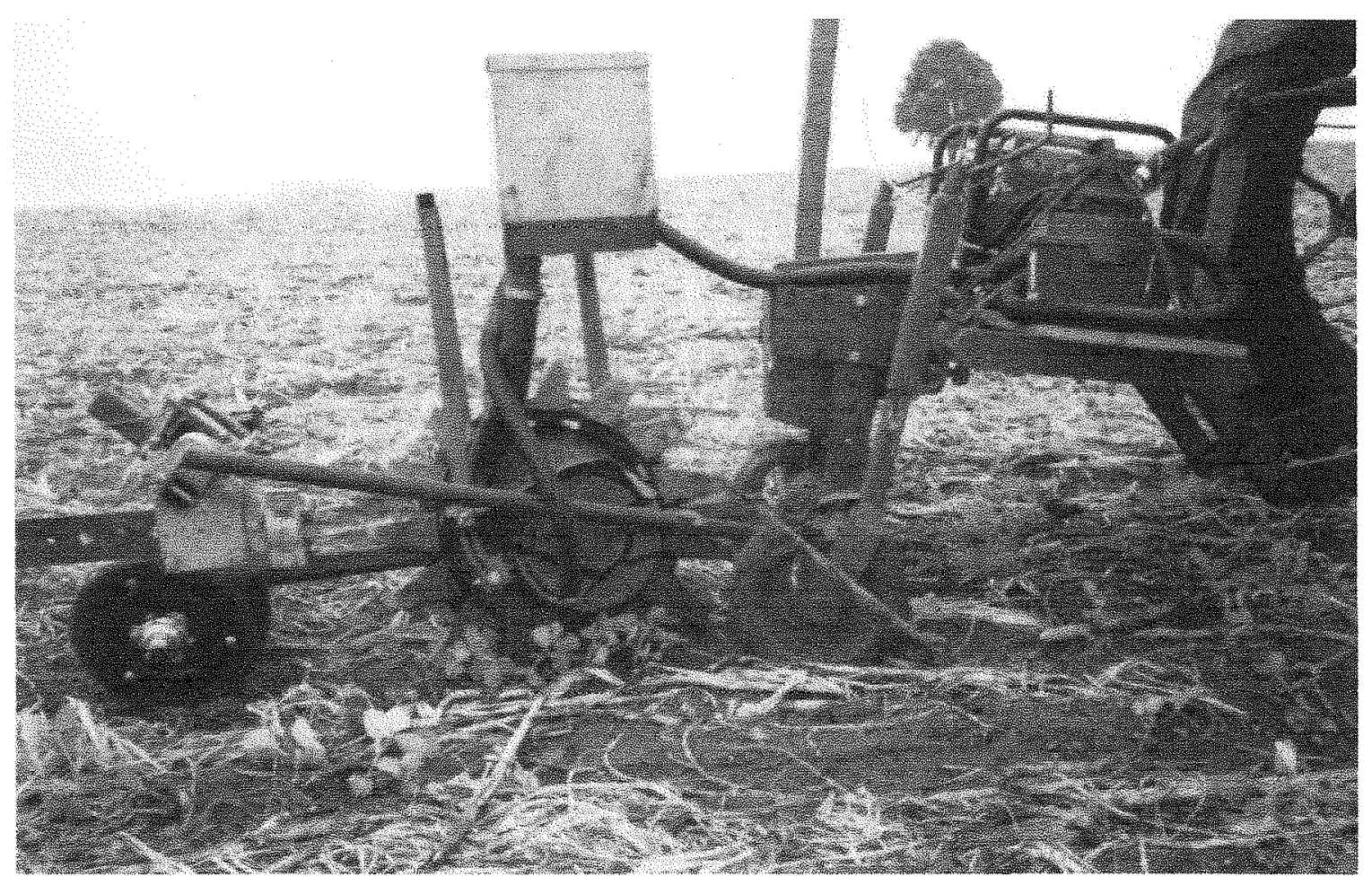

Figura 1 - Mq1, (Molin et al.,1998b), com mecanismo dosador pneumático.

As outras duas máquina foram produzidas pelo "Instituf of Landtechnik, University of Bonn", em Bonn, Alemanha, com base no trabalho de Shaw \& Kromer (1987) e disponibilizados por uma empresa brasileira para esses ensaios.

A segunda Máquina (Figura 2), designada como Mq2, conta com as seguintes características: anel de $370 \mathrm{~mm}$ de diâmetro, utilizado como suporte de 15 ponteiras com um comprimento de $140 \mathrm{~mm}$, espaçadas cada $136 \mathrm{~mm}$, distribuídas radialmente e parafusadas, dando como resultado um diâmetro 
externo de $650 \mathrm{~mm}$. Apresenta as mesmas características da Mq1 para o alojamento da semente no solo, com ângulo vertical $21^{\circ}$ e horizontal de $8^{\circ}$, respectivamente. Neste caso a máquina está equipada com um mecanismo dosador de dedos preensores, o qual é constituído por doze unidades de pequenas chapas curvas, pivotadas que se fecham sobre cada semente sob a ação de molas. $O$ acionamento dos dedos é feito por engrenagens entre a roda externa e o mecanismo dosador. A regulagem da profundidade das covas é realizada por a roda cobridora e compactadora de ferro fundido e pontas piramidais. $\mathrm{O}$ acoplamento ao trator é também do tipo montado.

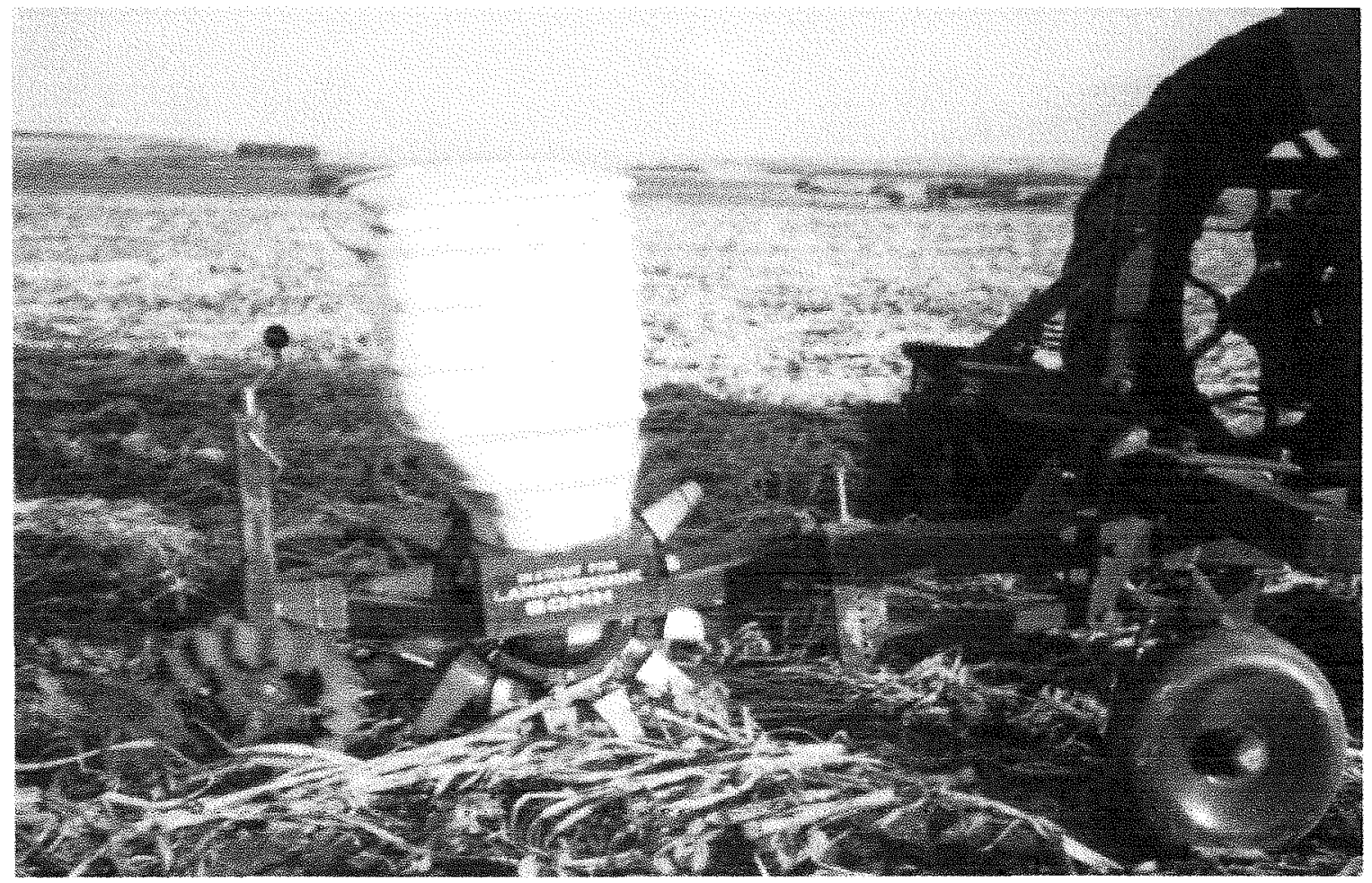

Figura 2 - Mq2, (Shaw \& Kromer, 1987), com mecanismo dosador de dedos preensores.

A terceira máquina (Figura 3), designada como Mq3, apresenta características idênticas da segunda máquina, tendo como única variação o 
mecanismo dosador, que neste caso utiliza um mecanismo tipo colher, o qual também é acionado por engrenagens. Em ambas o mecanismo dosador é instalado dentro da roda.

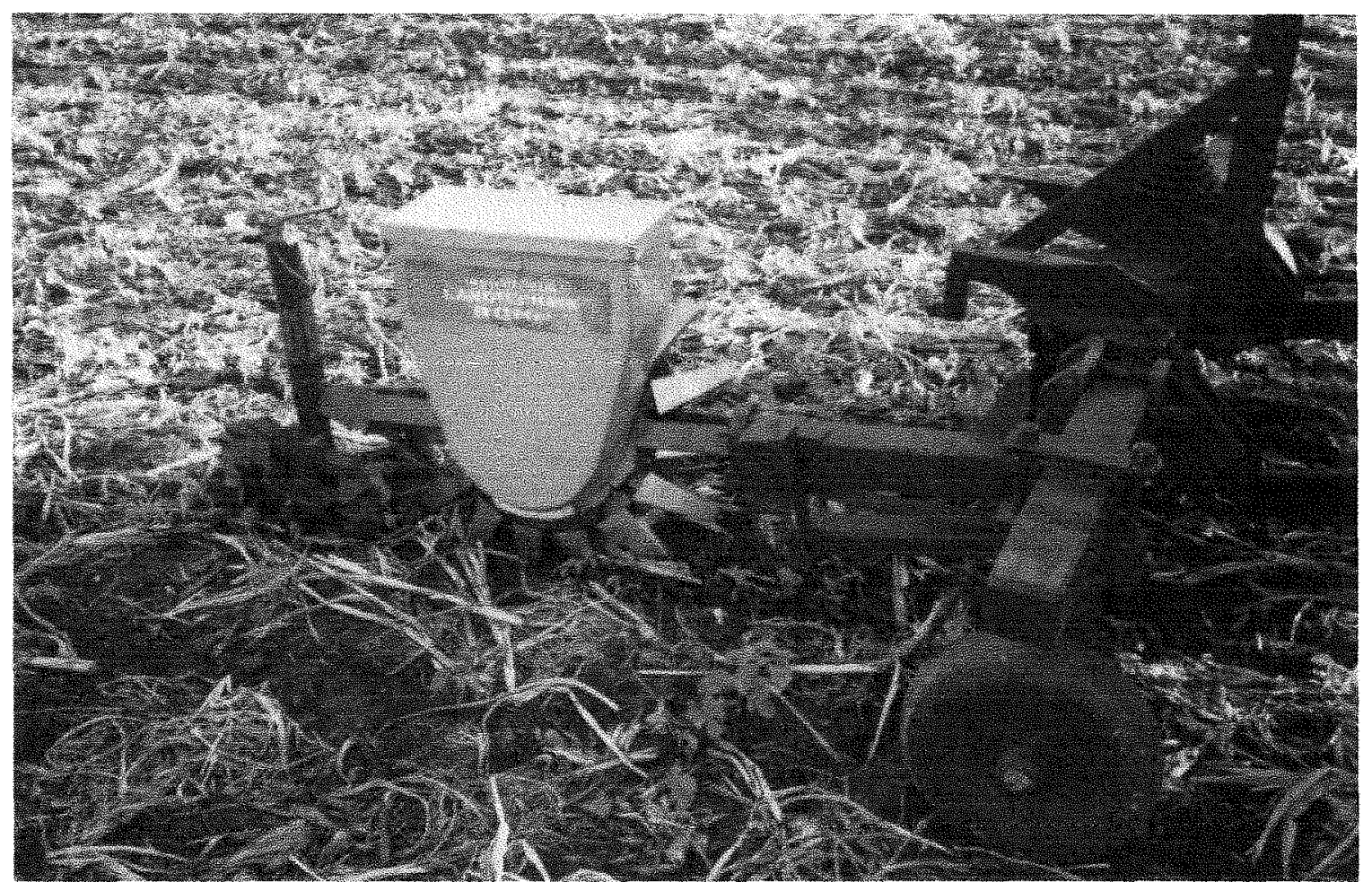

Figura 3 - Mq3, (Shaw \& Kromer, 1987), com mecanismo dosador tipo colher.

\subsection{Ensaios de Laboratório.}

A primeira etapa do trabalho visou a realização de ensaios de regularidade da distribuição longitudinal dos protótipo em laboratório, com o objetivo de avaliar a uniformidade de espaçamento entre as sementes depositadas em função da variação da velocidade. As velocidades simuladas durante a execução dos ensaios foram de $1,5 \mathrm{~m} \mathrm{~s}^{-1}\left(5,4 \mathrm{~km} \mathrm{~h}^{-1}\right) ; 2,0 \mathrm{~m} \mathrm{~s}^{-1}(7,2$ $\left.\mathrm{km} \mathrm{h}^{-1}\right)$ e $2,5 \mathrm{~m} \mathrm{~s}^{-1}\left(9,0 \mathrm{~km} \mathrm{~h}^{-1}\right)$. 
Os experimentos foram efetuados no laboratôrio de Implantação de Culturas do Departamento de Engenharia Rural da Escola Superior de Agricultura "Luiz de Queiroz" da Universidade de São Paulo, em Piracicaba, Estado de São Paulo. A metodologia adotada nos ensaios, baseou-se na Norma ISO 7256-1 (1984), embora esta não difira muito da Norma ABNT 04:015.06-004 (Associação Brasileira de Normas Técnicas, 1995).

Os ensaios foram conduzidos com auxilio de uma bancada, do tipo esteira rolante, construído no próprio departamento (Figura 4). A mesma estava equipada com um cavalete-suporte (Figura 5) para apoio e acionamento de linhas de semeadoras. A estrutura metálica da bancada possui opções de ajuste de altura e suporta uma correia plana de PVC sem emenda, com 14,5 m de extensão. A fixação das sementes na face externa da esteira é feita sobre uma camada de graxa. O movimento da esteira simula o deslocamento e a semeadora permanece estática. As transmissões de potência são efetuadas por meio de rodas denteadas e corrente, possibilitando a transmissão de movimento sincronizado. O controle da velocidade é efetuado por dois inversores de freqüência controlados por microprocessador, um na esteira e outro no cavalete-suporte. O painel foi programado para obtenção da leitura direta com controle da velocidade por potenciômetro. O cavalete-suporte para linhas de semeadoras é constituído por uma estrutura metálica, conjunto motorinversor-transmissão e possui ampla regulagem, tanto de altura como inclinação lateral e longitudinal.

Todas as máquinas foram submetidas a ensaios de bancada com a finalidade de levantar informações que possibilitassem uma definição do ponto ótimo de sincronização entre o mecanismo dosador e a roda de ponteiras. Esses ensaios foram executados para cada combinação de velocidade, de forma que nos ensaios de campo fossem utilizadas apenas essas posições. 


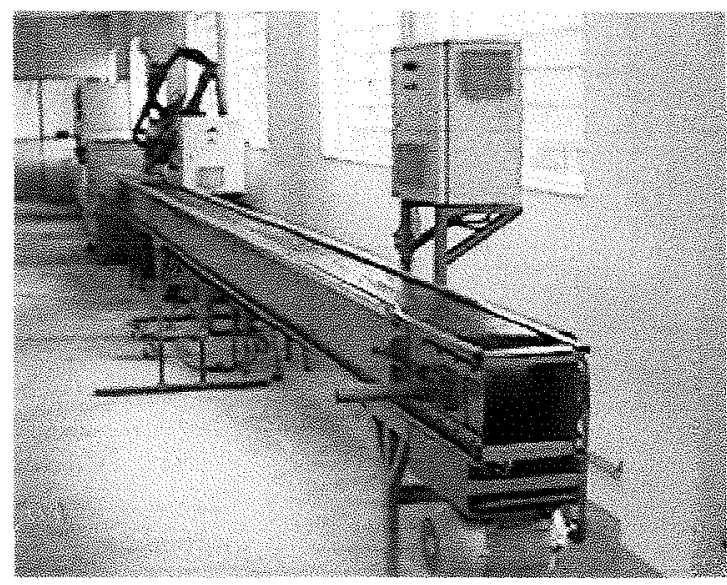

Figura 4 - Bancada de ensaio de semeadoras, tipo esteira rolante (ESALQ/USP).

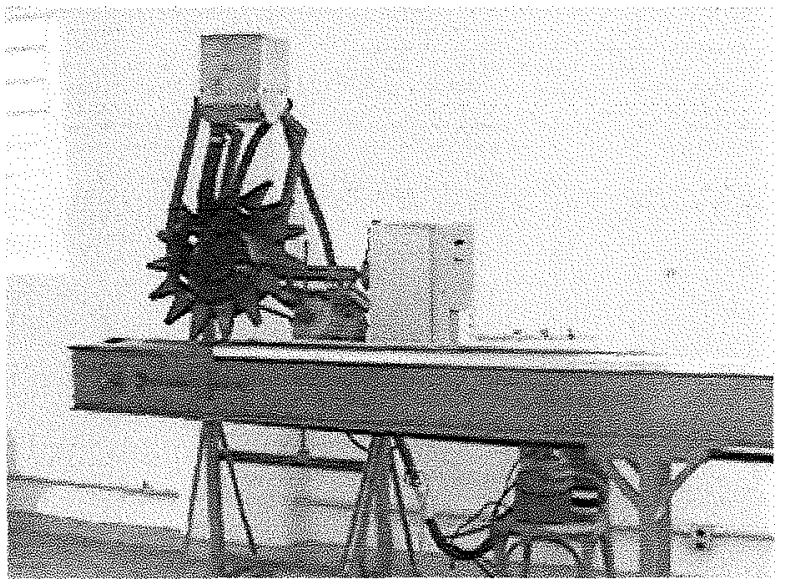

Figura 5 - Cavalete-suporte para apoio e acionamento de linhas de semeadoras (ESALQ/USP).

Preliminarmente ao início dos ensaios de laboratório, foram efetuadas modificações na Mq1, conforme sugerido por Molin (1998 b). Efetuo-se a redução na altura das aberturas laterais das extremidades das ponteiras, por onde as sementes são depositadas dentro das covas, como também no sistema de fechamento e compactação das covas.

Cada máquina apresenta características típicas de regulagem. A Mq1 permite uma ampla regulagem de posicionamento do mecanismo dosador como mostra a Figura 6, onde o ponto de lançamento da semente pode ser ajustado girando o dosador em torno de si mesmo. Tal procedimento permite aumentar significativamente a velocidade de trabalho. Entretanto, as Mq2 e Mq3 foram reguladas de forma distinta por apresentarem mecanismos dosadores fixos, com limitações na sua regulagem. Para inverter esta situação, os ajustes foram realizados por meio das rodas que sustentam as ponteiras, como pode ser observadas nas Figuras 7 e 8 . No entanto essa solução não foi considerada prática, já que era preciso desmontar as ponteiras. 


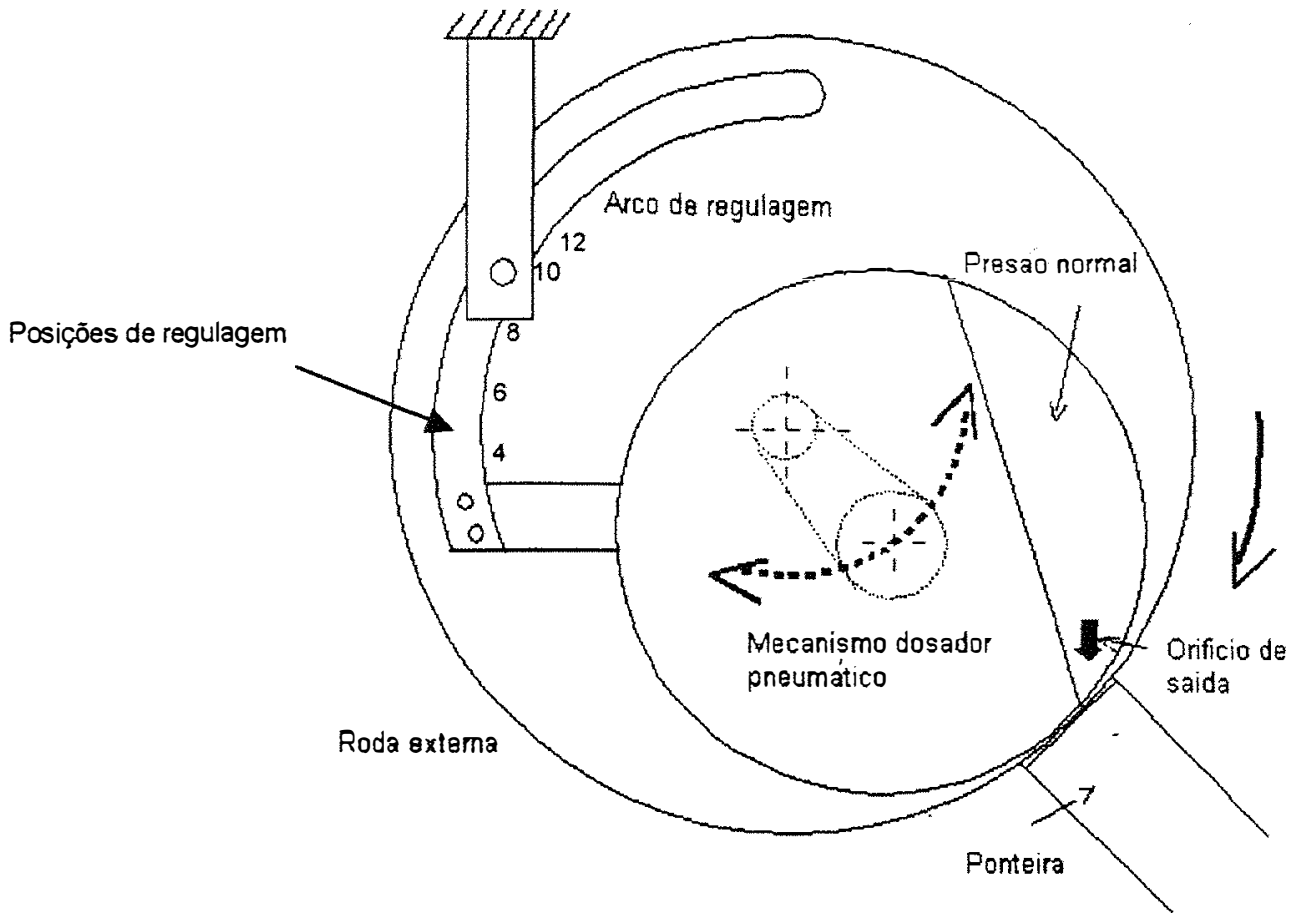

Figura 6 - Esquema do ajuste do mecanismo dosador da Mq 1 (adaptado de Molin et al., 1998).

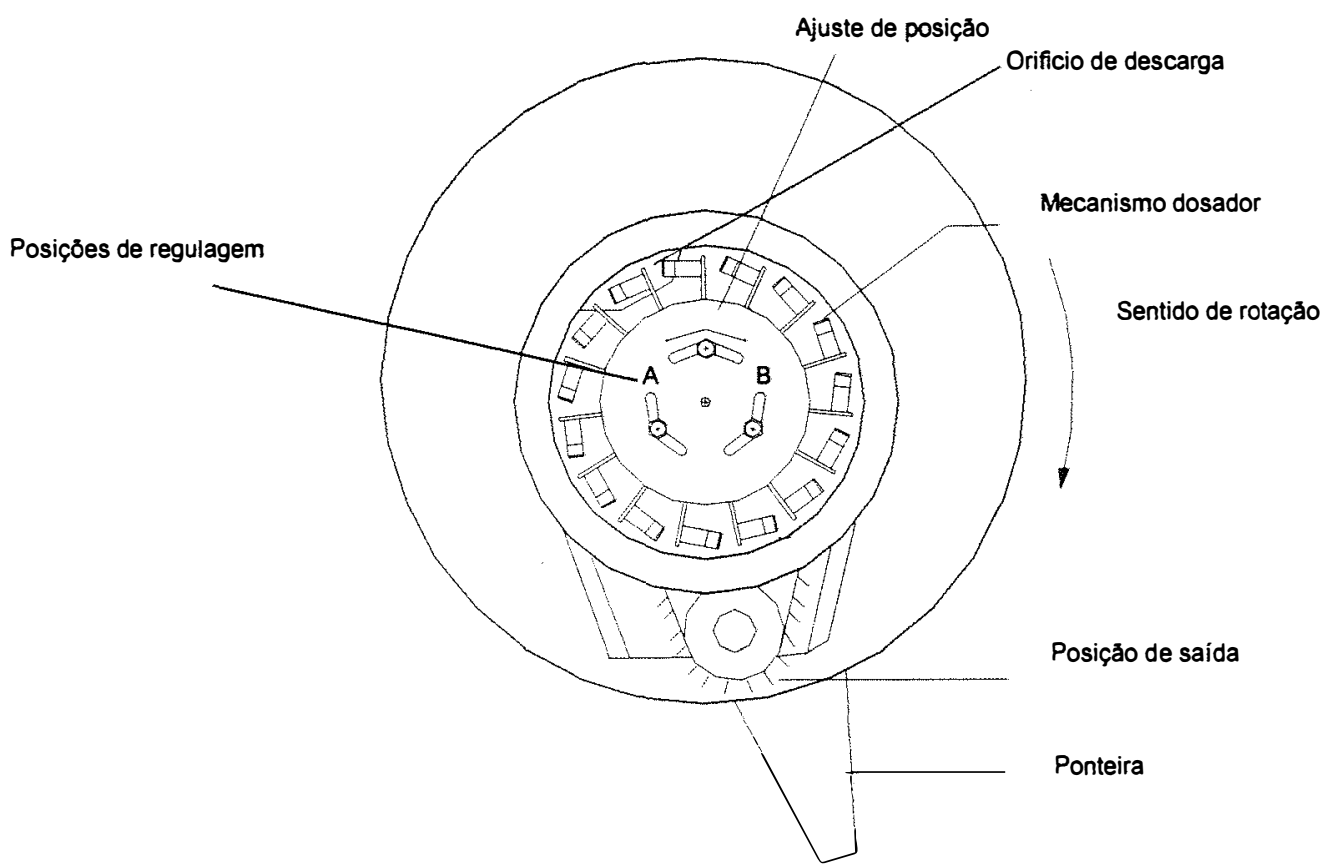

Figura 7 - Esquema do ajuste do mecanismo dosador da Mq2. 


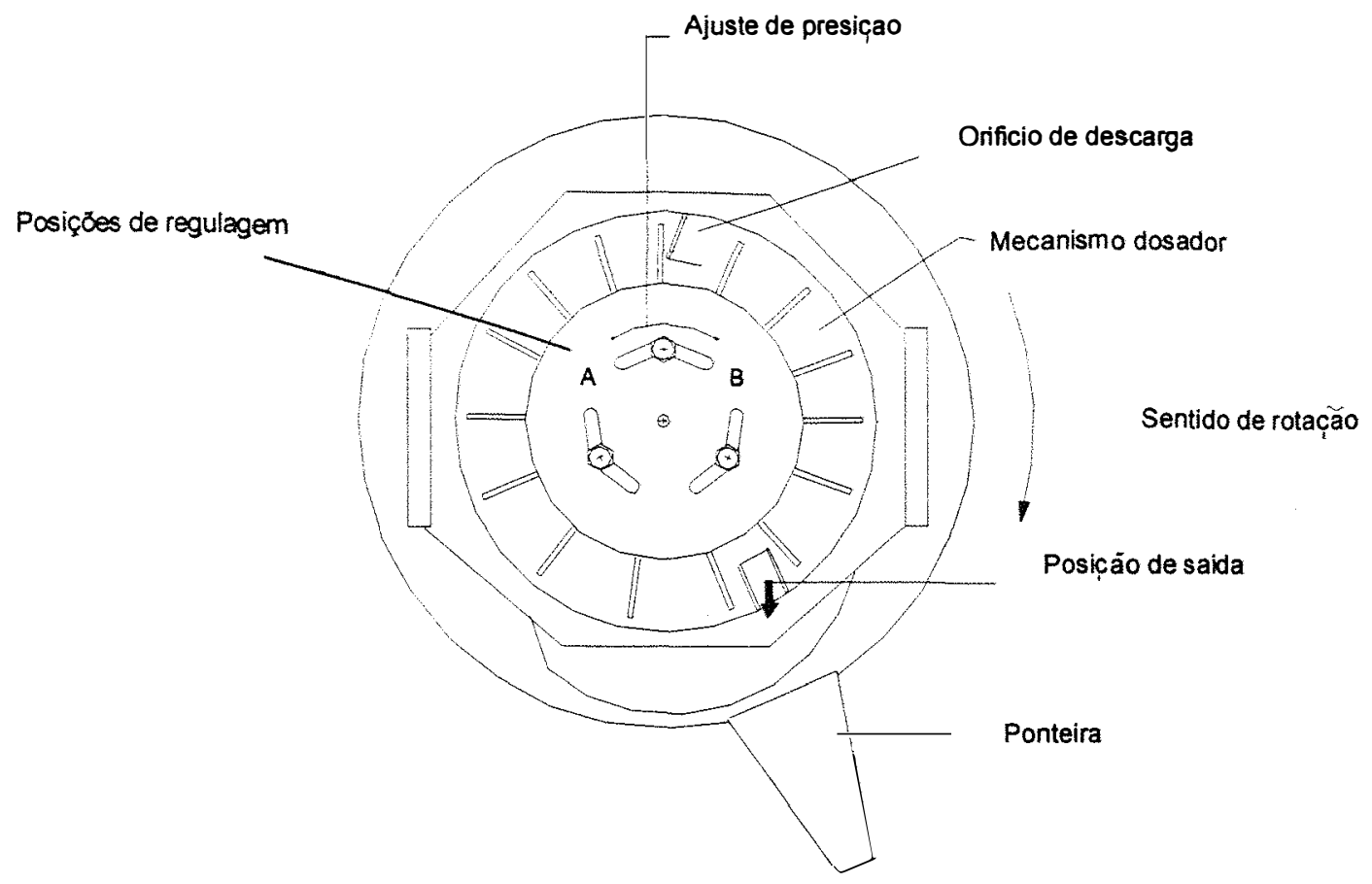

Figura 8 - Esquema do ajuste do mecanismo dosador da Mq3.

Os parâmetros utilizados para avaliar o desempenho das máquinas, foram os índices de espaçamentos normais, múltiplos e falhos, o coeficiente de variação (C.V.) e o índice de precisão.

Foram medidas as distâncias de cada semente em relação a um referencial e posteriormente transformadas, por diferença, para distância entre sementes, em uma planilha de cálculo (Excel 7.0). Na seqüência essas distâncias foram agrupadas em freqüências de espaços baseadas no espaçamento referência $\left(x_{\text {ret }}\right)$ que foi de $163 \mathrm{~mm}$ (válidas para as três máquinas), considerando-se a população de sementes e o espaçamento entre linhas. Os espaçamentos normais foram determinados conforme à norma ISO 7256-1 (1984), onde aqueles são distribuídos entre 0,5 $x_{\text {ref }}<x_{i}<1,5 x_{\text {ref; }}$; sendo múltiplos os espaços menores que $x_{i}<0,5 x_{\text {refi }}$ os intervalos maiores que $x_{i}>$ $1,5 x_{\text {ref }}$ foram considerados como falhos. 
Neste estudo, foram considerados espaçamentos normais aqueles contidos entre $68 \mathrm{~mm}$ e $204 \mathrm{~mm}$, múltiplos os menores que $68 \mathrm{~mm}$ e falhos os maiores que $204 \mathrm{~mm}$.

Foi calculado o coeficiente de variação (C.V.) levando em consideração todos os espaçamentos para expressar a regularidade dos espaçamentos entre sementes.

O índice de precisão foi obtido de acordo com o proposto pela Norma ISO 7256-1 (1984), como a relação entre o desvio padrão dos espaços normais $\left(0,5 x_{\text {ref }}<x_{i}<1,5 x_{\text {ref }}\right)$ e o espaçamento referência $\left(x_{\text {ref }}\right)$.

Posteriormente foi realizada a análise estatística apenas das posições selecionadas, onde o delineamento experimental adotado foi inteiramente casualisado, sendo utilizados os princípios da casualização e da repetição. Foi considerado um esquema fatorial $3 \times 3$, sendo três (3) máquinas e três (3) velocidades de avanço, com quatro (4) repetições. Cada rodada da esteira foi considerada uma repetição, onde coletou-se dados referentes a setenta (70) espaços. Os parâmetros estudados foram submetidos a análise da variância e, nos casos de significância do teste " $F$ " ao nível de $5 \%$ de probabilidade, efetuou-se a comparação das médias por meio do teste de Tukey (Pimentel, 1985).

Nos ensaios foram utilizadas sementes de milho Agroceres AG 405, peneira 22, tratada. No caso da Mq1, equipada com mecanismo dosador pneumático, a semente foi lubrificada com talco neutro, $50 \mathrm{~g}$ por cada reservatório, de acordo com a recomendação do fabricante (John Deere, 1993). Para as outras máquinas foram utilizados $2 \mathrm{~g}$ de grafite em $1.000 \mathrm{~g}$ de semente, sendo ideal para a lubrificação das semente de acordo com Dambrós (1998).

Uma amostra das sementes foi submetida a teste de germinação no laboratório, com o objetivo de obter informações sobre a qualidade das sementes. Os índices de germinação e os danos mecânicos nas sementes 
foram determinados de acordo com as Regras de Análise de Sementes (Brasil, 1992).

Coletou-se aleatoriamente uma amostra de aproximadamente 3.000 sementes das embalagens procedentes do fornecedor, para posterior análise. Essas, foram consideradas como testemunhas, que posteriormente foram divididas em três grupos de 1.000 sementes. Cada grupo foi chamado de: testemunha 1 sem misturar com talco ou grafite: testemunha 2 que foi misturada com talco e testemunha 3 que foi misturada com grafite.

Da mesma forma, realizou-se uma amostragem das sementes após terem passado pelos mecanismos dosadores das semeadoras. As amostras foram tomadas na mesma bancada, nas velocidades utilizadas nos ensaios de laboratório, que são as mesmas utilizadas no campo. Atingida a velocidade desejada, procedeu-se ao funcionamento do mecanismo dosador. A coleta iniciou-se após de 15 segundos, o suficiente para a estabilização operacional de cada conjunto. Utilizou-se embalagem de plástico na saída das sementes e coletou-se aproximadamente 1.000 sementes em quatro repetições, sem interromper o funcionamento do mecanismo dosador.

Todas as amostras obtidas foram separadas em 40 sub-amostras de 50 sementes por tratamento. Essas sementes foram distribuídas de forma simétrica em duas folhas de papel "germitest" e cobertas por uma terceira folha, sendo após enroladas. O papel foi previamente umedecido com um volume de água destilada equivalente a 2,5 vezes o seu peso, e colocados de forma vertical, no germinador, à temperatura de $25^{\circ} \mathrm{C}$ e umidade relativa do ar em torno de $100 \%$.

A avaliação da germinação foi realizada contando-se as plântulas normais no quarto e no sétimo dia. Considerou-se germinada a semente que demostrou aptidão para produzir planta normal obtida sob as condições e os limites de tempo especificados. Os resultados foram expressos em porcentagens, obtidos da média aritmética das sub-amostras. 
Para a coleta das sementes para a análise dos danos mecânicos foram estabelecidos os mesmos critérios utilizados na coleta das amostras destinadas para a avaliação da germinação. Coletou-se aproximadamente 600 sementes em quatro repetições, sem interromper o funcionamento do mecanismo dosador. Todas as amostras obtidas, incluindo as testemunhas misturadas com talco e com grafite, foram separadas em 24 sub-amostras de 100 sementes por tratamento. Os resultados foram expressos em porcentagem, obtidos da média aritmética das sub-amostras

O delineamento estatístico adotado para a análise de germinação e danos mecânicos, foi inteiramente casualisado, em esquema fatorial de $3 \times 2$, com quatro (4) repetições. Como já foi comentado anteriormente as sementes utilizadas na Mq1 foram lubrificadas com talco neutro e para o caso das Mq2 e Mq3 foram misturadas com grafite. Então, a Mq1 foi analisada em forma independente às Mq2 e Mq3 onde foi possivel a comparação.

Sendo assim, para a Mq1 utilizou-se três (3) velocidades de avanço e duas (2) testemunhas (testemunha sem e com talco neutro). Já para as outras máquinas o esquema fatorial foi de três (3) velocidades de avanço e duas (2) testemunhas (testemunha sem e com grafite).

Os dados obtidos de cada máquina foram submetidos ao teste " $F$ " com nível de significancia de $5 \%$, comparando-se posteriormente as médias pelo teste de Tukey ao nível de $5 \%$ de probabilidade (Pimentel, 1985).

\subsection{Ensaios de Campo}

Após a análise dos resultados da primeira fase do trabalho, foram realizados os ensaios de campo com o objetivo de avaliar o desempenho dos diferentes protótipos em condições reais de semeadura direta. Para a 
instalação e condução dos experimentos foram selecionados três (3) locais com diferentes tipos de solo e resíduo.

A primeira área era localizada na Fazenda Areão, pertencente à Escola Superior de Agricultura "Luiz de Queiroz" da Universidade de São Paulo, cidade de Piracicaba, Estado de São Paulo, cujas coordenadas geográficas são: $22^{\circ} 42^{\prime} 30^{\prime \prime}$ Latitude Sul, 470 38' 00" Longitude Oeste e altitude de 546 m. O clima da região é o Cwa, de Köppen (1940), mesotérmico, com chuva no verão e inverno seco, com uma média anual de $1.247 \mathrm{~mm}$ de precipitação e temperatura média de $21,2{ }^{\circ} \mathrm{C}$. O solo está classificado como Terra Roxa estruturada (Alfisol), série "Luiz de Queiroz", com predominância da fração argila. A área experimental apresentava uma superfície plana. No momento da semeadura, o solo estava coberto por residuo de milheto (Pericetum americanum L.) seco e ligeiramente infestado de capim colonião (Panicum maximum). A área estava sendo manejada com cobertura verde, após ter sido colhida soja (Glycine max (L.) Merril).

A segunda área experimental foi implantada no município de Campos Novos Paulista, Estado de São Paulo, cujas coordenadas geográficas são: $22^{\circ}$ $41^{\prime} 58^{\prime \prime}$ Latitude Sul, 49 $58^{\prime} 47^{\prime \prime}$ Longitude Oeste e altitude de $446 \mathrm{~m}$. O clima da região é Cwa, mesotérmico, chuva no verão e seca no inverno conforme classificação de Köppen (1940), com uma temperatura média anual de $22,2^{\circ} \mathrm{C}$ e precipitação média anual $1.345 \mathrm{~mm}$. O solo, classificado como Podzólico Vermelho Amarelo álico a moderado com textura média ou arenosa/média. A área apresentava um relevo relativamente plano, sendo manejado em sistema de plantio direto (milho-soja). Na ocasião da instalação do experimento, o solo encontrava-se coberto por massa de palha de milho (Zea mays L.) e resíduo de soja (Glycine max (L.) Merril).

O último local de ensaio foi no município de Pirassununga, Estado de São Paulo, cujas coordenadas geográficas são: $21^{\circ} 59^{\prime} 01^{\prime \prime}$ Latitude Sul, $47^{\circ}$ 26' 06" Longitude Oeste e altitude de 627 m. A região possui clima temperado 
quente, tipo savana, com inverno - seco e verão quente e chuvoso, tipo Cwa, conforme classificação de Köppen (1940), com uma temperatura média anual de $20,8^{\circ} \mathrm{C}$ e precipitação média anua $1.248 \mathrm{~mm}$. O trabalho foi realizado num Latossolo Vermelho Escuro álico a moderado, textura média, em relevo plano. O solo estava sendo manejado em sistema de plantio direto, em rotação de milho e soja. A área encontrava-se coberta por uma massa de palha de milho (Zea mays L.) e capim colonião (Panicum maximum).

Por ocasião da instalação dos experimentos as três áreas experimentais foram dessecadas com a aplicação de herbicida de principio ativo Glyphosate, para evitar a possibilidade de infestação de ervas daninhas durante os ensaios.

Antes do início dos ensaios de campo foi feita a caracterização de cada área experimental. Foram coletadas amostras não deformadas de solo com martelo AMS e anéis metálicos de $48 \mathrm{~mm}$ de diâmetro e $45 \mathrm{~mm}$ de altura para determinação da densidade. Para cada unidade experimental foram obtidas oito (8) amostras para densidade, sendo quatro (4) na faixa de 0 a $0,05 \mathrm{~m}$ de profundidade e as outras quatro (4) na faixa de $0,05 \mathrm{~m}$ a $0,10 \mathrm{~m}$ de profundidade. $O$ valor da densidade do solo foi estabelecido pela relação entre a massa do solo seca em estufa a $105^{\circ} \mathrm{C}$ por 36 horas e pelo volume contido no anel metálico (Embrapa, 1979).

O teor de água no solo foi determinado durante as fases de avaliação da densidade do solo, no mesmo dia da semeadura. A umidade do solo foi obtida pelo método gravimétrico, em função da relação entre a massa de solo contida numa amostra sobre a massa da amostra seca em estufa a $105^{\circ} \mathrm{C}$ por 36 horas.

A avaliação do percentual de cobertura vegetal do solo foi determinada pelo método da trena, proposto por Laflen et al. (1981). Esticou-se a trena em vinte e quatro (24) locais diferentes; selecionados aleatoriamente, visando obter uma amostragem geral de cada área experimental. 
Para a determinação da matéria seca utilizou-se o método de pesagem de amostras. Coletou-se aleatoriamente doze (12) amostras da palha distribuídas sobre o solo da área experimental, utilizando-se um quadro de dimensões de $0,5 \mathrm{~m} \times 0,5 \mathrm{~m}\left(0,25 \mathrm{~m}^{2}\right)$. Fez-se a secagem do material em estufa a $65^{\circ} \mathrm{C}$ por 24 horas. Após a secagem, a massa foi convertida para toneladas por hectare.

A resistência do solo à penetração no perfil foi determinada pelo índice de cone (IC), com o gráfico traçado pelo penetrógrafo de registro continuo, da marca Penetrographer SC-60, equipado com um cone de $12,83 \mathrm{~mm}$ de diâmetro, como normalizado pela ASAE S 313.1, (1983). Este procedimento foi realizado antes da semeadura. As mediçōes foram feitas até a profundidade de $0,55 \mathrm{~m}$. Realizaram-se trinta e seis (36) amostras em uma área de $1.440 \mathrm{~m}^{2}$, sendo doze (12) amostras referente à área de cada máquina. Os valores registrados em $\mathrm{kgf}_{\mathrm{cm}} \mathrm{cm}^{-2}$ nos gráficos foram convertidos para $\mathrm{kPa}$.

Em cada um dos locais foi demarcada uma área $1.440 \mathrm{~m}^{2}$, com $40 \mathrm{~m}$ de comprimento e $36 \mathrm{~m}$ de largura, o suficiente para avaliar as três máquinas em um percurso de ida. Adotou-se como bordadura os 10 metros iniciais, destinados à estabilização da velocidade do conjunto trator-semeadora e os 5 $\mathrm{m}$ finais destinados à desaceleração do conjunto. Na cabeceira da parcela manteve-se uma área livre de $3 \mathrm{~m}$, destinada a manobras do conjunto. Cada máquina foi avaliada em três velocidades de trabalho: $1,5 \mathrm{~m} \mathrm{~s}^{-1}\left(5,4 \mathrm{~km} \mathrm{~h}^{-1}\right) ; 2,0$ $\mathrm{m} \mathrm{s}^{-1}\left(7,2 \mathrm{~km} \mathrm{~h}^{-1}\right)$ e $2,5 \mathrm{~m} \mathrm{~s}^{-1}\left(9,0 \mathrm{~km} \mathrm{~h}^{-1}\right)$.

O delineamento estatístico adotado foi o mesmo utilizado nos ensaios de laboratório; ou seja inteiramente casualizado com um fatorial de $3 \times 3$, com nove (9) tratamentos e quatro (4) repetições, distribuídas aleatoriamente em cada área experimental.

A avaliação da uniformidade de distribuição longitudinal das sementes de cada tratamento foi realizada após trinta dias de semeadura e teve como 
base os parâmetros já utilizados anteriormente no laboratório. Em cada repetição foram medidos setenta (70) espaçamentos entre plantas.

Para cada experimento foi conduzida uma análise de variância para os índices de normais, múltiplos, falhas, coeficiente de variação (C.V.) e indice de precisão, verificando-se a significância de seus efeitos. Na comparação das médias utilizou-se o testes de Tukey, ao nível de $5 \%$ de probabilidade.

Nos ensaios de campo foram utilizadas sementes de milho (Zea mays L.), cultivar AG 405 da Agroceres, híbrido duplo, de ciclo precoce, com pureza mínima de 99 \% e peneira de classificação número 22. Também foi adicionado talco e grafite no momento da semeadura, com doses de acordo com os critérios adotados nos ensaios de bancada. 


\section{RESULTADOS E DISCUSSÃO}

\subsection{Ensaios de laboratório}

Os ensaios de laboratórios a que foram submetidas as três máquinas, visaram avaliar as possíveis posições de queda das sementes do mecanismo dosador para cada combinação de velocidade. Na Tabela 1 são apresentados os resultados de distribuição longitudinal de ajuste para a Mq1, para as velocidades de avanço de $1,5 \mathrm{~m} \mathrm{~s}^{-1}, 2,0 \mathrm{~m} \mathrm{~s}^{-1}$ e $2,5 \mathrm{~m} \mathrm{~s}^{-1}$. Para cada velocidade foram ensaiadas o maior número de posições possíveis na máquina.

Observa-se na Figura 9 o resultado do ensaio de ajuste para a velocidade de $1,5 \mathrm{~m} \mathrm{~s}^{-1}$, o qual revelou que a posição número 4 apresentou menor limitação quanto à posição de queda das sementes do mecanismo dosador com as ponteiras. Observa-se que a partir desta posição a porcentagem de normais foi diminuindo, sendo mais visível na posição 7 , em que foram observados valores elevados para todos os parâmetro analisados. $A$ posição 4 apresentou o menor coeficiente de variação em comparação com as demais posições. Também apresentou a melhor precisão, embora o resultado obtido não esteja distante das demais posições. 
Tabela 1. Resultado dos ensaios da regularidade de distribuição longitudinal de sementes em bancada de laboratório para a Mq1.

\begin{tabular}{ccccccc}
\hline \multicolumn{7}{c}{ Mq1 (mecanismo dosador pneumático) } \\
\hline Posições de & Velocidade & Múltiplos & Normais & Falhos & C.V. & Precisão \\
Regulagem & $\left(\mathrm{m} \mathrm{s}^{-1}\right)$ & $(\%)$ & $(\%)$ & $(\%)$ & $(\%)$ & $(\%)$ \\
\hline 4 & & 2,8 & 96,1 & 1,1 & 19,6 & 10,2 \\
5 & 1,5 & 2,8 & 95,4 & 1,8 & 22,4 & 10,9 \\
6 & & 3,9 & 94,7 & 1,4 & 24,3 & 11,8 \\
7 & & 10,4 & 83,6 & 6,0 & 43,5 & 11,7 \\
\hline 4 & & 2,9 & 95,7 & 1,4 & 21,2 & 8,1 \\
5 & & 5,7 & 92,5 & 1,8 & 23,6 & 7,2 \\
6 & & 2,2 & 96,4 & 1,4 & 18,1 & 7,1 \\
7 & 2,0 & 3,9 & 95,0 & 1,1 & 22,8 & 7,1 \\
8 & & 2,9 & 94,6 & 2,5 & 24,8 & 7,7 \\
9 & & 3,2 & 94,6 & 2,2 & 22,4 & 7,1 \\
10 & & 2,9 & 94,3 & 2,8 & 32,5 & 8,2 \\
\hline 4 & & 4,3 & 88,2 & 7,5 & 37,1 & 13,0 \\
5 & & 1,8 & 93,2 & 5,0 & 25,4 & 9,4 \\
6 & & 4,3 & 92,1 & 3,6 & 27,9 & 7,9 \\
7 & & 2,8 & 93,6 & 3,6 & 27,2 & 12,0 \\
8 & 2,5 & 4,6 & 91,5 & 3,9 & 28,5 & 7,6 \\
9 & & 1,8 & 95,4 & 2,8 & 20,8 & 7,3 \\
10 & & 2,5 & 93,9 & 3,6 & 24,1 & 7,2 \\
11 & & 2,5 & 92,9 & 4,6 & 24,8 & 6,7 \\
12 & & 3,6 & 83,5 & 12,9 & 43,6 & 8,1 \\
\hline
\end{tabular}

$\mathrm{Na}$ Figura 10, apresenta-se os resultados do ajustes para a velocidade de $2,0 \mathrm{~m} \mathrm{~s}^{-1}$. Observar-se que a melhor sincronização obtida para o mecanismo dosador e as ponteiras foi a posição número 6 , a qual revelou o menor coeficiente de variação e a melhor precisão em comparação com as demais posições. Pode-se observar que as porcentagens obtidas nas outras posições não estiveram longe do valor registrado nesta posição, embora nas posições 8 
a 10 observou-se uma diminuição nos índices de normais. Em contra posição os índices de múltiplos e falhas aumentaram. O mesmo aconteceu com o coeficiente de variação e a precisão. Também é possível observar que na posição 6 a porcentagem de falha registrada não foi a mais baixa.

Velocidade de $1,5 \mathrm{~m} \mathrm{~s}^{-1}$ (Mq1)

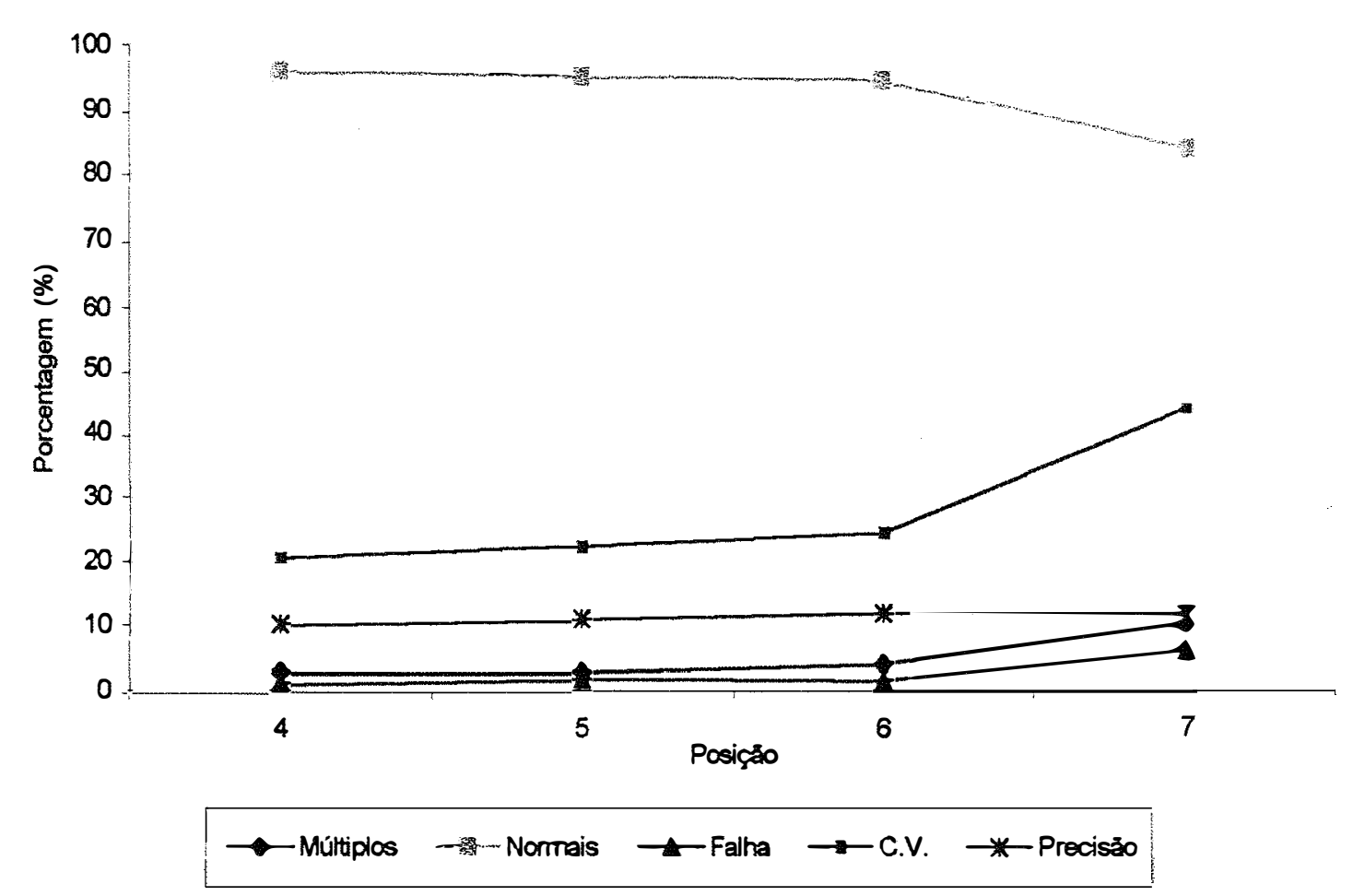

Figura 9 - Resultado do ensaio da regularidade de distribuição longitudinal de sementes em bancada de laboratório para a Mq1 para a velocidade de $1,5 \mathrm{~m} \mathrm{~s}^{-1}$.

Na última velocidade ensaiada (Figura 11), o melhor ajuste obtido foi na posição 9, que apresentou menor limitação quanto à posição de queda das sementes do mecanismo dosador com a roda de ponteiras. Os resultados obtidos nas outras posições não possibilitaram observar uma tendência dos 
indices de normais com a variação das posições para esta velocidade. 0 coeficiente de variação também foi o mais baixo. Já a precisão não apresentou grande variação.

Velocidade de 2,0 $\mathrm{m} \mathrm{s}^{-1}$ (Mq1)

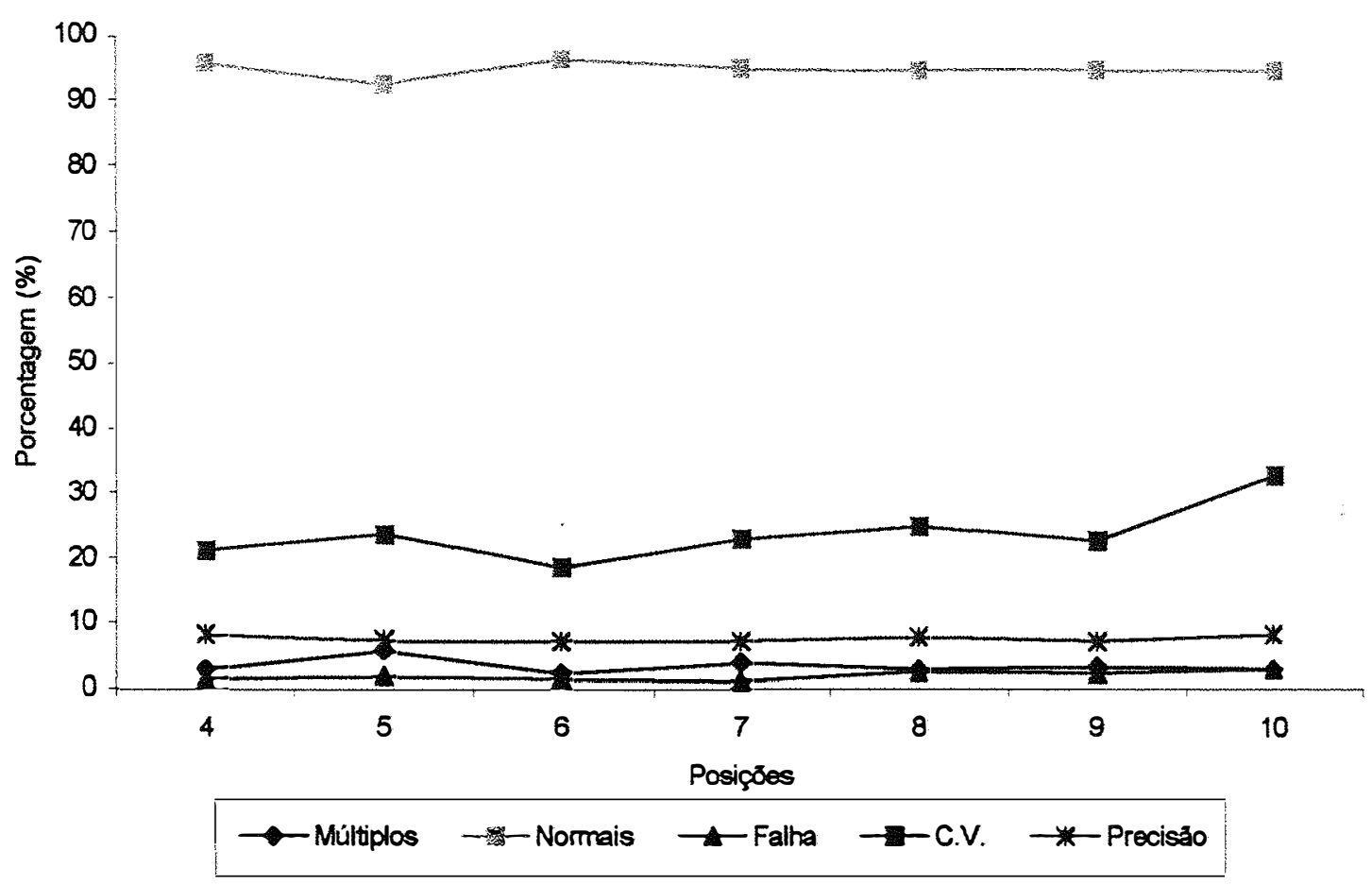

Figura 10 - Resultado do ensaio da regularidade de distribuição longitudinal de sementes em bancada de laboratório para a Mq1 para a velocidade de $2,0 \mathrm{~m} \mathrm{~s}^{-1}$.

No caso das Mq2 e Mq3, devido às limitações de regulagem, somente foi possível selecionar duas posições além da posição original. Como as duas 
máquinas apresentaram as mesmas configurações, a exceção do mecanismo dosador, essas duas posições foram designadas como posições $A$ e B.

Velocidade de $2,5 \mathrm{~m} \mathrm{~s}^{-1}$ (Máquina 1)

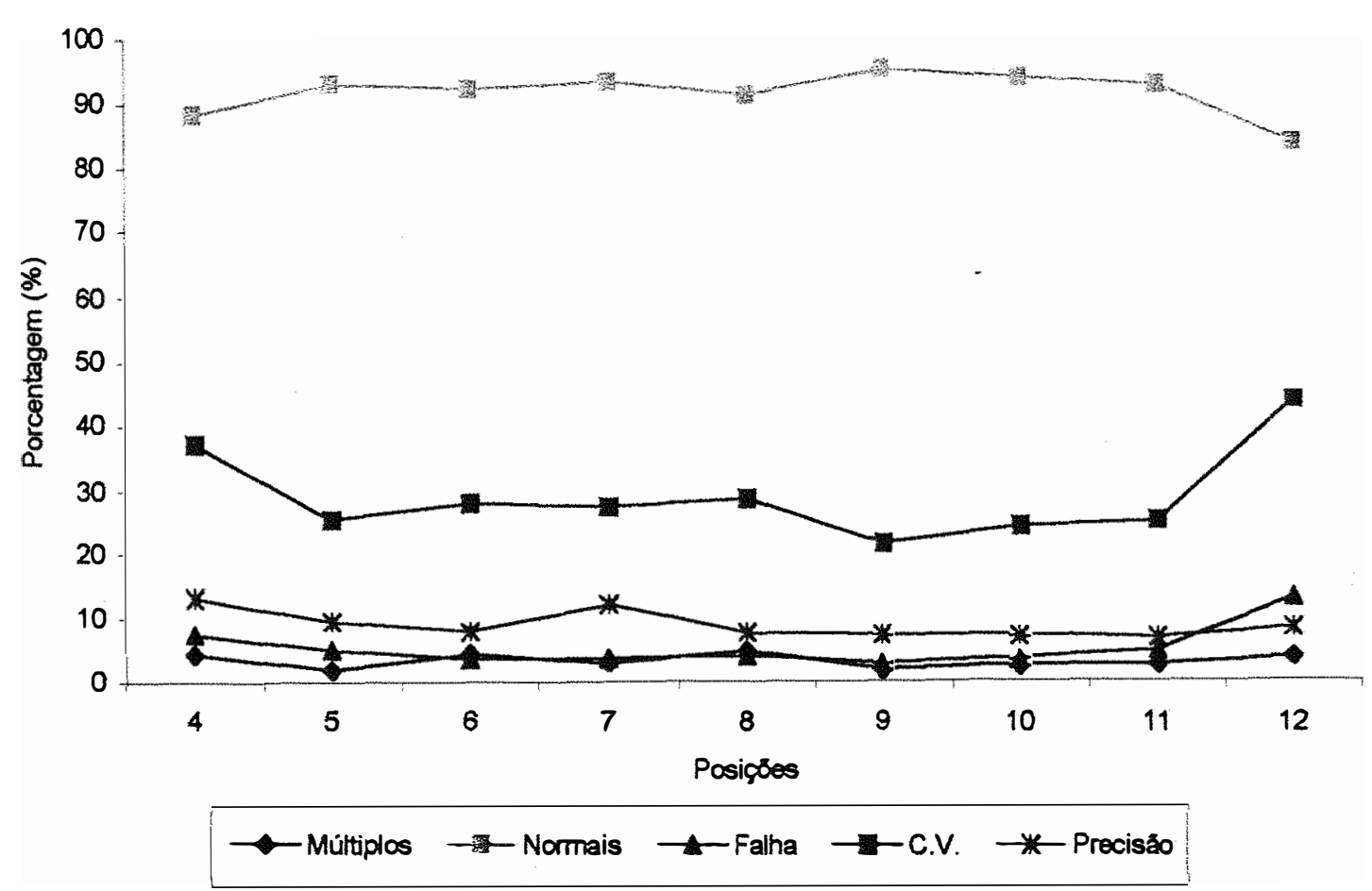

Figura 11 - Resultado do ensaio da regularidade de distribuição longitudinal de sementes em bancada de laboratório para a Mq1 para a velocidade de $2,5 \mathrm{~m} \mathrm{~s}^{-1}$.

Na Tabela 2 são apresentados os resultados dos ensaios de ajuste para a Mq2, para as velocidades de avanço de $1,5 \mathrm{~m} \mathrm{~s}^{-1}, 2,0 \mathrm{~m} \mathrm{~s}^{-1}$ e $2,5 \mathrm{~m} \mathrm{~s}^{-1}$. 
De forma geral, é possível observar que os ajustes deram resultado positivo no desempenho em comparação com a posição original.

Tabela 2. Resultado dos ensaios da regularidade de distribuição longitudinal de sementes em bancada de laboratório para a Mq2.

Mq2 (mecanismo dosador de dedos preensores)

\begin{tabular}{ccccccc}
\hline $\begin{array}{c}\text { Posições de } \\
\text { Regulagem }\end{array}$ & $\begin{array}{c}\text { Velocidade } \\
\left(\mathrm{m} \mathrm{s}^{-1}\right)\end{array}$ & $\begin{array}{c}\text { Múltiplos } \\
(\%)\end{array}$ & $\begin{array}{c}\text { Normais } \\
(\%)\end{array}$ & $\begin{array}{c}\text { Falhos } \\
(\%)\end{array}$ & $\begin{array}{c}\text { C.V. } \\
(\%)\end{array}$ & $\begin{array}{c}\text { Precisão } \\
(\%)\end{array}$ \\
\hline Original & \multirow{2}{*}{1,5} & 2,5 & 77,9 & 19,6 & 47,1 & 13,4 \\
A & 4,3 & 78,9 & 16,8 & 42,5 & 21,3 \\
B & & 2,8 & 86,1 & 11,1 & 37,5 & 7,8 \\
\hline Original & \multirow{2}{*}{2,0} & 10,7 & 56,4 & 32,9 & 60,8 & 16,7 \\
A & 2,1 & 85,0 & 12,9 & 39,3 & 14,6 \\
B & & 2,5 & 88,6 & 8,9 & 32,3 & 9,7 \\
\hline Original & \multirow{2}{*}{2,5} & 11,8 & 54,6 & 33,6 & 74,8 & 23,3 \\
A & 4,3 & 87,8 & 7,9 & 34,5 & 11,3 \\
B & & 5,0 & 90,0 & 5,0 & 30,4 & 10,8 \\
\hline
\end{tabular}

Observa-se na Figura 12, os resultados dos ensaios, para a velocidade de $1,5 \mathrm{~m} \mathrm{~s}^{-1}$. A regulagem que melhor sincronização apresentou entre o mecanismo dosador e a roda externa com as ponteiras, foi a posição B. O índice de espaços normais foi mais elevado, o coeficiente de variação foi o mais baixo, como também foi obtida a melhor precisão em comparação com as demais posições ensaiadas. 
Velocidade de $1,5 \mathrm{~m} \mathrm{~s}^{-1}\left(\mathrm{Mq}^{2}\right)$

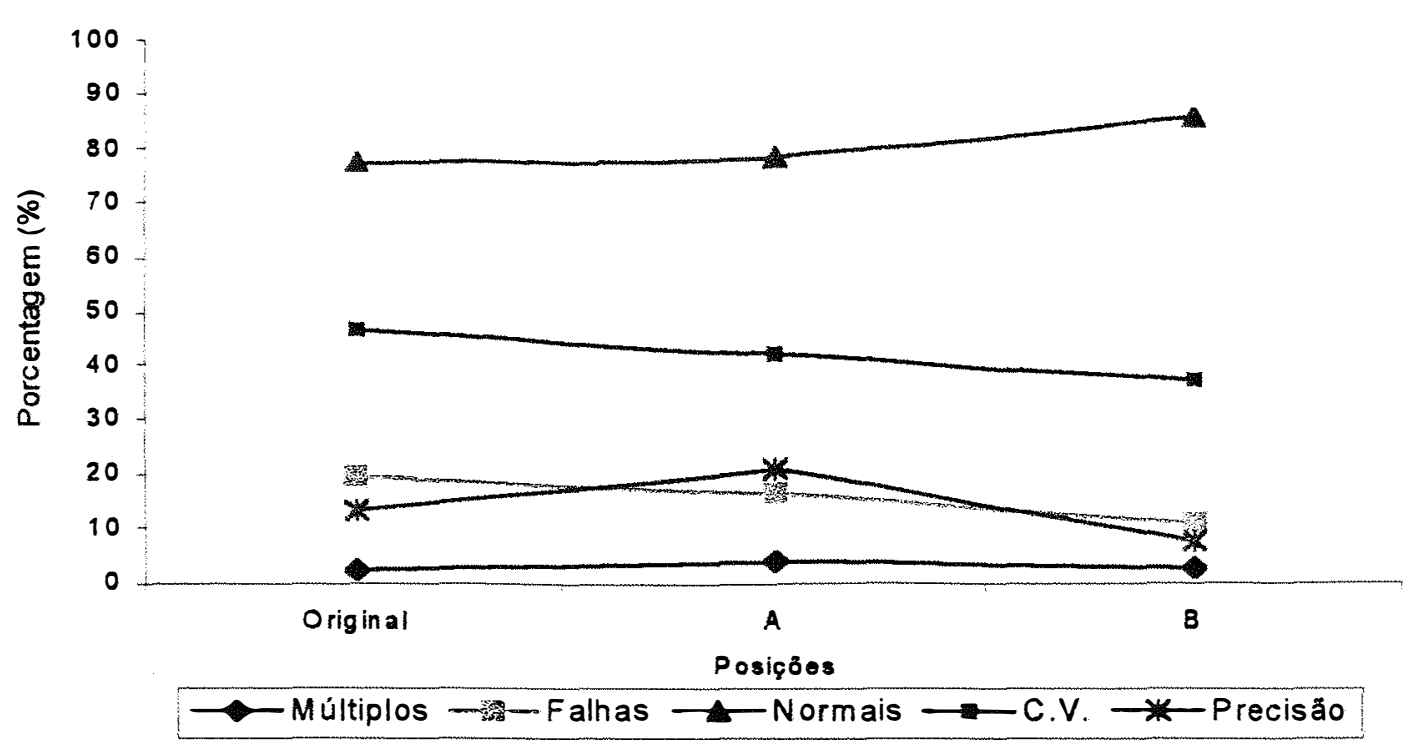

Figura 12 - Resultado do ensaio da regularidade de distribuição longitudinal de sementes em bancada de laboratório para a Mq2 para a velocidade de $1,5 \mathrm{~m} \mathrm{~s}^{-1}$.

Na Figura 13 são apresentados os resultados de ajuste para a velocidade de $2,0 \mathrm{~m} \mathrm{~s}^{-1}$, onde pode observar-se que a melhor sincronização obtida para o mecanismo dosador e as ponteiras foi a posição $B$, a qual apresenta o maior índice de espaços normais, o menor coeficiente de variação e a melhor precisão em comparação com as demais. Pode-se ressaltar que 0 desempenho registrado na posição original para os índices de normais foi baixo em comparação com os resultados atingidos na posição $A$ e sobretudo com na posição $B$. 


\section{Velocidade de $2,0 \mathrm{~m} \mathrm{~s}^{-1}$ (Mq2)}

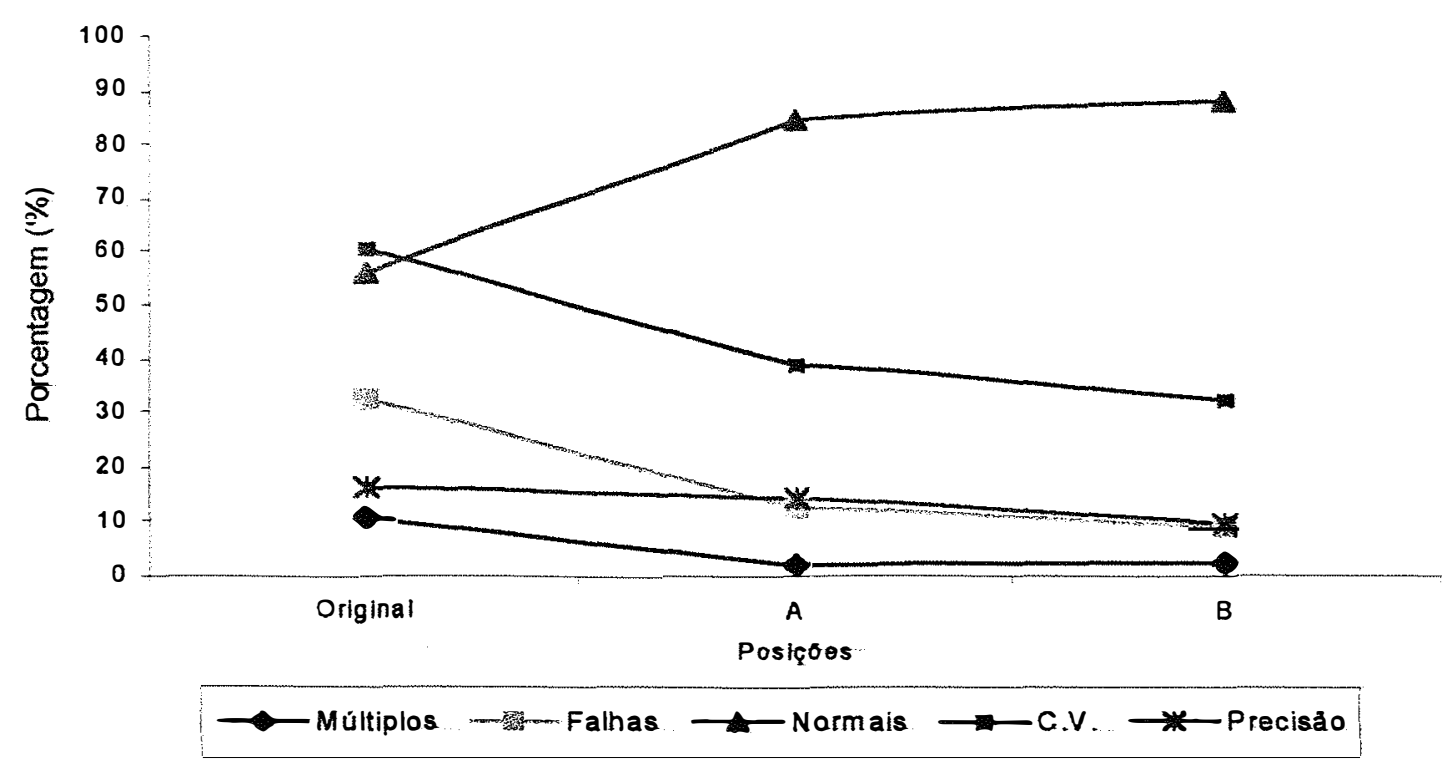

Figura 13 - Resultado do ensaio da regularidade de distribuição longitudinal de sementes em bancada de laboratório para a Mq2 para a velocidade de $2,0 \mathrm{~m} \mathrm{~s}^{-1}$.

$\mathrm{Na}$ Figura 14 são apresentados os resultados de ajuste para a velocidade de $2,5 \mathrm{~m} \mathrm{~s}^{-1}$, onde pode-se observar que a melhor sincronização obtida para o mecanismo dosador e as ponteiras foi a posição B. Essa, revelou o maior índice de espaços normais, o menor coeficiente de variação e a melhor precisão em comparação com as demais. Também neste caso observou-se 0 acontecido na velocidade de $2,0 \mathrm{~m} \mathrm{~s}^{-1} \mathrm{em}$ que os resultados obtidos na posição original foi baixo em comparação com as posições $A$ e $B$. 


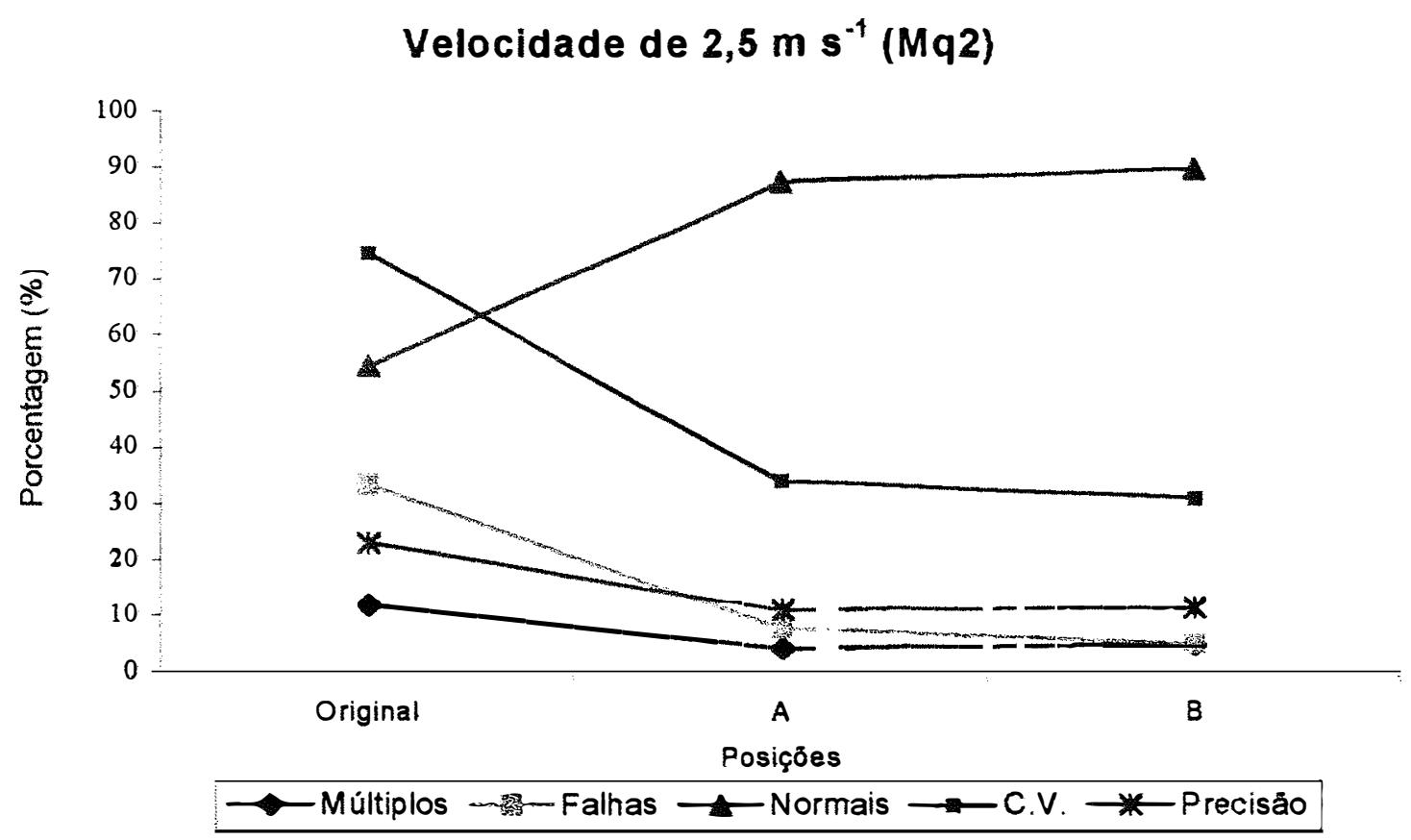

Figura 14 - Resultado do ensaio da regularidade de distribuição longitudinal de sementes em bancada de laboratório para a Mq2 para a velocidade de $2,5 \mathrm{~m} \mathrm{~s}^{-1}$.

Na Tabela 3 são apresentados os resultados dos ensaios da Mq3, para as velocidades de avanço de $1,5 \mathrm{~m} \mathrm{~s}^{-1} ; 2,0 \mathrm{~m} \mathrm{~s}^{-1}$ e $2,5 \mathrm{~m} \mathrm{~s}^{-1}$. Observa-se que os ajustes realizados na $\mathrm{Mq3}$ não resultaram em grande impacto no desempenho da mesma com o aumento da velocidade de avanço, provavelmente devido a deficiências do mecanismo dosador na individualização das sementes. 
Tabela 3. Resultado dos ensaios da regularidade de distribuição longitudinal de sementes em bancada de laboratório para a Mq3.

Mq3 (mecanismo dosador tipo colher)

\begin{tabular}{ccccccc}
\hline $\begin{array}{c}\text { Posições de } \\
\text { Regulagem }\end{array}$ & $\begin{array}{c}\text { Velocidade } \\
\left(\mathrm{m} \mathrm{s}^{-1}\right)\end{array}$ & $\begin{array}{c}\text { Múltiplos } \\
(\%)\end{array}$ & $\begin{array}{c}\text { Normais } \\
(\%)\end{array}$ & $\begin{array}{c}\text { Falhos } \\
(\%)\end{array}$ & $\begin{array}{c}\text { C.V. } \\
(\%)\end{array}$ & $\begin{array}{c}\text { Precisão } \\
(\%)\end{array}$ \\
\hline $\begin{array}{c}\text { Original } \\
\text { A }\end{array}$ & \multirow{2}{*}{1,5} & 3,6 & 93,9 & 2,5 & 24,7 & 8,6 \\
B & & 4,3 & 92,1 & 3,6 & 28,2 & 11,8 \\
Original & \multirow{2}{*}{2,0} & 5,4 & 88,9 & 5,7 & 34,0 & 11,5 \\
A & & 5,4 & 87,1 & 6,5 & 36,2 & 11,7 \\
B & & 5,0 & 92,1 & 2,9 & 28,2 & 11,0 \\
Original & \multirow{2}{*}{2,5} & 6,1 & 80,7 & 4,3 & 32,5 & 20,1 \\
A & 6,8 & 85,0 & 8,2 & 38,4 & 15,9 \\
B & & 8,6 & 84,3 & 7,1 & 40,2 & 16,7 \\
\hline
\end{tabular}

Observou-se na Figura 15, que para a velocidade $1,5 \mathrm{~m} \mathrm{~s}^{-1}$, o melhor ajuste foi na posição original, o qual apresentou menor limitação quanto à posição de queda das sementes do mecanismo dosador com a roda de ponteiras. Já nas posições $A$ e $B$ não foi possível obter resultados favoráveis no desempenho da máquina. O coeficiente de variação também foi o mais baixo. Os índices de múltiplos e falhas obtidos nas outras posições avaliadas foram superiores, especialmente na posição B. 
Velocidade de $1,5 \mathrm{~m} \mathrm{~s}^{-1}$ (Mq3)

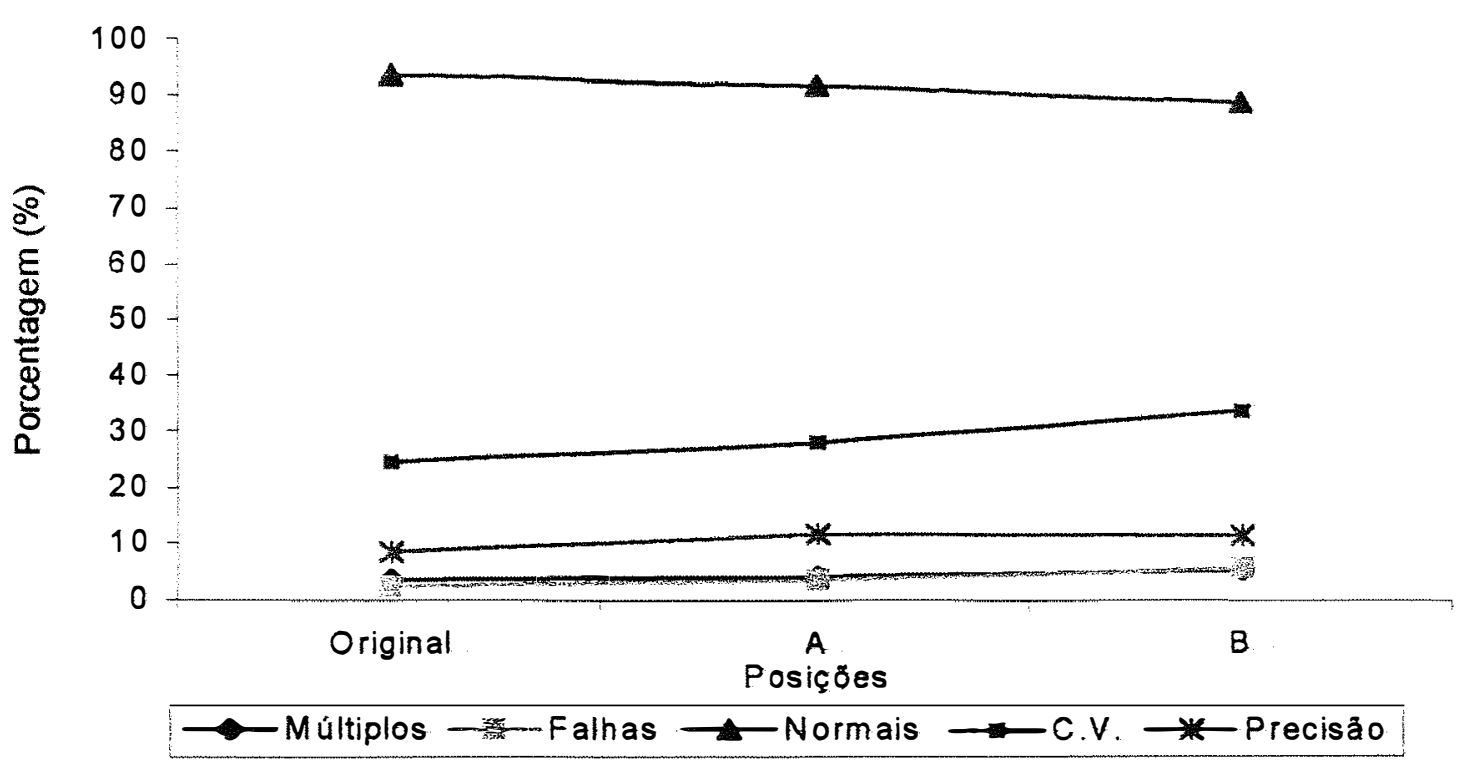

Figura 15 - Resultado do ensaio da regularidade de distribuição longitudinal de sementes em bancada de laboratório para a Mq3 para a velocidade de $1,5 \mathrm{~m} \mathrm{~s}^{-1}$.

$\mathrm{Na}$ Figura 16 são apresentados os resultados de ajuste para a velocidade de $2,0 \mathrm{~m} \mathrm{~s}^{-1}$, onde pode-se observar que a melhor sincronização obtida para o mecanismo dosador e as ponteiras foi a posição A. Nessa, foi obtida o maior índice de espaços normais, o menor coeficiente de variação e a melhor precisão em comparação com as demais posições. É possível observar também que os resultados obtidos nos índices de normais nas outras posições foram inferiores, como também as porcentagens de múltiplos e falha foram maiores. 


\section{Velocidade de $2,0 \mathrm{~m} \mathrm{~s}^{-1}$ (Mq3)}

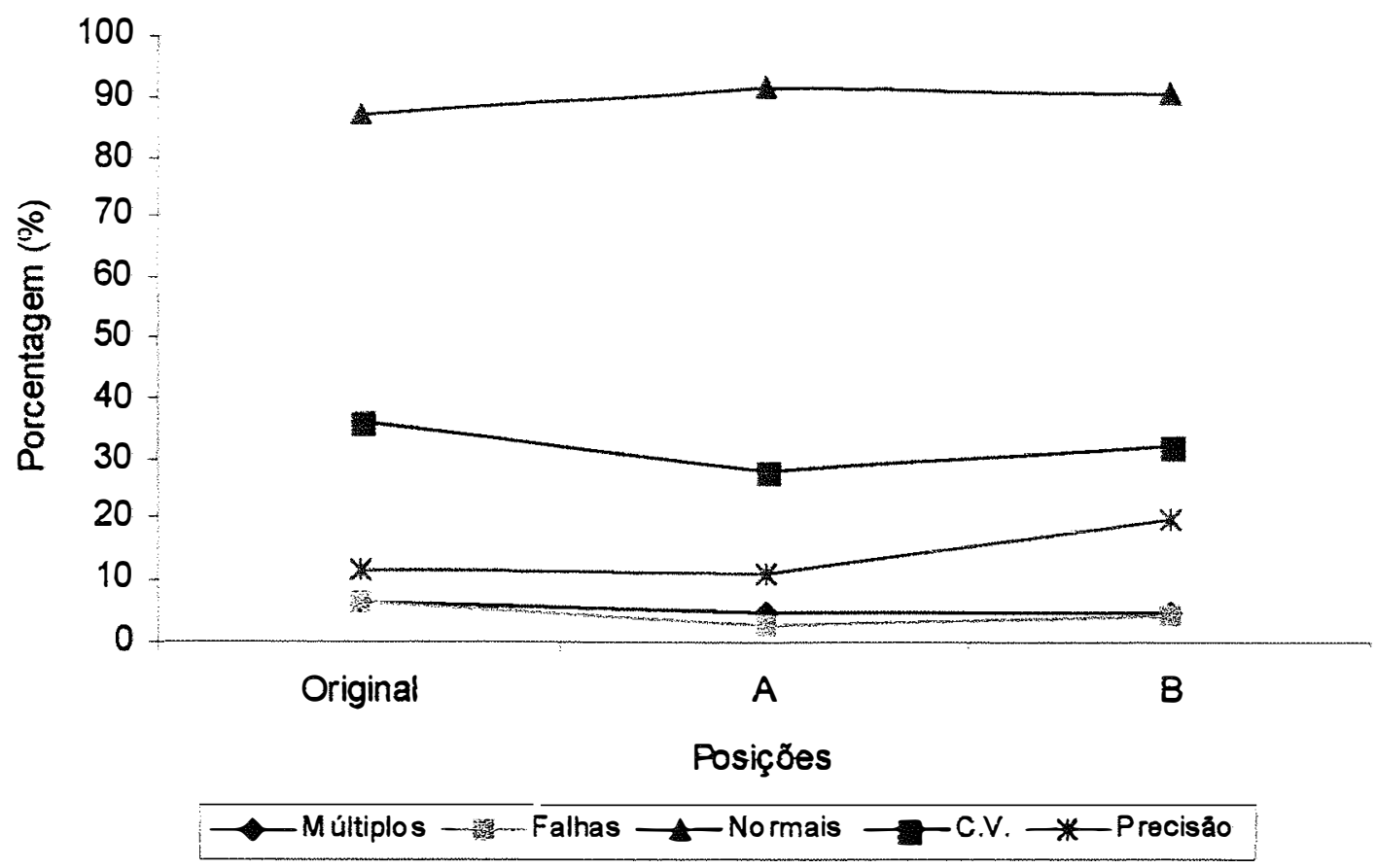

Figura 16 - Resultado do ensaio da regularidade de distribuição longitudinal de sementes em bancada de laboratório para a Mq3 para a velocidade de $2,0 \mathrm{~m} \mathrm{~s}^{-1}$.

$\mathrm{Na}$ Figura 17, apresenta-se os resultados de ajuste para a velocidade de $2,5 \mathrm{~m} \mathrm{~s}^{-1}$, onde pode-se observar que a melhor sincronização obtida para $\circ$ mecanismo dosador e as ponteiras foi na posição $A$, que revelou o maior índice de normais, o menor coeficiente de variação e a melhor precisão em comparação com as demais. A posição original foi a que apresentou os piores indices de normais, de múltiplos e de falhas . 
Velocidade de $2,5 \mathrm{~m} \mathrm{~s}^{-1}$ (Mq3)

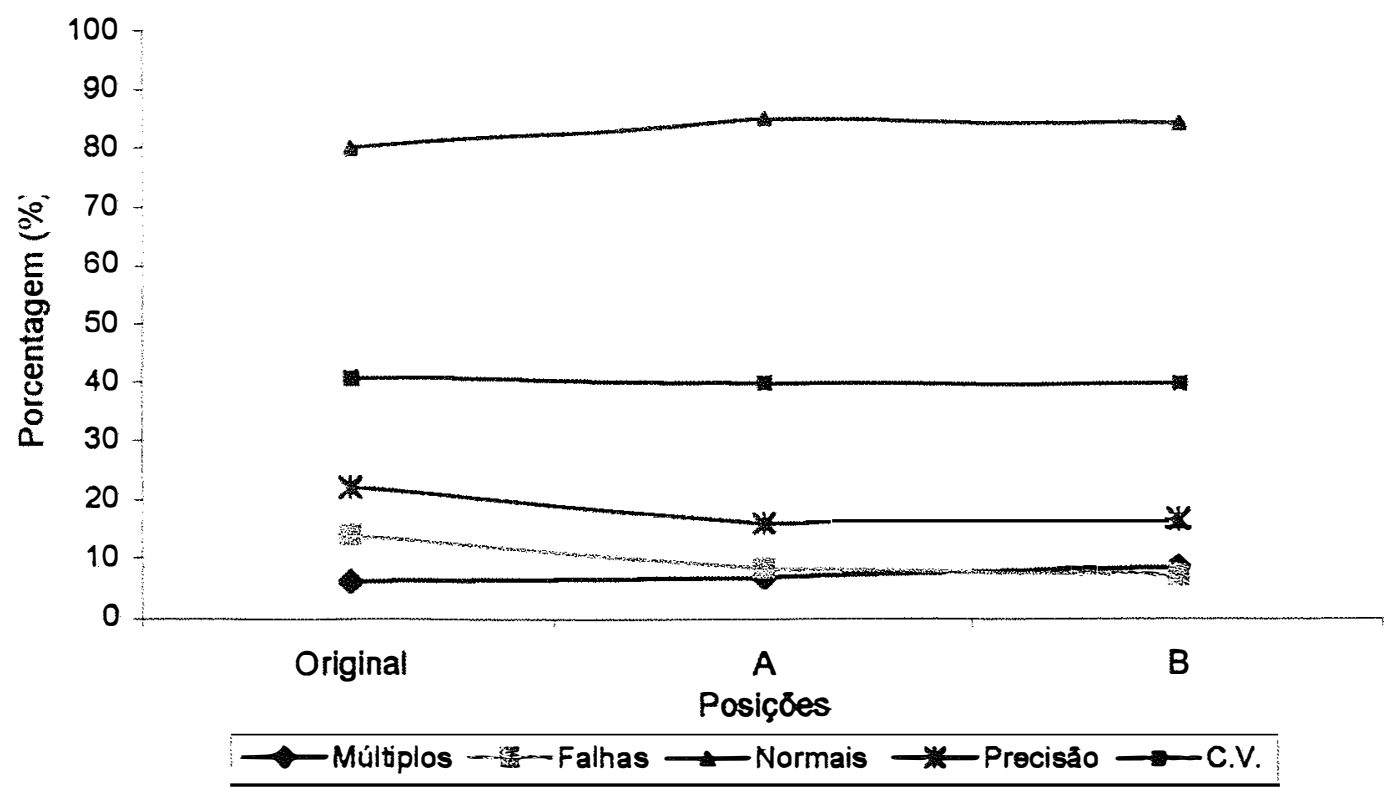

Figura 17 - Resultado do ensaio da regularidade de distribuição longitudinal de sementes em bancada de laboratório para a Mq3 para a velocidade de $2,5 \mathrm{~m} \mathrm{~s}^{-1}$.

A partir dos resultados obtidos nos ensaios de bancada foram estabelecidas as posições de ajuste de cada máquina.

Para a Mq1 adotou-se a posição 4 para a velocidade $1,5 \mathrm{~m} \mathrm{~s}^{-1}$, a posição 6 para a velocidade $2,0 \mathrm{~m} \mathrm{~s}^{-1}$ e posição 9 para a velocidade $2,5 \mathrm{~m} \mathrm{~s}^{-1}$. Já para a Mq2 adotou-se a posição $B$ para as três velocidades avaliadas. Por último, para a Mq3, foi adotada a posição original para a velocidade de $1,5 \mathrm{~m} \mathrm{~s}^{-}$ ${ }^{1}$ e a posição $A$ para as velocidade $2,0 \mathrm{~m} \mathrm{~s}^{-1}$ e $2,5 \mathrm{~m} \mathrm{~s}^{-1}$.

$\mathrm{Na}$ Tabela 4 são apresentados os resultados das comparações da regularidade de distribuição longitudinal das sementes, envolvendo espaçamentos normais, múltiplos, falhas, coeficiente de variação e precisão, de cada uma das posições de ajuste selecionadas para cada máquina, para as 
três velocidades de avanço simuladas em bancada durante os ensaios de laboratório. Também são apresentados os resultados da análise estatística.

Observa-se, na análise de variância, que não houve diferença significativa para os indices normais, o que indica que as máquinas não apresentaram diferença significativa de comportamentos dentro de cada velocidade de avanço.

Assim, pode-se verificar que a Mq1, apresentou os melhores indices de normais independente da velocidade, sendo que as Mq2 e Mq3 apresentaram os menores índices de normais e diferiram significativamente da Mq1. De forma geral, o indice de normais variou entre $95,4 \%$ e $96,4 \%$, obtendo-se seu melhor desempenho na velocidade de $2,0 \mathrm{~m} \mathrm{~s}^{-1}$.

Valores intermediários do indice de normais foram proporcionados pela Mq2, onde verificou-se que houve um aumento da porcentagem de normais, a medida em que se aumentava a velocidade de avanço. Aumentando-se a velocidade de $1,5 \mathrm{~m} \mathrm{~s}^{-1}$ para $2,0 \mathrm{~m} \mathrm{~s}^{-1}$, o indice de normais passou de $86,1 \%$ para $88,6 \%$ e quando a velocidade passou de $2,0 \mathrm{~m} \mathrm{~s}^{-1}$ para $2,5 \mathrm{~m} \mathrm{~s}^{-1}$, esse indice cresceu para $90 \%$

Com relação à $\mathrm{Mq3}$, pode-se observar que à medida que se aumentou a velocidade de avanço de $1,5 \mathrm{~m} \mathrm{~s}^{-1}$ para $2,5 \mathrm{~m} \mathrm{~s}^{-1}$, uma pequena diminuição das porcentagens do indice de normais refletiu em aumento do indice de múltiplos e de falhas na mesma proporção. Ao menos em parte isso deve-se à necessidade de um melhor ajuste entre posição de queda das sementes do mecanismo dosador e das ponteiras. Embora o fator sincronização tenha afetado o desempenho da máquina, 0 índice de normais chegou a valores de $93,9 \%$, registrado na velocidade de $1,5 \mathrm{~m} \mathrm{~s}^{-1}$.

Não houve diferenças significativas para os valores dos indices de múltiplos para as três máquinas e para as três velocidades de avanço. 
Tabela 4. Resultados dos ensaios da regularidade de distribuição longitudinal de sementes em Laboratório para as três máquinas ensaidas.

\begin{tabular}{|c|c|c|c|c|}
\hline \multicolumn{5}{|c|}{ Múltiplos (\%) } \\
\hline & & Velocidades & & \\
\hline Máquinas & $1,5 \mathrm{~m} \mathrm{~s}^{-1}$ & $2,0 \mathrm{~m} \mathrm{~s}^{-1}$ & $2,5 \mathrm{~m} \mathrm{~s}^{-1}$ & Média \\
\hline$M q 1$ & 2,8 & 2,2 & 1,8 & 2,3 \\
\hline Mq2 & 2,8 & 2,5 & 5,0 & 3,4 \\
\hline $\mathrm{Mq} 3$ & 3,5 & 4,9 & 5,0 & 4,4 \\
\hline $\operatorname{DMS}(0,05)=$ & 0,559 & & $\operatorname{Pr}>F(\%)=$ & 0,51824 \\
\hline \multicolumn{5}{|c|}{ Normais (\%) } \\
\hline \multicolumn{5}{|c|}{ Velocidades } \\
\hline Máquinas & $1,5 \mathrm{~m} \mathrm{~s}^{-1}$ & $2,0 \mathrm{~m} \mathrm{~s}^{-1}$ & $2,5 \mathrm{~m} \mathrm{~s}^{-1}$ & Média \\
\hline$M q 1$ & 96,1 & 96,4 & 95,4 & $96,0 \mathrm{a}$ \\
\hline Mq2 & 86,1 & 88,6 & 90,0 & $88,2 \mathrm{~b}$ \\
\hline $\mathrm{Mg} 3$ & 93,9 & 92,1 & 85,0 & $90,3 \mathrm{~b}$ \\
\hline DMS $(0,05)=$ & 3,103 & & $\mathrm{Pr}>\mathrm{F}(\%)=$ & 0,07269 \\
\hline \multicolumn{5}{|c|}{ Falhas (\%) } \\
\hline \multicolumn{5}{|c|}{ Velocidades } \\
\hline Máquinas & $1,5 \mathrm{~m} \mathrm{~s}^{-1}$ & $2,0 \mathrm{~m} \mathrm{~s}^{-1}$ & $2,5 \mathrm{~m} \mathrm{~s}^{-1}$ & Média \\
\hline$M q 1$ & $1,1 \quad a$ & $1,4 a$ & 2,8 & 1,8 \\
\hline Mq2 & $11, \uparrow b B$ & 8,9 b $A B$ & $5,0 \mathrm{~A}$ & 8,3 \\
\hline $\mathrm{Mg} 3$ & 2,5 a A & $2,9 a A B$ & $8,2 \mathrm{~B}$ & 4,5 \\
\hline $\operatorname{DMS}(0,05)=$ & 0,876 & & $\operatorname{Pr}>\mathrm{F}(\%)=$ & 0,00952 \\
\hline \multicolumn{5}{|c|}{ C.V. (\%) } \\
\hline \multicolumn{5}{|c|}{ Velocidades } \\
\hline Máquinas & $1,5 \mathrm{~m} \mathrm{~s}^{-1}$ & $2,0 \mathrm{~m} \mathrm{~s}^{-1}$ & $2,5 \mathrm{~m} \mathrm{~s}^{-1}$ & Média \\
\hline Mq1 & $19,6 \mathrm{a}$ & $48,1 \mathrm{a}$ & $20,8 a$ & 19,5 \\
\hline Mq2 & $37,5 \mathrm{~b}$ & $32,3 \mathrm{~b}$ & $30,4 a b$ & 33,4 \\
\hline $\mathrm{Mq} 3$ & 24,7 a A & $28,2 a b A B$ & $38,4 b \quad B$ & 30,4 \\
\hline $\operatorname{DMS}(0,05)=$ & 10,999 & & $\operatorname{Pr}>\mathrm{F}(\%)=$ & 0,04447 \\
\hline \multicolumn{5}{|c|}{ Precisāo (\%) } \\
\hline \multicolumn{5}{|c|}{ Velocidades } \\
\hline Máquinas & $1,5 \mathrm{~m} \mathrm{~s}^{-1}$ & $2,0 \mathrm{~m} \mathrm{~s}^{-1}$ & $2,5 \mathrm{~m} \mathrm{~s}^{-1}$ & Média \\
\hline$M q 1$ & $10,2 \mathrm{~b} \quad \mathrm{~B}$ & $7,1 a A$ & $7,3 a \mathrm{~A}$ & 8,2 \\
\hline $\mathrm{Mq} 2$ & 7,8 a A & $9,7 b \mathrm{AB}$ & 10,8 b B & 9,4 \\
\hline $\mathrm{Mq} 3$ & $8,6 a b A$ & 11,0 b B & 15,9 c C & 11,8 \\
\hline $\operatorname{DMS}(\overline{0,05})=$ & 1,950 & & $\operatorname{Pr}>\mathrm{F}(\%)=$ & 0,00952 \\
\hline
\end{tabular}

Médias seguidas por letras distintas, maiúsculas na linha e minúsculas na coluna diferem entre si pelo teste de Tukey a 0,05 de significância. 
No entanto verifica-se que crescendo a velocidade de $1,5 \mathrm{~m} \mathrm{~s}^{-1}$ para 2,5 $\mathrm{m} \mathrm{s}^{-1}$ ocorreu um acréscimo nas porcentagens de múltiplos. Esses índices variaram entre 2,8 \% e 5,0 \% para a Mq2 e entre 3,5 \% e 5,0 \% para a Mq3. Cabe ressaltar que esta máquina foi a que apresentou as porcentagens mais elevadas de múltiplos. O mesmo não aconteceu com a Mq1 quando a velocidade de avanço era aumentada, registrando diminuição do índice de múltiplos de $2,9 \%$ a $1,8 \%$.

Verificou-se pela análise de variância uma diferença significativa para os índices de falhas. Analisando primeiramente o efeito da velocidade em cada máquina, observou-se um decréscimo significativo para a Mq2 quando a velocidade de avanço era aumentada de $1,5 \mathrm{~m} \mathrm{~s}^{-1}$ para $2,5 \mathrm{~m} \mathrm{~s}^{-1}$. Já para a Mq3 foi observado um acréscimo nos índices de falhas. Na Mq1 não foi observado diferença entre as velocidades de avanço, embora os índices de falhas tenham aumentando.

Assim, quando comparado as máquinas, observou-se que nas velocidades de $1,5 \mathrm{~m} \mathrm{~s}^{-1}$ e $2,0 \mathrm{~m} \mathrm{~s}^{-1}$ as Mq1 e Mq3 obtiveram as menores porcentagens de falhas, apresentando diferença significativa com relação à Mq2. Já na velocidade de $2,5 \mathrm{~m} \mathrm{~s}^{-1}$ não ocorreram diferenças significativas entre as três máquinas e as porcentagens variaram de $2,8 \%$ a $8,2 \%$.

Também, verificou-se uma diferença significativa para os coeficientes de variação. Assim, analisando o efeito da velocidade dentro de cada máquina, somente a Mq3 registrou um aumento significativo do coeficiente de variação à medida que se aumentava a velocidade de avanço de $1,5 \mathrm{~m} \mathrm{~s}^{-1}$ para 2,5 $\mathrm{m} \mathrm{s}^{-1}$, passando de $24,7 \%$ para $38,4 \%$ o coeficientes de variação. A melhor porcentagem foi registrada na velocidade de $1,5 \mathrm{~m} \mathrm{~s}^{-1}$, embora não tenha diferido significativamente da porcentagem obtida na velocidade de $2,0 \mathrm{~m} \mathrm{~s}^{-1}$

Fazendo uma comparação entre as máquina é possivel observar que na velocidade de 1,5 $\mathrm{m} \mathrm{s}^{-1}$, as Mq1 e Mq3 apresentaram os menores valores de coeficiente de variação, diferindo significativamente da Mq2. Para a velocidade 
de 2,0 $\mathrm{m} \mathrm{s}^{-1}$, também, as menores médias foram obtidas pelas Mq1 e Mq3, apesar da Mq2 não ter diferido significativamente da Mq3. Na velocidade de 2,5 $\mathrm{m} \mathrm{s}^{-1}$ os menores coeficientes de variação foram registradas pelas Mq1 e Mq2, embora a Mq3 não tenha diferido da Mq2 estatisticamente.

A precisão (deposição das sementes em torno do ponto desejado) foi outro parâmetro no qual se verificou que houve interação estatisticamente significativa entre as velocidade de avanço e as máquinas.

Analisando o efeito da velocidade na precisão de cada máquina, verificou-se que para a Mq1 a melhor precisão foi observada na velocidades de $2,0 \mathrm{~m} \mathrm{~s}^{-1}$, que diferiu significativamente da velocidade mais baixa. No caso da Mq2, a maior precisão foi observada na velocidades de $1,5 \mathrm{~m} \mathrm{~s}^{-1}$, que diferiu significativamente da precisão registrada na velocidade de $2,5 \mathrm{~m} \mathrm{~s}^{-1}$. Para a $\mathrm{Mq3}$, a maior precisão foi obtida na velocidade de $1,5 \mathrm{~m} \mathrm{~s}^{-1}$, que diferiu das outras velocidades de avanço.

Quando comparando as máquinas entre si, observou-se que na velocidade de 1,5 $\mathrm{m} \mathrm{s}^{-1}$, as Mq2 e Mq3 apresentaram os melhores índices de precisão, com porcentagens de 7,8 \% e 8,6 \%, respectivamente. Embora a Mq3 não tenha diferido significativamente da Mq1. Já na velocidade de $2,0 \mathrm{~m} \mathrm{~s}^{-1}$ a Mq1 apresentou um índice de precisão de 7,1\% e diferiu estatisticamente das Mq2 e Mq3. Também na velocidade de $2,5 \mathrm{~m} \mathrm{~s}^{-1}$ a Mq1 registrou a melhor precisão e diferiu significativamente das demais.

De forma geral os menores coeficientes de variação, bem como os melhores índices de precisão obtidos durante os ensaios de laboratório estão diretamente relacionadas com as melhores porcentagens de espaçamentos considerados como normais.

A qualidade da semente, de acordo com o teste de germinação feitos no laboratório, como as porcentagens de danos mecânicos provocados pelas passagem das sementes pelos mecanismos dosadores das máquinas, são 
apresentada de acorde com as Regras para Análise de Sementes (Brasil, 1992).

$\mathrm{Na}$ Tabela 5 são apresentados os resultados da Mq1 (dosador pneumático). A análise de germinação feita no laboratório, não apresentou diferença significativa entre as médias dos tratamentos, incluindo as testemunhas sem e com talco. As porcentagens variaram entre $98,88 \%$ e $97,63 \%$.

Com relação á danificação de sementes que passaram pelo mecanismo dosador da Mq1, não foram observadas diferenças significativas entre as mesmas, No entanto, as porcentagens de danos obtidos nas duas últimas velocidades diferiram estatíticamente da testemunha sem talco.

Tabela 5. Resultado das médias dos tratamentos, referentes às porcentagens de germinação e danos físicos provocados às sementes pela Mq1.

\begin{tabular}{|c|c|c|c|}
\hline & Tratamentos & Danos (\%) & Germinação (\%) \\
\hline & Testemunha sem talco & $2,50 a$ & 98,88 \\
\hline & Testemunha com talco & $3,25 \mathrm{~b}$ & 97,88 \\
\hline & $1,5 \mathrm{~m} \mathrm{~s}^{-1}$ & $3,00 a b$ & 97,75 \\
\hline \multirow[t]{4}{*}{ Mq1 } & $2,0 \mathrm{~m} \mathrm{~s}^{-1}$ & $3,50 \mathrm{~b}$ & 98,63 \\
\hline & \multirow[t]{3}{*}{$2,5 \mathrm{~m} \mathrm{~s}^{-1}$} & $3,88 \mathrm{~b}$ & 97,63 \\
\hline & & $\operatorname{DMS}(0,05)=0.687$ & $\operatorname{DMS}(0,05)=0,373$ \\
\hline & & $P r>F(\%)=0,0072$ & $\operatorname{Pr}>F(\%)=0,2236$ \\
\hline
\end{tabular}

Médias seguidas por letras distintas na coluna diferem entre si pelo teste de Tukey a 0,05 de significância.

Por meio dos dados da Tabela 6 observa-se uma redução no poder germinativo para as sementes que passaram pelos mecanismos dosadores das 
Mq2 (dosador de dedos preensores) e Mq3 (dosador tipo colher). Só diferiram significativamente as porcentagens obtidas nas duas últimas velocidades da Mq3 e as médias estiveram entre $96,98 \%$ e $96,91 \%$.

Tabela 6. Resultado das médias dos tratamentos, referentes às porcentagens de germinação e danos físicos provocados às sementes.

\begin{tabular}{|c|c|c|c|}
\hline & Tratamentos & Danos (\%) & Germinação (\%) \\
\hline & Testemunha sem grafite & $2,50 a$ & 98,88 a \\
\hline & Testemunha com grafite & $2,95 a$ & 98,00 a \\
\hline & $1,5 \mathrm{~m} \mathrm{~s}^{-1}$ & $3,82 b$ & 97,96 a \\
\hline \multirow[t]{3}{*}{ Mq2 } & $2,0 \mathrm{~m} \mathrm{~s}^{-1}$ & $3,99 b$ & 97,89 a \\
\hline & $2,5 \mathrm{~m} \mathrm{~s}^{-1}$ & $4,18 b$ & $97,56 \mathrm{~b}$ \\
\hline & $1,5 \mathrm{~m} \mathrm{~s}^{-1}$ & $4,00 \mathrm{~b}$ & $97,75 a b$ \\
\hline \multirow[t]{4}{*}{ Mq3 } & $2,0 \mathrm{~m} \mathrm{~s}^{-1}$ & $4,25 b$ & $96,98 \mathrm{~b}$ \\
\hline & $2,5 \mathrm{~m} \mathrm{~s}^{-1}$ & $4,25 b$ & $96,91 \mathrm{~b}$ \\
\hline & & $\operatorname{DMS}(0,05)=1,031$ & $\operatorname{DMS}(0,05)=1,342$ \\
\hline & & $P_{r}>F(\%)=0,0007$ & $P_{r}>F(\%)=0,0083$ \\
\hline
\end{tabular}

Médias seguidas por letras distintas na coluna diferem entre si pelo teste de Tukey a 0,05 de significância.

$\mathrm{Na}$ mesma tabela, verifica-se também as porcentagens de danos mecânicos das sementes que passaram pelos mecanismos dosadores das Mq2 e Mq3, onde não foram observadas diferenças significativas entres as duas. As porcentagens de danificação variaram entre $3,82 \%$ a $4,15 \%$ e diferiram significativamente com as duas testemunhas. 


\subsection{Ensaios de campo}

Os ensaios de campo foram realizados em três regiões distintas no Estado de São Paulo. Todas as áreas experimentais apresentavam cobertura de palhada para semeadura direta. Os resultados são apresentados para cada área separadamente.

\subsection{1 Área experimental de Piracicaba}

A avaliação do percentual do índice de cobertura do solo com palhada como também a quantidade de matéria seca, para a área experimental de Piracicaba, SP, prévio à implantação da semeadura, são apresentados na Tabela 7.

Observa-se que as porcentagens de cobertura do solo registradas encontraram-se entre $89 \%$ e $95 \%$, podendo ser considerada como uma área de cobertura uniforme, com média de $91,25 \%$ e coeficiente de variação de $2,25 \%$.

A quantidade de matéria seca presente no solo nas amostras coletadas antes do início das operações de semeadura, variou entre 2,66 tha ${ }^{-1}$ e 10,28 t $\mathrm{ha}^{-1}$, ficando com uma média de $5,85 \mathrm{t} \mathrm{ha}^{-1}$ e com um coeficiente de variação de $40,15 \%$. Esses não refletem os resultados obtidos nas porcentagens de cobertura, apresentando deposição irregular de material sobre a superfície. 
Tabela 7. Resultado do índice de cobertura e matéria seca sobre o solo prévio à semeadura na área experimental de Piracicaba, SP.

\begin{tabular}{|c|c|c|}
\hline \multicolumn{3}{|c|}{ Área Experimental de Piracicaba, SP } \\
\hline Numero da & Matéria Seca & Indice de Cobertura \\
\hline Amostra & $\left(t h a^{-1}\right)$ & $(\%)$ \\
\hline 1 & 10,28 & 90 \\
\hline 2 & 5,70 & 89 \\
\hline 3 & 5,37 & 92 \\
\hline 4 & 2,66 & 90 \\
\hline 5 & 9,51 & 90 \\
\hline 6 & 3,74 & 94 \\
\hline 7 & 8,13 & 95 \\
\hline 8 & 4,91 & 93 \\
\hline 9 & 6,03 & 93 \\
\hline 10 & 5,84 & 90 \\
\hline 11 & 3,93 & 90 \\
\hline 12 & 4,12 & 89 \\
\hline Média & 5,85 & 91,25 \\
\hline Desvio Padrão & 2,35 & 2,05 \\
\hline Coeficiente de Variação & 40,15 & 2,25 \\
\hline
\end{tabular}

Os valores médios de densidade do solo e da umidade, coletados previamente à semeadura, nas profundidades de 0 a 0,05 m e de 0,05-0,10 m, são apresentados na Tabela 8 . Observa-se pequeno incremento, tanto na densidade do solo quanto na sua umidade, entre a superfície e a camada mais profunda. Essa diferença de heterogeneidade reflete a variação natural do solo ao longo do perfil. 
Tabela 8. Resultados médios e coeficiente de variação da densidade do solo e da umidade nas duas profundidades analisadas, no período que antecedeu à semeadura, para a área de Piracicaba, SP.

\section{Área Experimental de Piracicaba, SP}

\begin{tabular}{ccccc}
\hline $\begin{array}{c}\text { Profundidade } \\
(\mathrm{m})\end{array}$ & $\begin{array}{c}\text { Densidade do solo } \\
\left(\mathrm{g} \mathrm{cm}^{-3}\right)\end{array}$ & $\begin{array}{c}\text { C.V. } \\
(\%)\end{array}$ & $\begin{array}{c}\text { Umidade } \\
(\%)\end{array}$ & $\begin{array}{c}\text { C.V. } \\
(\%)\end{array}$ \\
\hline 0 a 0,05 & 1,25 & 10,23 & 10,86 & 24,49 \\
0,05 a 0,10 & 1,28 & 6,53 & 12,09 & 28,15 \\
\hline
\end{tabular}

Nos aspectos referentes à compactação do solo, os resultados do índice de cone indicam níveis de compactação mais elevados entre as camadas de 0,35 m a 0,55 m, como pode-se observar no gráfico da resistência a penetração do solo (Figura 18). Considerando-se que a semeadura foi realizada na profundidade de 0,05 $\mathrm{m}$ aproximadamente, os níveis de compactação nas camadas mais profundas não deve ter afetado a germinação das sementes. 
Resistência à Penetração do solo (kPa)

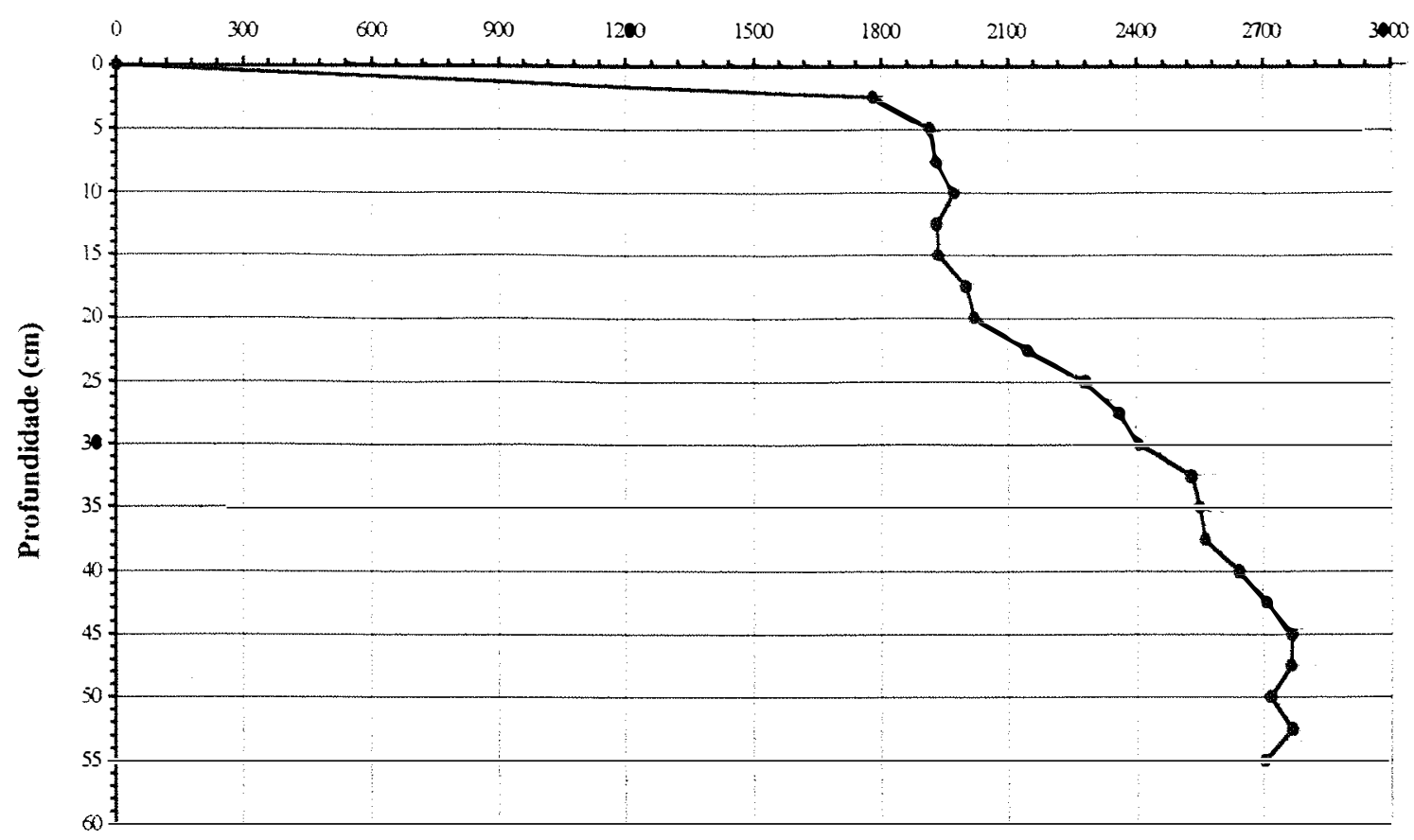

Figura 18 - Níveis de compactação do solo da área experimental de Piracicaba, SP, expressos pelo índice de cone; média das 36 amostras obtida com penetrógrafo.

Os resultados dos espaçamentos entre plantas para a área experimental de Piracicaba estão apresentados na Tabela 9, juntamente com os resultados da análise de variância dos dados.

$\mathrm{Na}$ análise dos dados verifica-se que não houve diferença significativa para a interação máquinas/velocidades, nos diferentes parâmetros utilizados para avaliar a qualidade da distribuição de freqüência dos espaçamentos entre plantas, a exceção do coeficiente de variação que foi a única variável que registrou diferença significativa. 
Tabela 9. Resultados do ensaio da regularidade de distribuição longitudinal de plantas da área experimental de Piracicaba, SP.

\begin{tabular}{|c|c|c|c|c|}
\hline \multicolumn{5}{|c|}{ Múltiplos (\%) } \\
\hline & & Velocidade & & \\
\hline Máquinas & $1,5 \mathrm{~m} \mathrm{~s}^{-1}$ & $2,0 \mathrm{~m} \mathrm{~s}^{-1}$ & $2,5 \mathrm{~m} \mathrm{~s}^{-1}$ & Média \\
\hline$M q 1$ & 3,6 & 4,2 & 7,2 & $5,0 \mathrm{~b}$ \\
\hline Mq2 & 1,4 & 1,8 & 1,8 & $1,7 \mathrm{a}$ \\
\hline Mq3 & 2,9 & 4,6 & 8,6 & $5,4 \mathrm{~b}$ \\
\hline $\operatorname{DMS}(0,05)=$ & 0,354 & & $\operatorname{Pr}>\mathrm{F}(\%)=$ & 0,13223 \\
\hline \multicolumn{5}{|c|}{ Normais (\%) } \\
\hline \multicolumn{5}{|c|}{ Velocidades } \\
\hline Máquinas & $1,5 \mathrm{~m} \mathrm{~s}^{-1}$ & $2,0 \mathrm{~m} \mathrm{~s}^{-1}$ & $2,5 \mathrm{~m} \mathrm{~s}^{-1}$ & Média \\
\hline Mq1 & 67,1 & 69,8 & 59,6 & $65,5 a$ \\
\hline Mq2 & 62,5 & 67,1 & 58,9 & $62,8 \mathrm{~b}$ \\
\hline $\mathrm{Mg} 3$ & 64,3 & 60,0 & 55,7 & $60,0 \mathrm{~b}$ \\
\hline $\operatorname{DMS}(0,05)=$ & 3,992 & & $\operatorname{Pr}>\mathrm{F}(\%)=$ & 0,11455 \\
\hline \multicolumn{5}{|c|}{ Falhas (\%) } \\
\hline \multicolumn{5}{|c|}{ Vetocidades } \\
\hline Máquina & $1,5 \mathrm{~m} \mathrm{~s}^{-1}$ & $2,0 \mathrm{~m} \mathrm{~s}^{-1}$ & $2,5 \mathrm{~m} \mathrm{~s}^{-1}$ & Média \\
\hline Mq1 & 29,3 & 26,0 & 33,2 & $29,5 a$ \\
\hline Mq2 & 36,1 & 31,1 & 39,3 & $35,5 \mathrm{~b}$ \\
\hline $\mathrm{Mq} 3$ & 32,9 & 35,4 & 35,7 & $34,7 \mathrm{~b}$ \\
\hline DMS $(0,05)=$ & 0,428 & & $\operatorname{Pr}>F(\%)=$ & 0,05918 \\
\hline \multicolumn{5}{|c|}{ C.V. (\%) } \\
\hline \multicolumn{5}{|c|}{ Vetocidade } \\
\hline Máquinas & $1,5 \mathrm{~m} \mathrm{~s}^{-1}$ & $2,0 \mathrm{~m} \mathrm{~s}^{-1}$ & $2,5 \mathrm{~m} \mathrm{~s}^{-1}$ & Média \\
\hline$M q 1$ & $52,4 \quad A B$ & 42,2 a $A$ & 60,5 a $B$ & 53,3 \\
\hline Mq2 & $59,4 \quad B$ & 47,2 ab $A$ & $63,3 \mathrm{~b} B$ & 55,1 \\
\hline $\mathrm{Mq} 3$ & 56,8 & 53,0 b & $64,1 \mathrm{~b}$ & 58,0 \\
\hline DMS $(0,05)=$ & 11,369 & & $\operatorname{Pr}>\mathrm{F}(\%)$ & 0,00032 \\
\hline \multicolumn{5}{|c|}{ Precisão (\%) } \\
\hline \multicolumn{5}{|c|}{ Vetocidades } \\
\hline Máquinas & $1,5 \mathrm{~m} \mathrm{~s}^{-1}$ & $2,0 \mathrm{~m} \mathrm{~s}^{-1}$ & $2,5 \mathrm{~m} \mathrm{~s}^{-1}$ & Média \\
\hline$M q \uparrow$ & 13,2 & 14,8 & 16,3 & $14,8 a$ \\
\hline Mq2 & 18,0 & 17,3 & 17,8 & $17,7 b$ \\
\hline $\mathrm{Mq3}$ & 14,5 & 15,6 & 19,4 & $16,5 a b$ \\
\hline $\operatorname{DMS}(0,05)=$ & 2,596 & & $\operatorname{Pr}>F(\%)=$ & 0,16971 \\
\hline
\end{tabular}

Médias seguidas por letras distintas, maiúsculas na linha e minúsculas na coluna diferem entre si pelo teste de Tukey a 0,05 de significância. 
Os resultados mostraram que a máquina com melhor desempenho foi a Mq1, a qual difere significativamente das outras máquinas, independente das três velocidades ensaiadas. O melhor índice de normais foi $69,8 \%$, observado na velocidade de $2,0 \mathrm{~m} \mathrm{~s}^{-1}$.

Pode-se observar de forma geral, em todas as máquinas, um decréscimo, embora não seja significativo, nas porcentagens de normais, à medida que se aumentava a velocidade de $2,0 \mathrm{~m} \mathrm{~s}^{-1}$ para $2,5 \mathrm{~m} \mathrm{~s}^{-1}$.

Verificou-se também, que independentemente das velocidades ensaiadas, os menores índices múltiplos foram obtidas pela Mq2, com porcentagens que variaram de $1,4 \%$ a $1,8 \%$. Assim também é possível observar que a Mq1, apresentou as menores porcentagens de falhas, as quais variaram entre $26,0 \%$ e $33,2 \%$.

Como mencionado acima, a análise de variância mostrou diferença significativa só nos coeficientes de variação, quando analisado o efeito da velocidade dentro de cada máquina. É possivel observar que no caso da Mq1 a menor porcentagem foi obtida na velocidade de $2,0 \mathrm{~m} \mathrm{~s}^{-1}$, com um coeficiente de $42,2 \%$, o qual diferiu significativamente da obtida na velocidade de $2,5 \mathrm{~m}$ $\mathrm{s}^{-1}$. Para a Mq2, o melhor coeficiente de variação, também obtido na velocidade de $2,0 \mathrm{~m} \mathrm{~s}^{-1}$, mais diferiu significativamente das velocidades de $1,5 \mathrm{~m} \mathrm{~s}^{-1}$ e 2,5 $\mathrm{m} \mathrm{s}^{-1}$, com um coeficiente de 47,2\%. Na Mq3 não foram observadas diferenças significativas entre as velocidades e as mesmas variaram entre $53 \%$ e $64,1 \%$.

Ao comparar as máquinas entre si, é possível observar que quando a velocidades foi de $2,0 \mathrm{~m} \mathrm{~s}^{-1}$ a Mq1 apresentou o menor coeficiente de variação, diferindo significativamente da Mq3. Já na velocidade de $2,5 \mathrm{~m} \mathrm{~s}^{-1}$ o menor coeficiente de variação foi da Mq1 que diferiu significativamente das Mq2 e Mq3.

A precisão não registrou diferença significativa para interação máquina e velocidade. Para esta variável analisada, as Mq1 e Mq3 apresentaram as 
melhores médias de precisão, com porcentagens na ordem de $13,2 \%$ e 14,5 $\%$, respetivamente, apesar da Mq2 não ter diferido significativamente da Mq3.

\subsection{1 Área experimental de Campos Novos Paulista}

A avaliação do percentual do índice de cobertura do solo com palhada como também a quantidade de matéria seca, para a área experimental de Campos Novos Paulista, SP, prévio à implantação da semeadura, são apresentados na Tabela 10.

Os indices de cobertura apresentaram porcentagens entre $55 \%$ e 65 $\%$, com uma média de 60,25 \% e com um coeficiente de variação de 4,70 \%. A uniformidade da distribuição da palha sobre o terreno pode ser considerada como aceitável.

As amostras de matéria seca coletada variaram na ordem de $2,55 \mathrm{t} \mathrm{ha}^{-1}$ a $8,74 \mathrm{tha}^{-1}$, dando um volume médio de palha sobre o terreno de 4,84 $\mathrm{t} \mathrm{ha}^{-1}$, com um coeficiente de variação de 41,31 \%, indicando uma deposição irregular de material sobre o solo. 
Tabela 10. Resultado do índice de cobertura e matéria seca sobre o solo prévio à semeadura na área experimental de Campos Novos Paulista, SP.

\begin{tabular}{|c|c|c|}
\hline \multicolumn{3}{|c|}{ Área Experimental de Campos Novos Paulista, SP } \\
\hline Numero da & Matéria seca & Índice de cobertura \\
\hline Amostra & $\left(t h a^{-1}\right)$ & $(\%)$ \\
\hline 1 & 6,80 & 62 \\
\hline 2 & 3,39 & 60 \\
\hline 3 & 2,55 & 55 \\
\hline 4 & 5,63 & 57 \\
\hline 5 & 2,59 & 60 \\
\hline 6 & 3,04 & 62 \\
\hline 7 & 4,92 & 63 \\
\hline 8 & 7,42 & 58 \\
\hline 9 & 8,74 & 65 \\
\hline 10 & 4,09 & 62 \\
\hline 11 & 3,70 & 61 \\
\hline 12 & 5,21 & 58 \\
\hline Média & 4,84 & 60,25 \\
\hline Desvio Padrão & 2,00 & 2,83 \\
\hline Coeficiente de variação & 41,31 & 4,70 \\
\hline
\end{tabular}

Os valores médios de densidade do solo e de umidade, coletados previamente às operações de semeadura, nas profundidades de 0 a $0,05 \mathrm{~m} \mathrm{e}$ de 0,05 m a 0,10 m, são apresentados na Tabela 11. Observa-se que não houve variação na densidade do solo nas camadas analisadas. Já o teor de água no solo registrou um pequeno aumento na profundidade de 0,05 $\mathrm{m}$ a 0,10 m. 
Tabela 11. Resultados médios da densidade do solo e da umidade nas diferentes profundidades analisadas, no período que antecedeu a semeadura, na área experimental de Campos Novos Paulista, SP.

\begin{tabular}{|c|c|c|c|c|}
\hline \multicolumn{5}{|c|}{ Área Experimental de Campos Novos Paulista, SP } \\
\hline $\begin{array}{l}\text { Profundidade } \\
\text { (m) }\end{array}$ & $\begin{array}{c}\text { Densidade do solo } \\
\left(\mathrm{g} . \mathrm{cm}^{-3}\right)\end{array}$ & $\begin{array}{l}\text { C.V. } \\
(\%)\end{array}$ & Umidade (\%) & $\begin{array}{l}\text { C.V. } \\
(\%)\end{array}$ \\
\hline 0 a 0,05 & 1,11 & 13,18 & 23,72 & 26,96 \\
\hline 0,05 a 0,10 & 1,10 & 6,12 & 27,87 & 27,86 \\
\hline
\end{tabular}

Com relação à compactação do solo, os resultados do índice de cone indicam niveis de compactação mais elevados entre as camadas de 0,35 m a 0,40 m, como pode-se observar no gráfico da resistência a penetração do solo (Figura 19). Considerando que a profundidade de semeadura foi realizada a 0,05 m aproximadamente, os níveis de compactação nas camadas mais profundas não deve ter afetado a germinação das sementes. 


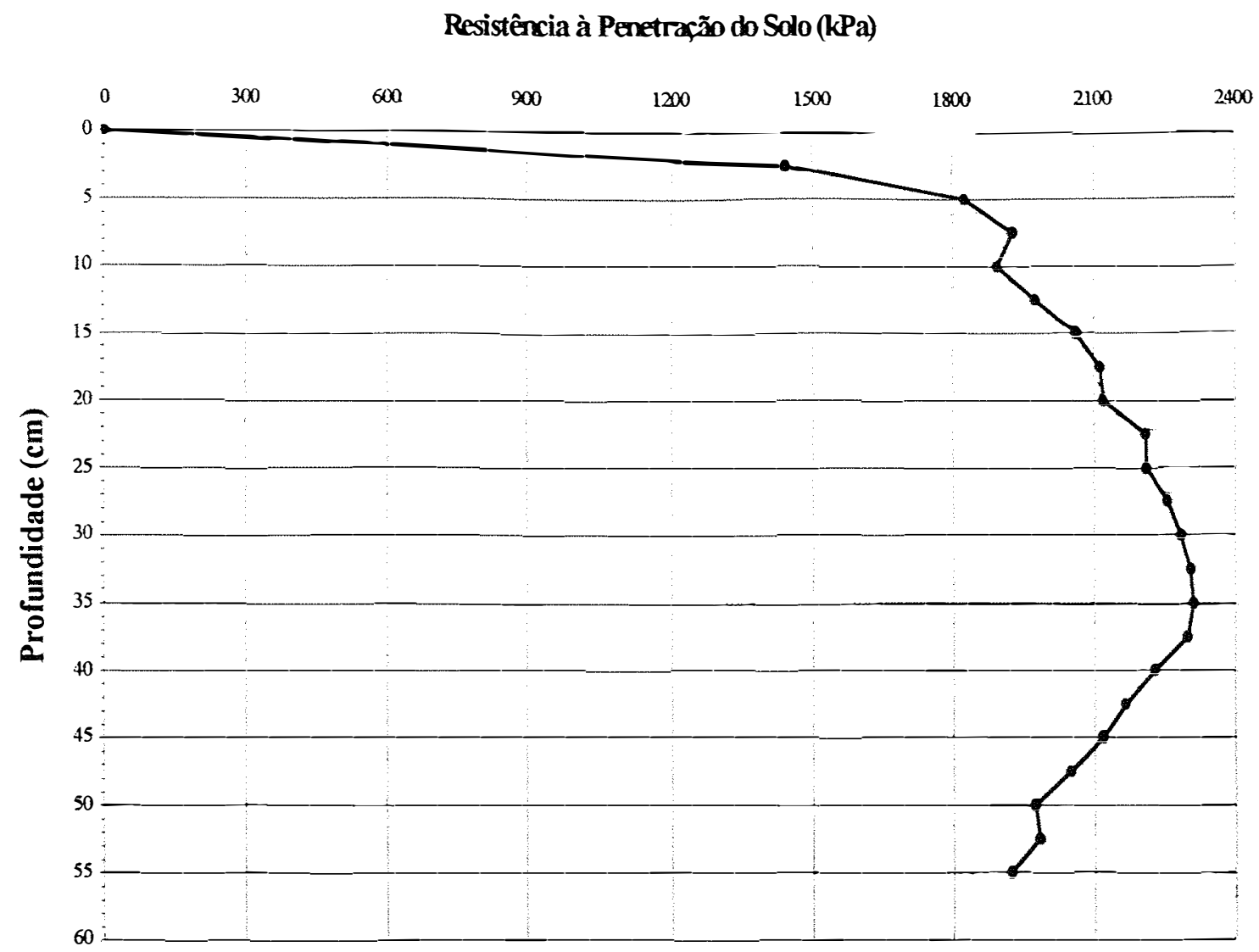

Figura 19 - Níveis de compactação do solo da área experimental de Campos Novos Paulista, SP expresso pelo do índice de cone; média das 36 amostras obtida com penetrógrafo.

$\mathrm{Na}$ Tabela 12 estão apresentados os resultados dos ensaios de campo da área experimental de Campos Novos Paulista, SP, como assim também a síntese da análise de variância dos parâmetros utilizados para avaliar a uniformidade de distribuição de plantas.

A regularidade de distribuição longitudinal de plantas na fileira teve um comportamento diferenciado entre tratamentos, conforme resultados obtidos na análise fatorial, para os índices considerados como normais. 
Tabela 12. Resultados dos ensaios da regularidade de distribuição longitudinal de plantas da área experimental de Campos Novos Paulista, SP.

\begin{tabular}{|c|c|c|c|c|}
\hline \multicolumn{5}{|c|}{ Múltiplos (\%) } \\
\hline \multirow[b]{2}{*}{ Máqui nas ${ }^{1}$} & \multicolumn{3}{|c|}{ Veloci dades } & \multirow[b]{2}{*}{ Média } \\
\hline & $1,5 \mathrm{~m} \mathrm{~s}^{-1}$ & $2,0 \mathrm{~m} \mathrm{~s}^{-1}$ & $2,5 \mathrm{~m} \mathrm{~s}^{-1}$ & \\
\hline$M q 1$ & 6,1 & 1,4 & 6,8 & $4,8 \mathrm{~b}$ \\
\hline Mq2 & 1,8 & 0,7 & 2,9 & $1,8 \mathrm{a}$ \\
\hline Mq3 & 3,6 & 3,9 & 5,7 & $4,4 b$ \\
\hline $\operatorname{DMS}(0,05)=$ & 0,347 & & $\mathrm{Pr}>\mathrm{F}(\%)=$ & 0.16309 \\
\hline \multicolumn{5}{|c|}{ Normais (\%) } \\
\hline \multicolumn{5}{|c|}{ Veloci dades } \\
\hline Máqui nas' & $1,5 \mathrm{~m} \mathrm{~s}^{-1}$ & $2.0 \mathrm{~m} \mathrm{~s}^{-1}$ & $2.5 \mathrm{~m} \mathrm{~s}^{-1}$ & Médi a \\
\hline$M q 1$ & $77,5 \mathrm{ab} B$ & 86,8 a $A$ & $71,8 \quad B$ & 78,7 \\
\hline Mq2 & $73,6 b$ & $73,9 b$ & 69,3 & 72,3 \\
\hline Mq3 & 81,8 a $A$ & 78,9 b A & $64,6 \mathrm{~B}$ & 75,1 \\
\hline DMS $(0,05)=$ & 5,479 & & $\operatorname{Pr} \cdot F(\%)=$ & 0,01001 \\
\hline \multicolumn{5}{|c|}{ Falhas (\%) } \\
\hline \multicolumn{5}{|c|}{ Veloci dades } \\
\hline Máqui nas & $1,5 \mathrm{~m} \mathrm{~s}^{-1}$ & $2,0 \mathrm{~m} \mathrm{~s}^{-1}$ & $2,5 \mathrm{~m} \mathrm{~s}^{-1}$ & Médi a \\
\hline$M q 1$ & 16,4 a $A B$ & 11,7 a $A$ & $21,4 \quad B$ & 16,5 \\
\hline Mq2 & $24,6 \mathrm{~b}$ & $25,4 \mathrm{~b}$ & 27,9 & 26,0 \\
\hline Mq3 & 14,3 a $A$ & 17,5 a $A$ & 29,6 B & 20,5 \\
\hline $\operatorname{DMS}(0,05)=$ & 0,674 & & $\operatorname{Pr}>\mathrm{F}(\%)=$ & 0,02290 \\
\hline \multicolumn{5}{|c|}{ C.V. $(\%)$} \\
\hline \multicolumn{5}{|c|}{ Veloci dades } \\
\hline Máqui nas ${ }^{1}$ & $1,5 \mathrm{~m} \mathrm{~s}^{-1}$ & $2,0 \mathrm{~m} \mathrm{~s}^{-1}$ & $2,5 \mathrm{~m} \mathrm{~s}^{-1}$ & Médi a \\
\hline$M q 1$ & 49,2 & 37,8 & 52,3 & $46,4 a$ \\
\hline Mq2 & 51,6 & 50,3 & 62,7 & $54,9 a b$ \\
\hline $\mathrm{Mq3}$ & 43,4 & 51,9 & 71,3 & $55,5 b$ \\
\hline $\operatorname{DMS}(0,05)=$ & 8,557 & & $\operatorname{Pr}>F(\%)=$ & 0,10747 \\
\hline \multicolumn{5}{|c|}{ Precisão (\%) } \\
\hline \multicolumn{5}{|c|}{ Veloci dades } \\
\hline Máqui nas ${ }^{1}$ & $1,5 \mathrm{~m} \mathrm{~s}^{-1}$ & $2,0 \mathrm{~m} \mathrm{~s}^{-1}$ & $2,5 \mathrm{~m} \mathrm{~s}^{-1}$ & Médi a \\
\hline$M q 1$ & 15,2 & 11,6 & 14,6 & 13,8 \\
\hline Mq2 & 13,9 & 14,2 & 14,8 & 14,3 \\
\hline Mq3 & 14,9 & 15,1 & 16,4 & 15,5 \\
\hline $\operatorname{DMS}(0,05)=$ & 2,907 & & $\mathrm{Pr}>\mathrm{F}(\%)=$ & 0,67427 \\
\hline
\end{tabular}

Médias seguidas por letras distintas, maiúsculas na linha e minúsculas na coluna, diferem entre si pelo teste de Tukey a 0,05 de significância 
Avaliando primeiramente o efeito da velocidade nos índices de normais para cada máquina, observa-se que na Mq1, a maior porcentagem de espaços normais foi obtida na velocidade de $2,0 \mathrm{~m} \mathrm{~s}^{-1}$, com porcentagem de $86,8 \%$, que diferiu significativamente das demais. Para a Mq2 não foi observada diferença significativa entre as velocidades. As porcentagens estiveram entre $73,9 \% \mathrm{e}$ 69,3 \%. Já, para a Mq3, o fator velocidade influenciou significativamente nas porcentagens de normais, verificando-se uma diminuição de $81,8 \%$ para 64,6 $\%$, quando a velocidade passou de $1,5 \mathrm{~m} \mathrm{~s}^{-1}$ para $2,5 \mathrm{~m} \mathrm{~s}^{-1}$.

Ao comparar o desempenho das máquinas entre si, pode-se observar que as Mq1 e Mq3, na velocidade de trabalho de 1,5 $\mathrm{m} \mathrm{s}^{-1}$, apresentaram as melhores porcentagens de normais, apesar da Mq2 não ter diferido significativamente da Mq1. Na velocidade de 2,0 $\mathrm{m} \mathrm{s}^{-1}$, o melhor desempenho foi obtido pela Mq1, que diferiu significativamente das demais. Nenhuma diferença significativa foi observada entre as máquinas para a velocidade de $2,5 \mathrm{~m} \mathrm{~s}^{-1}$.

Para os índices de múltiplos, é possivel observar que a interação máquinas e velocidades foi não significativa. Verificando-se que quando comparou-se o desempenho das máquinas, o menor índice de múltiplos foi obtido pela Mq2, independente das velocidades. A mesma diferiu significativamente das Mq1 e Mq3.

A análise estatística mostrou ter uma diferença significativa para as porcentagens de falha. Analisado o efeito da velocidade em cada máquina, é possivel observar que na Mq1, a menor porcentagem de falha foi observada na velocidade de $2,0 \mathrm{~m} \mathrm{~s}^{-1}$, com uma porcentagem de $11,7 \%$, que diferiu significativamente da velocidade mais alta. Já para a Mq2, não foi observada diferença entre as velocidades ensaiadas. Os índices de falhas variaram entre $24,6 \%$ a $27,9 \%$. No caso da Mq3, observou-se um aumento significativo da porcentagem de falha, passando de $14,3 \%$ para $29,6 \%$, à medida em que a velocidade passou de $1,5 \mathrm{~m} \mathrm{~s}^{-1}$ para $2,5 \mathrm{~m} \mathrm{~s}^{-1}$. 
Fazendo uma comparação entre as máquinas, pode-se observar que nas velocidades de trabalho de $1,5 \mathrm{~m} \mathrm{~s}^{-1}$ e 2,0 $\mathrm{m} \mathrm{s}^{-1}$ as Mq1 e Mq3 registaram as menores porcentagens de falhas e diferiram significativamente em relação à Mq2. Já para a velocidade de $2,5 \mathrm{~m} \mathrm{~s}^{-1}$ não aconteceu diferença significativa entre máquinas.

Nenhuma diferença significativa foi observada nos coeficientes de variação para interação máquina e velocidade. Independentemente das velocidades, verificou-se que os menores coeficientes foram obtidos pelas Mq1 e Mq2, com valores de 46,4\% e 54,9\% respetivamente, embora a Mq3 não ter diferido significativamente da Mq2.

Também não foram registradas diferenças significativas para os índices de precisão em nenhuma das máquinas. Em geral, a precisão diminuiu com o acréscimo da velocidade de trabalho e os niveis de precisão variaram entre $11,6 \%$ e 16,4 \%. No caso da Mq1, o melhor índice precisão foi observado na velocidade de $2,0 \mathrm{~m} \mathrm{~s}^{-1}$, ao contrário das Mq2 e Mq3, onde os melhores índices de precisão foram obtidos na velocidade $1,5 \mathrm{~m} \mathrm{~s}^{-1}$.

\subsection{3. Área Experimental de Pirassununga}

A avaliação do percentual do índice de cobertura do solo com palhada como também a quantidade de matéria seca, para a área experimental de Pirassununga, SP, prévio à implantação da semeadura, são apresentados na Tabela 13. 
Os indices de cobertura encontravam-se entre $40 \%$ e $49 \%$, com 44,08 \% em média e com um coeficiente de variação de 7,46 \%. Embora os valores obtidos também tem sido baixos, ainda estão dentro dos limites estipulados por Coelho (1997) e Derpsch (1997), onde valores acima de 30 \% são considerados como conservacionista.

Tabela 13. Resultado do índice de cobertura e matéria seca sobre o solo prévio à semeadura na área experimental de Pirassununga, SP.

\begin{tabular}{ccc}
\hline \multicolumn{3}{c}{ Área Experimental de Pirassununga, SP } \\
\hline Numero da & Matéria seca & Índice de cobertura \\
Amostra & $\left(\mathrm{t} \mathrm{ha}^{-1}\right)$ & $(\%)$ \\
\hline 1 & 2,53 & 43 \\
2 & 2,74 & 47 \\
3 & 2,06 & 49 \\
4 & 2,44 & 42 \\
5 & 1,86 & 41 \\
6 & 2,23 & 40 \\
7 & 2,51 & 40 \\
8 & 2,92 & 42 \\
9 & 2,55 & 47 \\
10 & 2,14 & 44 \\
11 & 2,88 & 45 \\
12 & 2,20 & 49 \\
\hline Média & 2,42 & 44,08 \\
Desvio Padrão & 0,33 & 3,29 \\
Coeficiente de variação & 13,60 & 7,46 \\
\hline
\end{tabular}

O volume de matéria seca coletado na área esteve entre $1,86 \mathrm{t} \mathrm{ha}^{-1} \mathrm{e}$ $2,92 \mathrm{t} \mathrm{ha}^{-1}$, com uma média de 2,42 $\mathrm{tha}^{-1}$ e com coeficiente de variação de 
$13,60 \%$. Pode-se observar que os resultados de residuos vegetais presentes no solo estão em concordância com os baixos índices de cobertura.

Os atributos de densidade do solo e umidade no período que antecedeu a semeadura nas profundidades de 0 a 0,05 $\mathrm{m}$ e de 0,05 $\mathrm{m}$ a 0,10 m, são mostradas na Tabela 14. Observa-se que houve um incremento da densidade do solo com o aumento da profundidade.

Tabela 14. Resultados médios da densidade do solo e da umidade nas diferentes profundidades analisada, no periodo que antecedeu à semeadura para a área de Pirassununga, SP.

\begin{tabular}{|c|c|c|c|c|}
\hline \multicolumn{5}{|c|}{ Área Experimental de Pirassununga, SP } \\
\hline $\begin{array}{l}\text { Profundidade } \\
\text { (m) }\end{array}$ & $\begin{array}{c}\text { Densidade do solo } \\
\left(\mathrm{g} . \mathrm{cm}^{-3}\right)\end{array}$ & $\begin{array}{l}\text { C.V. } \\
(\%)\end{array}$ & $\begin{array}{c}\text { Umidade } \\
(\%)\end{array}$ & $\begin{array}{l}\text { C.V. } \\
(\%)\end{array}$ \\
\hline 0 a 0,05 & 1,14 & 10,42 & 19,30 & 34,88 \\
\hline 0,05 a 0,10 & 1,16 & 9,91 & 20,20 & 37,83 \\
\hline
\end{tabular}

No que se refere à compactação do solo, os resultados do índice de cone indicam niveis de compactação mais elevados entre as camadas de 0,25 m a 0,35 m, como pode-se observar no gráfico da resistência à penetração do solo (Figura 20). Considerando-se que a semeadura foi realizada na profundidade de 0,05 $\mathrm{m}$ aproximadamente, os niveis de compactação nas camadas mais profundas não deve ter afetado a germinação das sementes. 


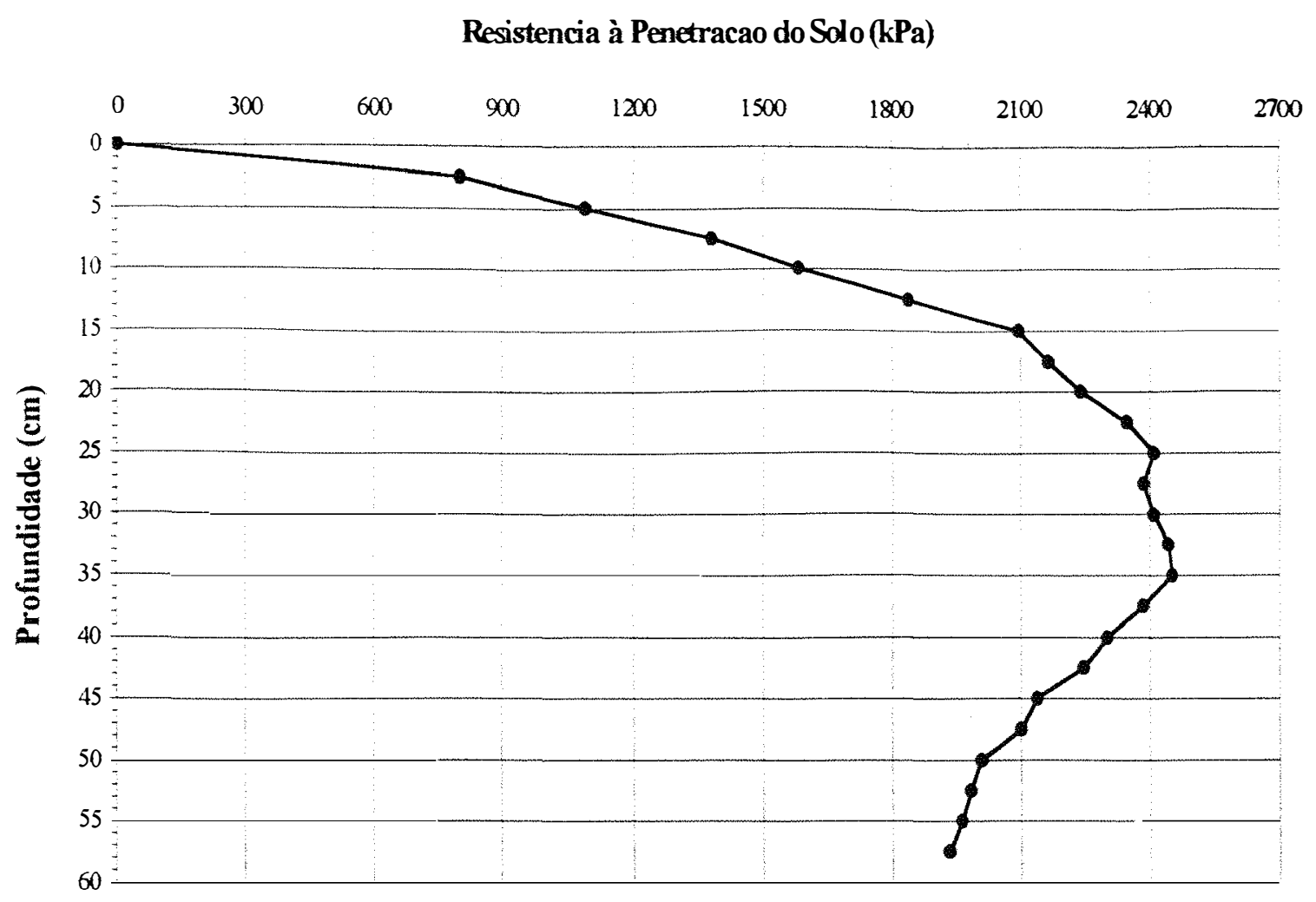

Figura 20 - Níveis de compactação do solo da área experimental de Pirassununga, SP; média das 36 amostras obtidas com penetrógrafo.

Na Tabela 15 são apresentados os resultados dos espaçamentos entre plantas para a área experimental de Pirassununga, como também uma sintese da análise de variância dos parâmetros utilizados para avaliar o desempenho das máquinas.

A análise estatística mostrou uma interação significativa para as porcentagens de espaçamentos normais, o que indica que as máquinas apresentaram um comportamento diferenciado dentro de cada velocidade de avanço. 
Tabela 15. Resultados dos ensaios da regularidade de distribuição longitudinal de plantas na área experimental de Pirassununga, SP.

\begin{tabular}{|c|c|c|c|c|}
\hline \multicolumn{5}{|c|}{ Múltiplos (\%) } \\
\hline \multirow[b]{2}{*}{ Máquinas ${ }^{1}$} & \multicolumn{3}{|c|}{ Velocidades } & \multirow[b]{2}{*}{ Média } \\
\hline & $1,5 \mathrm{~m} \mathrm{~s}^{-1}$ & $2,0 \mathrm{~m} \mathrm{~s}^{-1}$ & $2,5 \mathrm{~m} \mathrm{~s}^{-1}$ & \\
\hline Mq1 & 3,2 & 3,2 & 6,4 & 4,6 \\
\hline Mq2 & 3,6 & 3,2 & 5,7 & 4,2 \\
\hline $\mathrm{Mq3}$ & 4,6 & 4,6 & 9,6 & 6,3 \\
\hline $\operatorname{DMS}(\overline{0,05)}=$ & 0,570 & & $\operatorname{Pr}>\mathrm{F}(\%)=$ & 0,60509 \\
\hline \multicolumn{5}{|c|}{ Normais (\%) } \\
\hline \multicolumn{5}{|c|}{ Velocidades } \\
\hline Máquinas ${ }^{1}$ & $1,5 \mathrm{~m} \mathrm{~s}^{-1-}$ & $2,0 \mathrm{~m} \mathrm{~s}^{-1}$ & $2,5 \mathrm{~m} \mathrm{~s}^{-1}$ & Média \\
\hline$M q 1$ & $82,1 \mathrm{~A}$ & 88,9 a $A$ & $62,8 a b B$ & 77,9 \\
\hline Mq2 & 74,3 & $77,5 \mathrm{~b}$ & $71,4 a$ & 74,4 \\
\hline Mq3 & $83,2 \mathrm{~A}$ & $77,1 \mathrm{~b} \mathrm{~A}$ & $58,9 \mathrm{~b} \quad \mathrm{~B}$ & 73,1 \\
\hline $\operatorname{DMS}(0,05)=$ & 7,062 & & $\operatorname{Pr}>\mathrm{F}(\%)=$ & 0,00289 \\
\hline \multicolumn{5}{|c|}{ Falhas (\%) } \\
\hline \multicolumn{5}{|c|}{ Velocidades } \\
\hline Máquinas $^{1}$ & $1,5 \mathrm{~m} \mathrm{~s}^{-1}$ & $2,0 \mathrm{~m} \mathrm{~s}^{-1}$ & $2,5 \mathrm{~m} \mathrm{~s}^{-1}$ & Média \\
\hline$M q 1$ & $14,6 a b A$ & 7,9 a $A$ & $30,8 \quad B$ & 17,7 \\
\hline Mq2 & $22,1 \mathrm{~b}$ & 19,3 b & 22,9 & 21,4 \\
\hline $\mathrm{Mq} 3$ & 12,1 a $A$ & $18,2 \mathrm{~b} \mathrm{~A}$ & $31,4 \quad B$ & 20,6 \\
\hline $\operatorname{DMS}(0,05)=$ & 0,899 & & $\operatorname{Pr}>\mathrm{F}(\%)=$ & 0,00362 \\
\hline \multicolumn{5}{|c|}{ C.V. (\%) } \\
\hline \multicolumn{5}{|c|}{ Velocidades } \\
\hline Máquinas $^{1}$ & $1,5 \mathrm{~m} \mathrm{~s}^{-1}$ & $2,0 \mathrm{~m} \mathrm{~s}^{-1}$ & $2,5 \mathrm{~m} \mathrm{~s}^{-1}$ & Média \\
\hline$M q 1$ & $44,3 \quad B$ & 29,8 a $A$ & $56,2 a b C$ & 43,4 \\
\hline $\mathrm{Mq} 2$ & 47,1 & $45,6 \mathrm{~b}$ & $49,2 a$ & 47,3 \\
\hline $\mathrm{Mq} 3$ & $37,7 \quad A$ & 47,7 b A & 66,3 b $B$ & 50,6 \\
\hline $\operatorname{DMS}(0,05)=$ & 10,846 & & $\operatorname{Pr}>F(\%)=$ & 0,00036 \\
\hline \multicolumn{5}{|c|}{ Precisāo (\%) } \\
\hline \multicolumn{5}{|c|}{ Velocidades } \\
\hline Máquinas $^{1}$ & $1,5 \mathrm{~m} \mathrm{~s}^{-1}$ & $2,0 \mathrm{~m} \mathrm{~s}^{-1}$ & $2,5 \mathrm{~m} \mathrm{~s}^{-1}$ & Média \\
\hline Mq1 & 12,1 & 11,0 & 14,2 & $12,4 \mathrm{a}$ \\
\hline Mq2 & 14,2 & 12,3 & 15,5 & $14,0 a b$ \\
\hline $\mathrm{Mg} 3$ & 14,2 & 13,8 & 19,8 & $15,9 \mathrm{~b}$ \\
\hline $\mathrm{DMS}(0,05)=$ & 2,160 & & $P>F(\%)=$ & 0,32931 \\
\hline
\end{tabular}

Médias seguidas por letras distintas, maiúsculas na linha e minúsculas na coluna diferem entre si pelo teste de Tukey a 0,05 de significância. 
É possivel observar que na Mq1 as maiores porcentagens de normais foram registradas nas velocidades de $1,5 \mathrm{~m} \mathrm{~s}^{-1}$ e 2,0 $\mathrm{m} \mathrm{s}^{-1}$, com valores de 82,1 $\%$ e $88,9 \%$ respectivamente, as quais diferiram significativamente da última velocidade. Para a Mq2 não foi observada diferença entre os valores obtidos nas demais velocidades. Estes índices variaram na ordem de $77,3 \%$ e $71,4 \%$. $\mathrm{Na} \mathrm{Mq3}$, os melhores índice de normais foram obtidos também nas velocidades de $1,5 \mathrm{~m} \mathrm{~s}^{-1}$ e $2,0 \mathrm{~m} \mathrm{~s}^{-1}$, com porcentagens de $83,2 \%$ e $77,1 \%$ respetivamente, as quais diferiram significativamente da velocidade mais alta.

Comparando as máquinas entre si, verifica-se que na velocidade de 1,5 $\mathrm{m} \mathrm{s}^{-1}$ não foi observada diferença significativa entre as máquinas. Já na velocidade de 2,0 $\mathrm{m} \mathrm{s}^{-1}$, a Mq1 apresentou o melhor desempenho do ensaio, a qual diferiu significativamente das outras máquinas. Para a velocidade de 2,5 $\mathrm{m} \mathrm{s}^{-1}$ as Mq1 e Mq2, apresentaram as melhores porcentagens de espaçamentos normais, embora a Mq1 não tenha diferido significativamente da Mq 3.

Para os índices de múltiplos não foram observadas diferenças significativas, tanto entre máquina como entre velocidades. Pode-se dizer que - acréscimo da velocidade refletiu em um aumento das porcentagens de múltiplos para todas as máquinas. Estes índices de falhas variaram entre 3,2\% e $6,4 \%$.

No caso dos índices de falhas, a análise estatística mostrou ter uma interação significativa entre máquinas e velocidades. Analisando primeirio o fator velocidade dentro de cada máquina, observou-se tanto na Mq3 como na Mq1, os menores índice de falha, que foram obtidas nas velocidades de 1,5 m $\mathrm{s}^{-1}$ e $2,0 \mathrm{~m} \mathrm{~s}^{-1}$, com valores de $12,5 \%$ e $7,9 \%$ respetivamente e estas diferiram significativamente da última velocidade. No caso da Mq2 não foi observada diferença entre os resultados obtidos em cada velocidade. As mesmas estiveram entre $19,3 \%$ e $22,9 \%$.

Comparando as máquinas, pode-se observar que na velocidade de 1,5 $\mathrm{m} \mathrm{s}^{-1}$ as $\mathrm{Mq} 1$ e $\mathrm{Mq} 3$, apresentaram as menores porcentagens de falhas, embora 
a Mq1 não tenha diferido significativamente da Mq2. Já na velocidade de 2,0 m $\mathrm{s}^{-1}$, a Mq1 apresentou o menor índice de falha, diferindo estatísticamente das Mq2 e Mq3. Na última velocidade não foi registrada diferenças entre suas médias.

Também verificou-se um efeito significativo nos coeficientes de variação, tanto entre máquinas como nas velocidades. Analisando o comportamento da velocidade em cada máquina, observou-se um efeito significativo no caso da Mq1, onde o menor coeficiente de variação foi dado na velocidade de $2,0 \mathrm{~m} \mathrm{~s}^{-1}$ com uma porcentagem de $29,8 \%$, que diferiu significativamente das demais velocidades. $\mathrm{Na}$ Mq2 não foi observada diferença significativa e seus coeficientes variaram entre 45,6 \% e 49,2 \%. Já a Mq3 registrou um aumento significativo de seu coeficiente à medida que se aumentava a velocidade de $2,0 \mathrm{~m} \mathrm{~s}^{-1}$ para $2,5 \mathrm{~m} \mathrm{~s}^{-1}$.

Comparando o desempenho das máquinas entre si, pode-se dizer que na velocidade de $1,5 \mathrm{~m} \mathrm{~s}^{-1}$ não foram registradas diferenças significativas entre as mesmas. Já, à velocidade de $2,0 \mathrm{~m} \mathrm{~s}^{-1}$, a Mq1 apresentou o menor coeficiente de variação, diferindo significativamente das Mq2 e Mq3. Para a velocidade de trabalho de $2,5 \mathrm{~m} \mathrm{~s}^{-1}$ a Mq2 registrou o menor coeficiente de variação e diferiu significativamente da Mq3.

Não foram registradas diferenças significativas para os indices de precisão na interação máquina e velocidade. Embora, as Mq1 e Mq2 apresentaram as melhores médias de precisão, as quais estiveram na ordem de $12,4 \%$ e 14,0 \% respetivamente, apesar da Mq2 não ter diferido significativamente da Mq3. Cabe ressaltar que os melhores indices de precisão para cada máquina foram observados na velocidade de $2,0 \mathrm{~m} \mathrm{~s}^{-1}$. 


\subsection{Considerações práticas para futuros projetos visando a utilização comercial dessas máquinas.}

Os resultados dos ensaios de campo evidenciaram a necessidade de um melhor ajuste da posição do ponto de queda das sementes do mecanismo dosador para as ponteiras para cada combinação de velocidade. Este fato tornou-se mais evidente na Mq3 que teve seu desempenho significativamente influenciado pelo incremento da velocidade. As Mq2 e Mq3 tinham os mecanismos dosadores fixos o que limitava uma melhor sincronização com a rodas de ponteiras.

Para auxiliar na tarefa de ajuste da sincronização, pode-se sugerir para futuros trabalhos, a utilização de uma câmara de vídeo VHS. Mantovani et al. (1991), utilizaram uma câmara de vídeo VHS para registrar o comportamento de sementes quando eram ejetadas do mecanismo dosador. A metodologia adotada pelos autores demostrou ser apropriada para observar 0 comportamento da semente no momento de sua liberação. Tal técnica poderia ser adaptada para se determinar a melhor sincronização entre o mecanismo dosador e as ponteiras.

Seguindo a sugestão feita por Molin et al. (1998a), no caso da Mq1, com respeito ao sistema de fechamento e compactação das covas, foram feitas alterações no sistema. No entanto, ainda foram observadas dificuldades no fechamento das covas.

Ainda, para a Mq1, pode-se sugerir, para futuros projetos, uma roda compactadora mais próxima da roda de ponteiras já que as Mq2 e Mq3 apresentaram essa configuração e mostraram ser mais apropriadas para o fechamento e compactação das covas. Da mesma forma, o desenho da roda compactadora adotada pelas Mq2 e Mq3 pareceu ser melhor.

As Mq2 e Mq3 contavam com um sistema de suspensão por molas que permitiam-Ihes acompanhar melhor o relevo do solo, facilitando desta forma, 
também, a regulagem de profundidade de semeadura. A Mq1 não contava com esta vantagem, já que possuía uma estrutura fixa a qual dificultava notadamente a regulagem de profundidade, sobretudo em superfícies irregulares.

A Mq1 apresentou limitações na formação das covas em solo arenoso, já que a semente depositada era freqüentemente lançada para fora da cova. $O$ mesmo não acontecia com as outras máquinas, as quais tinham as ponteiras orientadas em sentido contrario ao da Mq1. Em futuros ajustes no projeto da Mq1 sugere-se adotar o desenho utilizado pelas Mq2 e Mq3. 


\section{CONCLUSÃO}

Com base nos resultados obtidos e nas condições em que foram realizados os ensaios, pode-se estabelecer as conclusões que se seguem:

Tanto em condições de laboratório como de campo, independente das áreas experimentais, a Mq1 obteve o melhor desempenho quanto à uniformidade de distribuição de sementes. Seus melhores resultados foram obtidos na velocidade de $2,0 \mathrm{~m} \mathrm{~s}^{-1}$.

Para as Mq2 e Mq3, apesar de apresentarem configurações semelhantes, a diferença no mecanismo dosador foi decısiva no desempenho, tanto em nível de laboratório como de campo.

A Mq2 apresentou o melhor desempenho nos ensaios de laboratório na velocidade de $2,5 \mathrm{~m} \mathrm{~s}^{-1}$. Nos ensaios de campo, o melhor desempenho foi registrado na velocidade de $2,0 \mathrm{~m} \mathrm{~s}^{-1}$.

$\mathrm{Na} \mathrm{Mq3,} \mathrm{o} \mathrm{melhor} \mathrm{desempenho} \mathrm{foi} \mathrm{observado} \mathrm{na} \mathrm{velocidade} \mathrm{de} 1,5 \mathrm{~m} \mathrm{~s}$ ${ }^{1}$, tanto nos ensaios de laboratório como de campo. De forma geral, o aumento da velocidade influenciou negativamente no desempenho da máquina para todas as variáveis referentes à uniformidade de distribuição.

O mecanismo dosador pneumático, pertencente à $M q 1$, foi o que apresentou menor dano mecânico à semente. A Mq3, com mecanismo dosador do tipo colher, foi a que apresentou os maiores índices de dano mecânico. 


\section{REFERÊNCIAS BIBLIOGRÁFICAS}

ADEGAS, F. S. Manejo integrado de plantas daninhas. In: CONFERÊNCIA ANUAL DE PLANTIO DIRETO, 2., Pato Branco, 1997. Anais. Passo Fundo: Aldeia Norte, 1997. p.17-33.

ADEKOYA, L. O; BUCHELE, W.F. A precision punch planter for use in tilled and untilled soils. Journal of Agricultural Engineering Research, Wageningen, v.37, p. 171-178. 1987.

ASAE. 1997. EP 291.2: Terminology and definitions for tillage and soil tool relationships. American Society of Agricultural Engineers.. p.117.

ASAE. 1993. EP 291.2. Terminology and definitions for soil tillage and soil-tool relationships.

BALASTREIRE, L.A. Máquinas agrícolas. São Paulo, SP: Manole, 1987. $307 p$.

BRASIL. Ministério da Agricultura e Reforma Agraria. Regras para análise de sementes. Brasília, 1992. 188p.

BERTONI, J., LOMBARDI NETO, F. Conservação do solo. São Paulo, SP: Ícone, 1990, $355 \mathrm{p}$. 
CHHINNAM, M.S.; YOUNG, J.H. e ROHRBACH, R.P. Acurracy of seed spacing in peanut planting. Transactions of the ASAE. 18(5): 828-831. 1975.

CHOUDHURY, M.S.U. Evaluation of manual planters for selected crops in West African Savana. Agricultural Mecanization in Asia, African and Latin America, 16 (4):25-9. 1985.

COBRA, A.P. Máquinas mais eficientes na semeadura direta. Dirigente Rural, São Paulo,1986. 23-25p.

COELHO, J.L.D. Avaliação de elementos sulcadores para semeadoras utilizadas en sistemas conservacionistas de manejo do solo. Campinas, 1999. 86p. Dissertação (M.S.) - Facultade de Engenheria Agrícola, Universidade Estadual de Campinas.

COELHO, J.L.D. Ensaios \& certificação das máquinas para a semeadura. In: MIALHE, L.G. Máquinas agrícolas ensaios \& certificação. Piracicaba: Shekinah, 1997. cap.11, p.551-570.

DAMBRÓS, R.N. Avaliação do desempenho de semeadoras de milho com diferentes mecanismos dosadores. Piracicaba, 1998. 86p. Dissertação (M.S.) - Escola Superior de Agricultura "Luiz de Queiroz", Universidade de São Paulo.

DEBICKI, I.W.; SHAW, L.N. Spade-punch planter for precision planting. Transactions of the ASAE. 39(4): 1259-1267. 1996. 
DELAFOSSE, R.M. Máquinas sembradoras de grano grueso, descripcion y uso. Santiago, Chile. Oficina Regional de la FAO para America Latina e el Caribe. $1986,48 p$.

DERPSCH, R.; ROTH, C.H.; SIDIRAS, N. et al. Controle da erosão no Paraná, Brasil: sistemas de cobertura do solo, plantio direto e preparo conservacionista do solo. Eschbirn : GTZ, 1991. 271p.

DERPSCH, R. Agricultura sustentável. In: SATURNINO, H.M.; LANDERS, J.N. (Ed.). O meio ambiente e o plantio direto. Brasilia: EMBRAPA-SPI, 1997. p. $29-48$.

EMBRAPA. Centro Nacional de Pesquisa do Trigo. Avaliação do desempenho de plantadoras diretas para culturas de verão. Passo Fundo, 1994. Não paginado. (Relatorio técnico).

EMBRAPA - EMPRESA BRASILEIRA DE PESQUISA AGROPECUÁRIA. Serviço Nacional de Levantamento e Conservação de Solos. Manual de métodos de análise e conservação de solos. Rio de Janeiro, 1979. v.1.

FANCELLI, A L.; FAVARIN, J.L. Realidade e perspectiva para o sistema de plantio direto no Estado de São Paulo. FANCELLI, A L. (Coord.). Plantio direto no Estado de São Paulo. Assis : FEALQ/ESALQ, 1989. P.15-34.

FERREIRA, M.F.; NEUJAHR, E.B.; DALLMEMYER, A.U.; SCHNEIDER, V. Coeficiente tecnológico de semeadoras para plantio direto. In: XXVII Congresso Brasileiro de Engenheira Agrícola. Poços de Caldas, M.G.,v.2, 1998. Anais. Poços de Caldas. 
FILHO, V. Actualização em plantio direto. In: FUNDAÇÃO CARGILL. Plantio direto no Brasil. Campinas, 1986. p.63-82.

FURLANI, C.E.A., LOPES, A., ABRAHÃO, F.Z., LEITE, M.A.S. Influência da velocidade da semeadora na cultura do milho (zea mays) em diferentes condições de preparo do solo (compact disc). In: CONGRESSO BRASILEIRO DE ENGENHARIA AGRÍCOLA, 28., Pelotas, R.S., 1999. Tendências e inovações: trabalho. SBEA/ALIA, 1996

GASSEN, D.N.; GASSEN, F.R. Plantio direto: o caminho do futuro. Passo Fundo: Aldeia Sul, 1996. 207p.

HEINEMANN, W. H. Jr.; J. W. CARY and A.E. DILWORTH. Experimental machines for autodibble planting. Transactions of the ASAE. 16(4): 656659, ASAE, St Joseph, MI. 1973.

HEZRONI, A., Y. ALPER, A. ANTLER and I. WOLF. Seeding directly through plastic mulch. Macharizantion of vegetable production. Acta Horticulturae. 187. p. 93-98. 1986.

INTERNATIONAL STANDARDIZATION ORGANIZATION. Sowing equipment. Test methods - Part 1: Single seed drills (precision drill). 1984. ISO $7256 / 1$.

JAFARI, J. V., FORNSTROM, K. J. A precision punch planter for sugar beets. Transactions of the ASAE. 15(3): 569-571. 1972.

JASA, P.J.; DICKEY, E.C. Tillage factors affecting corn seed spacing. Transactions of the ASAE. 25(6): 1516-1519. 1982 
KACHMAN, S. D., SMITH, J.A. Alternative measures of accuracy in plant sapcing for planters using single seed metering. Transactions of the ASAE. 38(2): 379-387. 1995.

KLUTHCOUSKI, J. Efeito de manejo em algumas atributos de um latossolo roxo sob cerrado e nas caracteristicas produtivas de milho, soja, arroz e feijão, após oito anos de plantio direto. Piracicaba, 1998. 179p. Tese (Dr.) - Escola Superior de Agricultura "Luiz de Queiroz", Universidade de São Paulo.

KURACHI, S.A.H.; COSTA, J.A.S.; BERNARDI, J.A. et. al. Avaliação tecnológica de semeadoras e/ou adubadoras: tratamento de dados de ensaios e regularidade de distribuição longitudinal de sementes. Bragantia, v. 48, n.2, p. 249-262, 1989.

LAFLEN, J.M., AMEMIYA, M., and HINTZ, A.E. Measuring crop residue cover. Jounar of soil and water conservation, v. 36, n. 6, p. 341-343. Nov./Dec. 1981.

LANDERS, J.N. Fascículo de experiências de plantio direto no cerrado. Goiânia, GO: Associação de Plantio Direto no Cerrado, Fundação Cargil. 1995. $261 p$.

LOPES DE OLIVEIRA, M. Avaliação do desempenho de semeadoras de milho com diferentes mecanismos dosadores. Viçosa, M.G., 1997. 50p. Dissertação (M.S.) - Universidade Federal de Viçosa.

LOMBARDI, F. Práticas conservacionistas em microbacias. In: MECANIZAÇÃO CONSERVACIONISTA - NOÇÕES BÁSICAS. Campinas: Especial SAA, Ano 1991. p.93-117. 
LUCIANO, M.A.; FORCELLINI, F.A.; WEISS, A.; BACK, N. Desenvolvimento de uma semeadora por cova acoplável a tratores de rabiças. In: XXVII Congresso Brasileiro de Engenheira Agrícola. Poços de Caldasção, M.G., v.2, 1998. Anais. Poços de Caldas.

MANTOVANI, E.C.; BERTAUX, S.; MANTOVANI, B.H.M Uso de câmara de vídeo VHS em bancada de teste para semeadoras. In: XX Congresso Brasileiro de Engenharia Agrícola. Londrina, PR., v.2, 1991. Anais. Londrina. s.ed, 1991. V2, p.1386.

MANTOVANI, E.C.; BERTAUX, S. Avaliação do desempenho de semeadoras adubadoras de milho no campo. Sete Lagoas: Embrapa-NPMSIABIMAQ SINDIMAQ, 1990. 49p.

MOLIN, J.P.; D'AGOSTINI, V. Develompment of a rolling punch planter for stony soil conditions. Agricultural Mechanization in Asia, Africa and Latin America, v.27, n.2, p.17-19, 1996.

MOLIN, J.P.; CHANG, C.S. Desenvolvimento e testes de dosador vertical para semeadoras de precisão. In: CONGRESSO BRASILEIRO DE ENGENHARIA AGRÍCOLA, 20., Londrina, 1991. Anais. Londrina: SBEA, 1991. p. 1667-1679.

MOLIN, J.P., BASHFORD, L.L., VON BARGEM, K. and LEVITICUS, L.I. Desingn and evaluation of a punch planter for no-till systems. Transactions of the ASAE. 41(2): 307-314. 1998a.

MOLIN, J.P. BASHFORD, L.L., GRISSO, R.D. and JONES, A.J. Population rate changes and other evolution parameters for a punch planter prototype. Transactions of the ASAE. 41(5): 1265-1270. 1998b. 
MONDARDO, A. Manejo e conservação do solo. In: FUNDAÇÃO CARGILL. Plantio direto no Brasil. Campinas, 1984. p.53-78.

MORRISON JUNIOR, J.E. No-tillage experimental planter performance and depth regulation evaluation. Transactions of the ASAE, p. 602-609, 1978.

MORRISON JUNIOR, J.E., GERIK, T.J. Planter deph control: II. Empirical testing and plant responses. Transactions of the ASAE, v. 28, n. 6, p. 1744-1748, 1985.

PASQUA, S.E.; MILAN, M.; PECHE, A. F. Controle de qualidade em operações agrícolas mecanizadas. In: CONGRESSO BRASILEIRO DE ENGENHARIA AGRÍCOLA, 25:; CONGRESSO LATINO AMERICANO DE INGENERIA AGRíCOLA, 2., Bauru, 1996. Anais, Bauru: SBEA/ALIA, 1996. /Resumo em CAB Abstract on CD-ROM, 1996.

PIMENTEL, F.G. Curso de estatística experimental. 12 ed. Piracicaba: Livraria Nobel, $1987.433 \mathrm{p}$.

PIMENTEL, M. Cerrados: A natureza agradece. Manchete Rural. A Revista do Agribusines, n. 135, p. $75-90,1988$.

PORTELLA, J.A.; SATTLER A.; FAGANELLO, A. Máquinas e implementos para Plantio Direto. CNPT, EMBRAPA, FUNDACEP, FECOTRIGO, ABC. Plantio Pireto no Basil. Passo Fundo - RS, 1993. p. 29-36.

PORTELLA, J. A., SATTLER, A., FAGANELLO. Regularidade de fertilizantes de semeadoras para plantio de trigo e soja. Engenharia Agrícola. Jaboticabal, 17 (4), p. 57 - 64,jun. 1998. 
SATTLER, A. Escolha de semeadoras e a importância dos elementos rompedores em plantio direto. In: I CONFERENCIA ANUAL DE PLANTIO DIRETO, 1996, Passo Fundo - RS. Resumos, Passo Fundo - RS: Editora, 1996. P. 13-16.

SCHULTZ; L.A. Técnicas e perpectivas: Manual de Plantio Direto. Porto Alegre - RS. 2 ed.1987, 124 p.

SHAW, L.N.; BRYAN, H.H. and WEST, S.H. Macharizantion of vegetable production. Acta Horticulturae. 187. p. 31-35. 1986.

SHAW, L.N.; KROMER, K.H. Revolving spade planter soil opener. ASAE. Paper No. 89-1504. St. Joseph, MI. 1987.

SHAW, L.N.; FLUCK, R.C. and BRYAN, H.H. Energy conservation by recropping plastic mulch covered tomato beeds. ASAE. Paper No. 78-1509. St. Joseph, MI. 1978.

SINGH, J.; MCMENNAMY, J.A and BRYAN, H.H. Evaluation of selected upland crops establishment techniques. Agriculture Mechanization in Asia 11(2): 11 6. 1980 .

TOURINO, M.C.; KLINGNSTEINER, P. Ensaio e avaliação de semeadoras adubadoras. In: CONGRESSO BRASILEIRO DE ENGENHARIA AGRíCOLA, 8, Rio de Janeiro, 1983. Anais. Rio de Janeiro: UFRRJ, 1983. v. 2 , p. $103-116$.

WILKINS, D.E.; ADRIAN, P.A.and. CLONEY, W.J. Punch planting of vegetable seeds - A progress report. Transactions of the ASAE. 22(3): 746-749. 1979. 
WILKINS, D.E.; MUILENBURG, G.A; ALLMARAS, R.R.; JOHNSON, C.E. Grain-drill opener effects on wheat emergence. Transactions of the ASAE. 26(3): 651-655, 660. 1983.

WIJEWARDENE, R. Energy-conserving farming systems for the humid tropic. Agricultural Mecanization in Asia, p. 47-53, 1980. 